\author{
UNIVERSIDADE DE SÃo PAULO \\ FACULdADE DE FILOSOFIA, LETRAS E CIÊNCIAS HuMANAS \\ DEPARTAMENTO DE FILOSOFIA \\ Programa de Pós-Graduação em Filosofia
}

\author{
Edson Querubini
}

\title{
Montaigne e a Arte da Conversação: a conversão para a "maneira"
}




\title{
Edson Querubini
}

\section{Montaigne e a Arte da Conversação: a conversão para a "maneira"}

\begin{abstract}
Dissertação apresentada ao programa de Pós-Graduação em Filosofia do Departamento de Filosofia da Faculdade de Filosofia, Letras e Ciências Humanas da Universidade de São Paulo, para obtenção do título de Mestre em Filosofia sob a orientação do Prof. Dr. Sérgio Cardoso.
\end{abstract}


"Plurimum proficit sermo..."

Sêneca, Epístulas Morais à Lucílio IV, 38 


\section{AgRAdecimentos}

Agradeço, muito especialmente, a Sérgio Cardoso, pela imensa confiança, paciência e generosidade com que me acolheu e pelo cuidado e atenção criteriosa com que orientou os meus estudos e a confecção desta dissertação.

A minha amada esposa e companheira Wanderleia, sem cujo amor, apoio, compreensão e dedicação eu não teria realizado este trabalho.

Ao Pedro, minha alegria.

Aos meus pais, pelo afeto e zelo essenciais com que me formaram.

A minha querida irmã, Cris, a quem devo mais do que ela mesma sabe, e ao meu caro cunhado Carlos, pelo sorriso e bom humor constantes.

Aos funcionários da secretaria do Departamento de Filosofia (Maria Helena, Mariê, Verônica, Geni, Luciana, Ruben e Roseli) pelo auxílio indispensável.

À CAPES, pelo apoio e financiamento.

À Profa. Dra. Maria das Graças de Souza e ao Prof. Dr. Luís César Guimarães Oliva, pelas argüições e pelo estímulo que contribuíram muito para a realização deste estudo.

À Profa. Dra. Marilena de Souza Chauí e à Profa. Dra. Telma de Souza Birchal: à primeira, pela justeza do perfil psicológico traçado depois de 15 minutos de convivência; a ambas, por ouvirem pacientemente os primeiros balbucios de um estudante.

Aos colegas e professores do Grupo de Estudos Renascentistas, pelos agradáveis encontros e proveitosas discussões.

A todos os amigos que conviveram e convivem comigo no Núcleo de Estudos de Línguas Estrangeiras, dentre os quais não posso deixar de destacar Sílvio Rosa, Anderson Gonçalves, Denilson Soares Cordeiro e Vicente de Arruda Sampaio, que sempre demonstraram especial consideração e amizade por mim. Ao amigo Daniel, pela gentileza em traduzir o resumo.

Ao caríssimo amigo André Scoralick, pelas 36 horas de conference sobre Aristóteles, a caminho de Salvador, e outras tantas ajudas. 


\section{Resumo}

QUERUBINI, E. Montaigne e a Arte da Conversação: a conversão para a "maneira". 2009. 130 f. Dissertação (Mestrado) - Faculdade de Filosofia, Letras e Ciências Humanas. Departamento de Filosofia, Universidade de São Paulo, São Paulo: 2009.

Esta dissertação apresenta uma análise da retomada e desenvolvimento do tema clássico da "conversação" (sermo) por parte de Michel de Montaigne em seu ensaio III VIII, De l'art de conferer. Examina-se, por um lado, como o Ensaísta estabelece, por oposição a duas contrafações, dissimulação e erística, o regime ideal da boa conference. Por outro lado, como, por oposição à inépcia contra-exemplar do tolo ("sot"), expõe as três qualidades da manière du dire: a "ordem", a "prudência", a "suffisance". Mostra-se, então, que esta reorientação para a "maneira", fazendo a crítica do artifício e do pedantismo - e seu saber aparente, apoiado apenas na memória -, funda-se no cuidado com as concepções e matérias, assimiladas pela experiência. A compreensão da conference, rival e cooperativa, entre amigos que discutem opiniões contraditórias e se corrigem mutuamente, faz dela o modo privilegiado de freqüentação e avaliação dos homens e dos livros, e o meio mais próprio do exercício do julgamento e do pensamento. Pautam-se neste percurso questões fundamentais para o tratamento do ensaio como forma.

Palavras-chave: arte da conversação, conference, maneira, ensaio, exercício do juízo 


\begin{abstract}
QueRUBINI, E. Montaige and the Art of Conversation: the conversion to "manner". 2009. 130 f. Thesis (Master degree) - Faculty of Philosophy, Languages and Human Sciences, Department of Filosophy, University of São Paulo, 2009.

This dissertation presents a analysis of the Montaigne's own development of the classical theme of "conversation" in his essay III VIII, De l'art de conferer. It is examined, on one hand, the way he sets up the ideal regime of good conversation by opposing it both to dissimulation and to eristic, both considered as counterfeits; on the other hand, how he defines, by opposing it to the counter-exemplary inneficiency of the foul ("sot"), the three caracteristics of the manière du dire: "order", "prudence" and "suffisance". Once criticized artifice and pedantry - whose apparent knowledge is only supported by memory -, it is shown that this reorientation to "manner" is founded over the diligence with the notions and subjects leaned by experience. The correct comprehension of the rival and cooperative conference, between friends discussing together conflicting opinions and correcting each other, makes of it the privileged way of frequenting and evaluating mens and books, and also the appropriate way of judgement's and thinking's exercise. Along with these, some questions involving the essay as a literary form are also treated.
\end{abstract}

Key-words: the art of conversation, conference, manner, essay, judgement's exercise. 


\section{SUMÁRIO}

Introdução

Capítulo 1 - A concepção montaigneana da conference

1.1. A "economia" da relação

1.2. A forma de conduta no debate: 0 imperativo da "ordem" 44

1.3. O dire prudemment e a jurisdiction interne

Capítulo 2 - O dire suffisamment 80

2.1. Suffisances $d^{\prime}$ apparences

81

2.2. Suffisances estrangeres 102

2.3. As "agudezas" e "ditos espirituosos" 112

2.4. O juízo sobre a própria obra 114

2.5. Epílogo: A leitura-conversa da História de Tácito

Considerações finais 120

Bibliografia 123 


\section{INTRODUÇÃO}

O objetivo deste trabalho é tão somente o de apresentar uma leitura e interpretação do capítulo sobre a Arte da conversação inserido no terceiro livro dos Ensaios $^{1}$ de Michel de Montaigne. Portanto, ele terá como eixo uma exposição que tentará percorrer os principais elementos de sua composição e tentará reconstituir os seus nexos internos. Apoiaremo-nos, na medida da necessidade, em outros textos de Montaigne para esclarecer certos desenvolvimentos $^{2}$. Não se recorrerá, porém, nesta tentativa de exposição dos liames internos pelos quais se articula este capítulo, a um esclarecimento proveniente das fontes de que depende o pensamento do filósofo. Não ignoramos a inscrição das idéias sobre a "conversação" em longa linhagem³. Simplesmente, nossa perspectiva (visto que só tomamos o presente trabalho como uma primeira abordagem do tratamento desta questão por Montaigne) será outra. Não nos interessam o tema e as idéias apresentadas sobre a "conversação" enquanto disciplina ligada à cortesania, e sim na medida em que, aproveitando um mote dado por Pierre Villey na nota que apõe ao capítulo em sua edição, em seu tratamento efetivo Montaigne "nos dá uma arte de conduzir seu pensamento" ${ }^{4}$. Pois, trata-se para nós antes de tudo de colher elementos, por assim dizer, internos à obra para pensar o estatuto de seu próprio discurso, o pertencimento, tantas vezes problematizado, deste discurso

\footnotetext{
${ }^{1}$ Todas as referências aos Ensaios serão feitas a partir da seguinte edição: MONTAIGNE, Michel de. Les Essais. Édition de Pierre Villey, sous la direction et avec préface de V.-L. Saulnier. Paris: PUF, 1999. 3 vol. (Col. Quadrige). O capítulo que iremos comentar, intitulado De l'art de conferer, ocupa as páginas 921 à 943 do terceiro volume.

${ }^{2}$ Lembremos, por agora, capítulos como o Du pedantisme (I xxv) e De l'institution des enfans (I xxvi), bem como o De trois commerces (III III), que acabam por tocar longamente em temas afins aos do De l'art de conferer.

${ }_{3}^{3}$ Pensamos na centralidade do gênero diálogo, e das epístolas, para a própria exposição do pensamento filosófico, desde Platão. Nem podemos nos esquecer do relevo e da importância do sermo para Cícero ou Sêneca, este último sendo um dos antigos de que mais se alimentou confessadamente nosso autor; ou do impacto dos tratados italianos, o Cortesão, de Baldassare Castiglione, e, sobretudo, A Conversação Civil, de Stefano Guazzo, sob cuja sombra todas as discussões sobre a cortesania e a conversação acabam se abrigando. Montaigne não se furta a estas aproximações, sendo notório, além disso, pela simples experiência de leitura, se não o fosse claramente afirmado, o caráter de conversa que imprime aos seus Ensaios, notadamente pelo traço de disposição e elocução negligenciadas que encontramos neles. Esta relação com a ordo neglectus e com o sermo humilis, já abundantemente notada pelo campo do comentário, e que tem relação com a composição do retrato natural dos Ensaios, acreditamos poder ser melhor examinada depois de explorarmos um outro aspecto da conversação, pois para nós ela está implicada na própria "forma de racionalidade" do ensaio.

${ }^{4}$ Cf. III VIII, De l'art de conferer, p. 921 - notícia introdutória.
} 
ao terreno da filosofia, sua relação com o exercício da dúvida, que dá a obra um viés eminentemente negativo e crítico, e o sentido de sua reorientação para a "maneira", tão importante para a compreensão do projeto montaigneano de retratar-se no livro. Este o foco de nossa exploração primeira: averiguar em que consiste esta "arte", cujas "regras" 5 são, segundo Montaigne, as do "são entendimento", inscrita na pré-história do método cartesiano e ao que parece tão avessa aos "métodos" artificiais, que são os das preceptivas retóricas e dialéticas do tempo, herdeiras mais ou menos tardias da tratadística antiga, e que tentam regular e regrar a produção do pensamento e do discurso que the dá expressão. E num segundo momento, mais adiante, buscar verificar $\mathrm{o}$ quanto estas considerações sobre a conversação nos permitem esclarecer e elucidar a própria conformação e configuração do discurso montaigneano nos Ensaios, pressupondo com isso que o ensaísta juntaria o que professa nele, com o que no todo da obra se pratica.

Ora, acreditamos que há de se perguntar o leitor pelo sentido desta restrição imposta ao trabalho, que, ao limitar-se a um corpus tão exíguo pouco mais de vinte páginas, na edição que empregamos, das 1116 de que se compõem os Ensaios -, acabaria por não poder oferecer uma perspectiva um pouco mais ampla para avaliar a obra e o pensamento do autor em seu conjunto. Ao que podemos responder, na tentativa de justificar o recorte, da seguinte forma. Primeiro, julgamos que a reflexão contida nestas poucas páginas nos proporciona acesso a um problema clássico já, entre os comentadores, e de razoável importância para a compreensão do conjunto: a saber, o problema da forma de exposição - o próprio ensaio - e da ordenação do pensamento do Ensaísta, que se apresenta numa forma manifestamente caprichosa em seu andamento, e povoada de desconcertantes "digressões". Nada mais natural, pareceu-nos, do que interrogar o capítulo que explicitamente tematiza a conversa, para pensar uma "forma" que se molda segundo as modulações de uma simples conversa. Depois, digamos que a prudência de respeitar os limites, mas também o todo, das considerações de Montaigne contidas em cada capítulo, vem sendo igualmente observada pelos

\footnotetext{
${ }^{5}$ Talvez fosse melhor dizer advertissements, como faz, modestamente, nosso autor (Cf. id. ibid., p. 936: "Voyci un autre advertissement [...]"), que assim parece querer se esquivar da rigidez e fixidez de regras que teriam aplicação universal.
} 
comentadores. Com efeito, como investidas de reflexão e pensamento que são cada um dos ensaios, os quais não dão garantias de seus "resultados" para além dos movimentos que os vêem nascer e que lhes dão sustentação garantias que são ainda mais abaladas ao notarmos que não só Montaigne efetivamente muda de opinião acerca de muitas questões ao longo dos Ensaios, como ainda explicitamente admite essas variações em suas opiniões em muitas passagens -, não podemos exigir deles que componham em seu conjunto um todo acabado e perfeitamente coerente - sistemático, dir-se-ia -, senão ao preço do apagamento de muitos de seus traços essenciais, e mesmo talvez do maior a que se entrega nosso autor: a inconstância e a irresolução ${ }^{6}$. No entanto, tal irresolução não nos parece pertinente para pensar os mesmos movimentos de pensamento encerrados nos limites de um capítulo. Bem ao contrário, Montaigne nos parece bem seguro de seus passos, ainda que não premedite certamente aonde quer chegar. Não nos parece adequado projetar no plano interno dos capítulos esta irresolução, apoiando-se no fato de sua aparente desordem, que antes precisa ser entendida e interpretada. A isto, aliás, talvez a Arte da Conversação se preste bem, já que aí Montaigne da central relevo à questão da "ordem" e "pertinência" no curso de um debate ${ }^{7}$. Por fim, é preciso enfatizar que não nos obrigaremos a um confinamento estrito às fronteiras de um só capítulo, mas tomaremos a liberdade de transitar pelos capítulos restantes e interrogá-los na medida em que os mesmos temas e problemas sejam abordados e ajudem a esclarecer pontos em que as formulações, muitas vezes por sua brevidade, impõem dificuldades à interpretação. Apesar da enorme variedade e mesmo contradição que observamos ao longo da obra, não se pode deixar de notar constantes que a atravessam e em que podemos balizar nossas alegações sobre outros passos difíceis do texto.

\footnotetext{
${ }^{6}$ Será preciso avaliar o sentido e o alcance do exercício da dúvida - cética - nos Ensaios e da adesão de Montaigne às proposições a que chega, e mesmo as de que parte, em seus exercícios de julgamento. Contamos, hoje, com trabalhos importantes neste sentido, como particularmente o de GIOCANTI, S. Penser l'irresolution - Montaigne, Pascal, La Mothe le Vayer, trois itinéraires sceptiques. Paris: Honoré Champion, 2001.

7 Chegou-se mesmo a afirmar sem receios que se trata de um "discurso do método" montaigneano, que, no entanto, guarda pouca relação com o que será o cartesiano (Cf. o prefácio, intitulado "O discurso do método de Montaigne", de Marc Fumaroli a PASCAL, B. A arte de Persuadir precedida de A Arte da Conferência de Montaigne. São Paulo: Martins Fontes, 2004).
} 
Devemos observar que não deixa de ser árdua esta tarefa de reconstituição dos nexos argumentativos do discurso de Montaigne, embora restrita a um corpus pequeno de textos. Isto se deve, principalmente, a um traço característico dos arrazoados de nosso autor, que tem merecido grande atenção por parte do comentário. Trata-se da ordem irregular ${ }^{8}$ em que o texto se apresenta, ou seja, do caráter descosido dos segmentos do texto e de sua liberdade de exposição e tratamento das matérias, muitas vezes digressivos ou tomados por um viés inusitado, para não falar nos acréscimos, suscitados pela leitura que Montaigne faz da própria obra, que muitas vezes infletem o pensamento primeiramente exposto, dando-Ihe novo sentido. Teremos de voltar a este traço característico do discurso montaigneano e nele nos deter. Diga-se, por enquanto, somente que estas disposições insólitas e desordenadas do discurso, causam maior espécie num texto, tal como o que abordaremos, pois precisamente nos informa ele que a ordre é um dos primeiros e mais fundamentais traços dos esprits aptos para a conversa. De fato, esta noção que Montaigne prende, como veremos, sobretudo à pertinência e ao "propósito" das alegações que tecem a troca verbal entre os interlocutores na conversação, é um dos pilares de sustentação da manière $d u$ dire a que o capítulo se consagra. Ora, como assumimos, ao menos provisoriamente, que esta mesma ordre exigida para a conversa possa ser projetada no discurso que a expõe como regra e boa maneira, tentaremos, assim, reconstituir o movimento de pensamento que nele se desenha, a fim de elucidá-la, para que, depois, nela nos apoiemos para compreender, ao menos em parte, aquela mesma disposição inusitada.

Contudo, a ordre não esgota o tratamento dado ao assunto no De l'art de conferer. Outras duas importantes noções comparecem nele e servem de apoio para a exposição da séance da conversação, constituindo-se, por assim dizer, nas balizas que apóiam o exercício do pensamento e da razão em Montaigne. É acerca das próprias operações do ingenium montaigneano, em sua inventividade e capacidade de "julgamento", que elas nos instruirão. São elas: a prudence e a suffisance. Se a primeira nos permite pensar a dispositio -

\footnotetext{
${ }^{8}$ Para o problema da ordem irregular dos Ensaios, v. Tournon, A. La Glose et l'essai. Chap. III: "L'ordre irregulier des Essais". Paris: Honoré Champion, 2000, p. 105-41.
} 
não sem aproximar também esta noção da mesma inventividade - do discurso montaigneano, estas outras nos ajudarão a pensar a sua própria invenção ${ }^{9}$.

É a toda uma relação com a cultura que a noção de suffisance nos envia. O exame dela, com efeito, nos remeterá, primeiro, a uma crítica dos juízos formulados a partir da nossa primeira apreensão das coisas pelos sentidos, crítica que visa igualar os homens de "condições" diferentes e permitir o estabelecimento da conversação, para, em seguida, passar a uma discussão sobre o "próprio" e o "alheio" na constituição do pensamento e do discurso. Poderemos, assim, abordar a questão dos empréstimos e furtos e do tratamento da herança legada pela tradição. No limite, o que Montaigne estabelece é um critério para medir a estatura e o valor de uma "alma", a partir da relação que mantém com os saberes, e da correlata autoridade neles depositada $^{10}$, operação de medida, aliás, assinalada, segundo pensamos, como fim último à própria conversação. Basta lembrar o ambiente de erudição livresca em que está mergulhada a cultura humanista do tempo para percebermos a importância de se discutir critérios que permitam discernir os homens que, realmente imbuídos do espírito da instrução recebida das grandes almas da antiguidade, souberam fazer suas estas lições e até levá-las adiante - as "testes bien faictes" de Montaigne -, de outros que não fazem senão repeti-la, sem, de fato, tê-la digerido. Para além da crítica à escola e ao

\footnotetext{
${ }^{9}$ Se recorremos a um vocabulário técnico e conceitual da retórica (disposição, invenção, elocução etc.) é porque o encontramos inscrito no próprio discurso de nosso autor. Montaigne pensa com estas categorias sua própria obra e as dos outros, embora insista bastante em dizer que compõe sua obra sem nenhuma arte. A conversação não escapa a esta conceituação a partir das artes que regulam a produção de discursos. Também o trânsito entre aptidão para a conversação e produção da obra escrita é autorizado pelo discurso montaigneano, que mescla estas discussões tornando-as quase indiscerníveis. Quanto ao problema específico da disposição, veremos que, no que concerne à conversação, e isto em grande medida vale para os Ensaios, não há uma ordem prévia que deva ser respeitada para a confecção do discurso, ou seja, ambos não respeitam um plano tipo tal como o dos discursos da prosa oratória (proêmio, narração, confirmação, refutação, peroração). O que prende um arrazoado a outro numa seqüência congruente é a pertinência das alegações, portanto, a disposição depende de um desenvolvimento cujo foco é dado pelas próprias matérias tratadas e pelo vínculo que guardam entre si. Disso resulta o aspecto negligenciado da disposição nas conversações, em que mal reconhecemos claras divisões, e em que os arrazoados parecem progredir como que ao acaso, ou melhor, respeitando apenas o nexo interno que liga os enunciados uns aos outros. O problema de saber se no caso específico dos Ensaios há um esforço de afetar esta negligência ao produzir seus escritos, isto é, se emprega arte em ocultar seus próprios procedimentos, só poderá ser discutido posteriormente.

${ }_{10}$ Montaigne discute, igualmente, a relevância política desse reconhecimento do verdadeiro valor dos esprits que a conversação pode propiciar, ao tocar no problema da escolha do conselho pelos príncipes, como veremos. O homem de boa conversação não se dissocia, também para Montaigne, da figura do amigo que abertamente admoesta, em âmbito privado, mas que não se furta a aconselhar francamente o príncipe.
} 
pedantismo em sua exterioridade e venalidade em relação ao saber, é o problema da autonomia do pensamento frente às suas fontes que assim se esboça, e de sua invenção, sempre imbricada, pois alimentada e suscitada pela relação com o pensamento alheio, mormente o antigo, que o tempo histórico de Montaigne assumiu dever recuperar e reavivar.

A própria noção de prudence não deixa de servir de ilustração sobre o difícil e arriscado emprego do discurso por meio do qual se tenta corrigir as opiniões e orientar as condutas, seja no âmbito privado, seja no público, no mundo humano incerto e oscilante que nos descreve Montaigne. Por advertir, entre outras coisas, sobre a possibilidade de se voltarem, em matérias controvertidas $^{11}$, nossas armas - diga-se, "argumentos" - contra nós, parece igualmente operar na seleção e escolha do que dirá o interlocutor apto e proficiente para a conversação, interferindo diretamente no andamento da conversação. Enfim, é sobretudo nas operações inventivas e seletivas do jugement que iremos atentar ao longo deste estudo do De l'art de conferer.

Assim, já pela questão da ordre que nestas discussões aflora, já pela da prudence e suffisance, estas considerações sobre a conversação consistem, ao nosso ver, em passo privilegiado e indispensável para entrar no universo das reflexões morais e políticas que no livro são expostas e, sobretudo, para compreender temas como o da manière, de que de algum modo teremos de falar, o do "retrato" e, principalmente, o do próprio estatuto do ensaio, principal contribuição que nos deixou Montaigne.

Passemos, então, a uma proposta de divisão do De l'art de conferer e a um resumo de suas partes.

\footnotetext{
${ }^{11} \mathrm{E}$ todas as matérias, diga-se, em Montaigne são, em princípio, controvertidas, i.e. sobre todas as coisas pode-se sustentar tanto o pró como o contra, pode-se disputar in utramque partem. Em verdade, esta dýnamis antilógica, aprendida e tomada, em grande parte, ao ceticismo, embora não sendo exclusividade sua, não nos parece dar conta de todos os exames e investigações presentes nos Ensaios. É evidente que a relação com o ceticismo se estreita, sobretudo a partir da Apologia de Raymond Sebond, mas pensamos que a orientação cética, ao constituir com suas argumentações obstáculos intransponíveis para o conhecimento das coisas, constitui para Montaigne apenas um "solo" para suas explorações práticas. Por isso, neste trabalho, longe de querer insistir na vertente puramente crítica do pensamento de Montaigne, gostaríamos de atentar, desviando-nos da crítica "epistemológica", para os ensaios do julgamento em seu imbricamento com o problema moral.
} 
Vale lembrar que a partição ${ }^{12}$ e o resumo da discussão que se propõem aqui não têm por fim senão evidenciar a consistência do ensaio III VIII no tratamento do tema da conference, mas não deixa de ser - temos consciência disso - uma traição da forma de exposição, na medida mesma em que nega o movimento ondulante do pensamento do Ensaísta, para tentar captar-Ihe o fio e a ordenação interna. Como se sabe, nem sempre são claros, pela própria natureza do ensaio, os pontos de corte nos textos. O arrazoado freqüentemente mescla as discussões, permite-se desviar, avança e por vezes retorna às questões que imaginávamos já ter ficado para trás, o que ocorre muito acentuadamente na prática montaigneana do gênero. Avisados, pois, desta característica e, portanto, da possibilidade de alguns deslizamentos da divisão, procederemos a uma partição do que, para nós são seus grandes movimentos argumentativos. Depois, antes da glosa e do cometário propriamente ditos, passaremos a um resumo do que é proposto em cada parte, para melhor orientação do leitor.

Em suas grandes linhas o De l'art de conferer consta de um exórdio ${ }^{13}$ (§§ 1-4, p. 921-22), de um grande desenvolvimento (§§ 5-49, p. 92240), e de um epílogo (§§ 50-54, p. 940-43). O desenvolvimento divido-o em 2 partes, sendo que a segunda, bem maior, é sub-dividida em 3 outras, que comportarão outras divisões internas. Num primeiro movimento - a parte inicial e menor do desenvolvimento (§§ 5-12, p. 923-25) -, discutem-se as primeiras condições para o estabelecimento da conversação e a "economia" desta relação. No seguinte, bem maior, a discussão se reorienta para o problema da manière e os "modos do dizer" (§§ 13-49, p. 925-940). A primeira sub-parte

\footnotetext{
${ }^{12}$ Para uma divisão alternativa do texto, embora coincidente em alguns pontos de articulação, veja-se o artigo de Yves Delegue, "De l'art de conferer (III-8) ou de la sottise" (In BSAM, VIII' Série, no. 29-30, Janvier-Juin 2003).

${ }^{13}$ A numeração dos parágrafos, que farei acompanhar da numeração de páginas, intenta somente tornar mais cômoda esta divisão. A edição que empregamos adota uma paragrafação não numerada que não se encontra nas edições originais dos Ensaios. Ela depende do arbítrio do editor. Os exemplares da época de que dispomos, e principalmente o chamado exemplar de Bordeaux, que serviu de base para o estabelecimento das edições modernas, não apresenta parágrafos, constituindo-se cada capítulo de um bloco contínuo de texto, interrompido apenas pelas citações em verso de autores, a maioria latinos. Contudo, não encontramos nenhuma dificuldade em encontrar pontos de corte para nossa divisão maior do texto em locais que coincidem com as quebras estabelecidas pelos parágrafos de Villey. Logo, optamos por endossá-la nesta divisão maior, porém, com a liberdade de não segui-la no interior de cada movimento, quando os cortes, a nosso ver, apresentaram problema para a interpretação.
} 
deste novo passo discute o problema da "ordem" (§§ 13-21, p. 925-28), e contém uma "digressão" interna, em que se critica a relação dos homens com a ciência (§§ 17-18, p. 926-27). Segue-se a segunda sub-parte com uma discussão mais breve sobre a "prudência" (§§ 22-23, p. 928-30). Depois, entramos na terceira e mais longa sub-parte (§§ 24-49, p. 930-40), que aborda a suffisance do interlocutor, comportando esta, por sua vez, uma quádrupla divisão: o primeiro momento (§§ 24-38, p. 930-36), um longo ataque às suffisances d'apparences; o segundo (§§ 39-43, p. 936-38), advertências sobre como reconhecer as suffisances estrangeres; o terceiro (§§ 44-45, p. 938-39), breve menção e consideração das "agudezas"; o quarto e último (§§ 46-49, p. 939-40), as últimas considerações sobre como avaliar, na conversa, o valor do interlocutor. O texto se fecha, então, com um longo ajuizado sobre a "História de Tácito" (§§ 50-54, p. 940-43). Outras divisões menores, quando necessárias, serão feitas ao longo da explanação.

Feita nossa divisão, passemos a um resumo, só para que fiquem claros os pontos de articulação e o próprio andamento do texto.

A - Exórdio: sentido geral do ensaio [§§ 1-4, p. 921-22]

No exórdio Montaigne estabelece o estatuto da exposição sobre a "arte da conversação" que se seguirá. Por ele ficamos sabendo que 1) 0 tratamento que se dará ao tema da conference e ao problema dos "modos", da manière du dire, se fará não pela exposição das "virtudes", mas dos "vícios". E que 2) se o discurso conjunto que produzem os interlocutores apresenta "vícios" estes são antes devidos à má qualidade das "alegações" das partes, e estas resultam, em última análise, da "inépcia" dos próprios interlocutores. Em outros termos, Montaigne não trata as qualidades do discurso entretecido na conversa enquanto tal, e sim as qualidades, ou antes, defeitos, dos interlocutores que o entretecem. E este tratamento negativo ocorre em dois planos ao menos: por um lado, acusa um vício em que sói ele mesmo incorrer ao se deparar com um "tolo"; por outro, acusa os vícios da própria tolice.

Com efeito, o exórdio se divide em duas partes. $\mathrm{Na}$ primeira, Montaigne nos diz que, da mesma forma que uma certa concepção humana de justiça instrumentaliza suas execuções para advertência dos vivos, ele se 
"enforcará" trazendo a público e exibindo um erro que encontra em si mesmo (ele não suporta conversar com um tolo) em benefício dos outros homens que, assim, aprenderão a evitar tal erro. Na segunda, alega que, por sua própria "compleição", aprende mais por evitar os erros que encontra nos outros do que por imitar os acertos, já que, segundo ele, o espetáculo do vício, sobre ser mais comum, fere, e com isso "toca e desperta" mais.

Assim, vemos como já nos instrui nesta introdução sobre os dois planos de desenvolvimento da temática da "maneira" no capítulo: a exposição da imagem da tolice e a exposição de uma outra espécie de tolice, dele próprio esta, o irritar-se com o tolo.

B - Desenvolvimento [§§ 5-49, p. 922-40]

B (i) - A economia da relação na conference [§§ 5-12, p. 923-25]

O primeiro passo do desenvolvimento se ocupa em descrever a economia da relação que Montaigne elege para a conference e a postura conveniente dos interlocutores, tanto em suas respectivas relações com as matérias e opiniões diversas acerca delas, quanto em relação uns aos outros.

Uma primeira oposição estabelece a superioridade da conversa sobre o estudo dos livros, porque aquela conjuga "instrução e exercício", diferentemente da outra que apenas administra lições de autoridade, sem fazer conta de uma postura ativa. A conversa é melhor porque mantém desperto e ativo o pensamento com as contradições e objeções do interlocutor, obrigando ao exercício do entendimento e do julgamento. No entanto, isto só ocorre se os interlocutores não forem "obstinados" ("opiniastres"), pois estes apegam-se demasiadamente às suas próprias opiniões de tal modo que não aceitam a contradição, e incorrem em "cólera" quando são contrariados. De dois modos: ou porque deparam-se com oposições às suas opiniões, ou porque encontram quem se recuse acolher suas correções. Montaigne mobiliza aí o ceticismo e sua suspensão como solo em que funda a aptidão para a conversa. A partir da perspectiva da não apreensão (akatalepsia), iguala e nivela todas as "representações" ("fantasies"), sejam elas "conjecturas de uma velha", superstições, ou as mais sofisticadas e sustentadas proposições das filosofias 
dogmáticas. Com isso, os critérios de distinção entre os "esprits" necessariamente migram para o plano da manière.

Uma outra oposição, mas agora dupla, contrasta três espécies de conversa, assentada em três espécies de interlocutor e no tratamento mútuo que dispensam uns aos outros: Montaigne aplica o tópos da mediania para descrever a conference como o justo meio, que tem por extremos duas "contrafações": de um lado, o combate erístico, de outro, a adulação. Assim, a conversa proveitosa e agradável é descrita como relação privada entre amigos, que corajosa e generosamente se corrigem e repreendem, conservando a "verdade" como "causa comum" e procedendo a um exame de que se exclui toda mobilidade e afecção ligada ao páthos colérico, bem como toda vontade excessiva de impor uma opinião como evidente e certa, obtendo a vitória. As partes se despem de todo interesse por suas "teses" em nome da adesão à racionalidade pura no exame das "matérias", racionalidade que opera pelo trabalho e exercício das "contradições dos julgamentos".

Os erísticos, ao contrário, em sua temeridade, aderem obstinadamente não à "causa comum" da verdade, mas às suas próprias teses, e contradizem somente em vista da contradição ou no interesse de obter a vitória na disputa, a qualquer custo. Já os aduladores, em seu temor, não contradizem, mas concordam, também de maneira interessada, buscando, em sua dissimulação, lograr proveito. Podemos dizer que ambas atitudes diferem, não na "capacidade", mas na intenção, da postura exigida para o "conferencista", diferentemente do que ocorrerá com o "tolo", que falha, ele, pela falta de "capacidade".

É preciso ainda destacar que a "atitude apta" descrita não se confunde com uma força e capacidade tais que seriam capazes de triunfar do adversário a cada vez. Montaigne a descreve da perspectiva do "fraco", que busca corrigir-se. Por não presumir saber algo certo (mais uma vez o ceticismo operando), elege a companhia, amável e rude ao mesmo tempo, dos que repreendem e corrigem, e pode afirmar a superioridade - relativamente ao triunfo no embate da conference - da vitória que obtém sobre si quando cede à força da razão de seu adversário.

Como se vê por essas primeiras disposições, o Ensaísta trata a economia da conference segundo um duplo eixo: o da relação dos 
interlocutores com as coisas (eixo objetivo); o da relação dos interlocutores entre si (eixo intersubjetivo).

B (ii) - A manière du dire [§§ 13-49, p. 925-940]

Este desenvolvimento comporta 3 partes, delimitadas e separadas pelo tratamento dos 3 modos do "dizer" que integram as qualidades da "maneira", em cujo terreno fomos lançados: a) ordem; b) prudência e c) suffisance. O texto, obviamente, não nos oferece a "teoria" destas qualidades, nem nos homens, nem nos discursos que compõem conjuntamente, mas, no caso da ordem e da prudência, uma "imagem" do avesso delas, através dos defeitos que se encontram, respectivamente, no "tolo" e no próprio Montaigne que se irrita ao enfrentá-lo. Já no caso da suffisance, nos traz advertências sobre como reconhecer os que dela carecem.

Fica em segundo plano o jogo de oposições entre o "conferencista" e as duas contrafações apresentadas anteriormente (erístico e adulador) e assoma uma nova figura: o "tolo". A oposição tem agora apenas dois pólos e dá-se inteiramente no plano da "maneira". O que está em questão é a boa condução da busca, por isso é preciso avaliar se o interlocutor sabe se portar ou não. É para este ponto que se voltam as advertências, e a arte da conversação acaba assumindo o viés de arte de "pesar", e mesmo pôr à prova, os homens, através sempre de sua maneira e comportamento ao conversar e debater.

a) o imperativo da "ordem" [§§ 13-21, p. 925-28]

O dire ordonnéement é o primeiro dos "modos" ou qualidades do dizer, discutidos pelo capítulo. Montaigne apresenta ao longo deste movimento uma queixa e acusação da "desordem" do tolo, e faz um "diagnóstico" das suas causas. È no pedantismo dos sçavans que encontra o principal motivo da tolice. Paralelamente, semeia a expressão de sua irritação e impaciência, de onde extrairá a desculpa para desviar-se do tratamento das matérias e voltarse à discussão dos meios, bem como esclarecer e fundamentar o próprio sentido que a conference assume para ele, dado o solo cético pirrônico de que partira: o que está em causa é a boa e bela condução da busca, não a posse da verdade, ou seja, a conduta "ordenada e prudente" de um homme suffisant. 
Veremos como a "ordem" assenta na atenção ao assunto tratado e às matérias, por meio das respostas que Montaigne qualifica pela expressão "à propos". Deste modo, quando acreditávamos que o tratamento desviaria nossa atenção para o domínio da pura forma, ou da lógica, somos de novo reenviados ao cuidado com as matérias e a uma negação correlata de toda regra artificial na condução do pensamento. È, no entanto, mais a imagem negativa da desordem presente nas múltiplas faces da tolice que nos indicará o que é a ordem garantida pelos "meios naturais" de um "são entendimento". Pois, na fraqueza das concepções do tolo e no seu cuidado com a pura forma, frutos de uma relação errada com os saberes e servil com as letras, nosso autor encontra a principal causa de seu tumulto e desregramento.

b) o dire prudemment e a jurisdiction interne [§§ 22-23, p. 928-30]

Montaigne, neste passo, sofre o revés de uma auto-acusação de sua consciência, premeditada e anunciada desde o início, devido à sua irritação diante da tolice. Ele não se obstina, mas aceita a acusação e não a refuta, pois, reconhece o erro e a tolice de deixar-se levar pela própria "impertinência" do comportamento tolo, assumindo ele mesmo uma atitude vergonhosa.

Aproveita a oportunidade para discutir brevemente a prudência que se deve ter ao debater: como as matérias são controvertidas, sempre resta a possibilidade de que as armas empregadas se voltem contra nós. O que o modo da "prudência" ensina é, sobretudo, a avaliar, na disputa, as posições respectivas, suas e do adversário, e prever seus pontos fracos e fortes, sabendo guardar-se de conceder e aceitar certas formulações que abrem o flanco para o revide e a refutação. Diante do risco e da cegueira para os próprios erros, poder-se-ia pensar que melhor seria abster-se de repreender e corrigir, abster-se de conferer. No entanto, repõe-se a necessidade da correção, dever de caridade, acompanhada agora de uma inspeção interna da própria consciência, a jurisdiction interne, que o adverte para a possibilidade de que o erro, observado e repreendido nos outros, eventualmente encontra-se também nele. Reconhecendo e cedendo, dá mostras de ordem e boa conduta.

c) o dire suffisamment [§§ 24-49, p. 930-40]

Primeiramente, o Ensaísta se dedica a advertir seu leitor sobre o erro de julgar um homem como suffisant, levando em conta apenas a aparência externa que nos é comunicada pelos sentidos. Daí denuncia a dupla tirania, 
dos que falam ou comandam, e a aparência enganosa de capacidade e habilidade dos que assumem cargos, funções, comissões, cátedras, etc. Argumenta que a fortuna distribui estas honras públicas, e que não são obtidos por verdadeiro mérito. Sua advertência visa rebaixá-los de sua posição para o nível da conversação comum, visto que assim, igualados, pode-se avaliar-lhes a vis (força e capacidade).

Em seguida, expõe procedimentos para a conference com aqueles que avançam boas "considerações", sem que se saiba se eles as compreendem de fato, ou se apenas tomam-nas de empréstimo e conservamnas na memória. A avaliação passa da aparência exterior para o, por assim dizer, "mobiliário" interno dos interlocutores.

Mescla, então, uma brevíssima consideração sobre o uso dos "dizeres agudos e cortantes" e de seu interesse para a disciplina de correção mútua. Veremos o proveito e o deleite de mesclar riso e ironia visando tocar e corrigir os erros do amigo, sem ofender.

As últimas observações de Montaigne sobre a avaliação da suffisance voltam-se para a capacidade que cada um demonstra para julgar e discernir as qualidades da própria obra.

C - Epílogo: exercício de juízo e de conference com Tácito [§§ 5054 , p. 940-43]

Deixemos o comentário do sentido deste último movimento do texto para o final do nosso percurso de análise. 


\section{CAPÍTULO 1 - A concepção montaigneana da conference}

No primeiro passo do texto, que lhe serve de introdução e já lhe imprime e marca a orientação moral, somos remetidos a uma justiça que tem por princípio a exibição, acusação e condenação públicas dos erros de alguém, visando incutir temor nos outros que, deste modo, não cometeriam a mesma falta ${ }^{14}$. Inscrita, como nos diz o ensaísta, em sua própria "compleição", ele que também assim se instrui e corrige, tal disciplina orienta-se pela contrariedade e pela "fuga", e difere de outras que proporiam modelos para a imitação dos homens, exemplos para serem seguidos. O "princípio" que, por assim dizer, sustenta esta orientação é expresso algumas linhas adiante: "[B] [...] Ce qui poind, touche et esveille mieux que ce qui plaist" (III VIII, p. 922). E o texto demora-se um pouco ainda em glosá-lo ao retomar a tópica que acusa o presente como tempo de vícios e deterioração, que nos emendaria "par disconvenance plus que par accord, par difference que par similitude" (id. ibid.). Assim enunciada e, ainda que não se tenha até aqui introduzido o tema da conversação propriamente dita, esta máxima ${ }^{15}$ assinala o teor geral de correção mútua que Montaigne irá reclamar para ela, já prenunciando dois pontos que serão desenvolvidos logo num primeiro momento: a necessidade da repreensão corajosa por "contradição" como conduta "correta" entre os pares que se põem a debater e o ataque que se fará de toda conversa em que, ora um interlocutor reclama excessiva autoridade para sua opinião, ora ambos descambam para a adulação e dissimulação, impedimentos do curso da boa discussão que o texto terá de atacar e desautorizar.

De um ponto de vista mais geral, duas exigências para a "conference" se exprimirão e articularão no texto: uma é recolhida na máxima que recomenda a instrução por "contrariedade"16; a outra é construída na

\footnotetext{
${ }^{14} \mathrm{O}$ deslocamento observado nesta aplicação da justiça humana exibe já uma orientação e prescrição colocada pelo capítulo, quiçá não pelo conjunto dos Ensaios, que atenta para as lições do que há de imperfeito e mal realizado no mundo, nas condutas e nas relações estabelecidas entre os homens, exortando a uma correção sem padrão de medida, se não negativo e de que se deve afastar. Ao invés de tomar um modelo idealizado de perfeição a ser imitado, presente neste ou em outro mundo, toma um, incorreto e defeituoso, a ser evitado.

${ }^{15}$ Colhida no curso deste movimento introdutório, em que se acumulam contra-exemplos instrutivos de toda ordem, o texto parece apontar para o tema da "maneira" que constitui o cerne do que é tratado no capítulo.

${ }^{16}$ A inscrição de uma tal disciplina par contrariété na tradição da sátira, não fosse evidente, ainda nos é expressamente lembrada pela citação de uma, de Horácio, logo no início. Num mesmo movimento vemos Montaigne preceituar a boa "maneira" de conversar, em que a
} 
oposição entre os "esprits". Aquela impõe, em nome da razão e da verdade, contra a dissimulação e adulação, um caráter belicoso à conversa, no plano das matérias examinadas; esta, demanda uma conduta regrada, prudente e capaz do interlocutor, no plano da maneira.

\subsection{A "economia" da relação}

No primeiro passo e desenvolvimento em que aflora no texto o tema da conference, Montaigne estabelece, por assim dizer, uma concepção geral dela e esboça as suas primeiras "conveniências". È nos seguintes termos que entra em seu assunto:

"[B] Le plus fructueux et naturel exercice de nostre esprit, c'est à mon gré la conference. J'en trouve l'usage plus doux que d'aucune autre action de nostre vie; et c'est la raison pourquoy, si j'estois asture forcé de choisir, je consentirois plustost, ce crois-je, de perdre la veue que l'ouir ou le parler. Les Atheniens, et encore les Romains, conservoient en grand honneur cet exercice en leurs Academies. De nostre temps, les Italiens en retiennent quelques vestiges, à leur grand profict, comme il se voit par la comparaison de nos entendemens aux leurs. L'estude des livres, c'est un mouvement languissant et foible qui n'eschauffe poinct: là où la conference apprend et exerce en un coup." (III VIII, p. 922-3)

De modo breve e elogioso ${ }^{17}$, ele a situa e destaca entre as "action[s] de nostre vie", como frutuoso e natural "exercice de nostre esprit", disciplina prazerosa ("plus doux [...] action") que aproveita ("à leur grand profict") aos "entendemens" e que é oposta e confrontada a um outro exercício do espírito, "I'estude des livres", sendo, sobretudo, preferida por conjugar, diferentemente deste, instrução e exercício. È, precisamente, este confronto inicial com a "leitura" que melhor nos instrui sobre o valor que lhe é atribuído. Com efeito, enquanto a "leitura dos livros", como julga o Ensaísta, é um "movimento

\footnotetext{
"contradição" por repreensão, sem cólera, é peça chave, e "enforcar-se" ao exibir sua impaciência ao discutir com o "tolo".

${ }^{17}$ A expressão superlativa deste gosto leva Montaigne a enaltecer a conversa tanto por afirmar que, caso fosse forçado a escolher, preferiria perder a visão a perder a audição e a fala (cf. id. ibid.: "[...] et c'est raison pourquoy, si j'estois asture [ = a cette heure] forcé de choisir, je consentirois plustost, ce crois-je, de perdre la veuë que l'ouir ou le parler"), quanto por referir o prestígio que gozara entre os antigos, atenienses e romanos, e coevos, italianos, que do seu exercício obtêm a superioridade de "entendimento", demonstrada pela comparação com o dos franceses (cf. id. ibid.).
} 
lânguido e fraco", que carece da conjunção de "ensino e exercício" - ela "instrui" o leitor mais enchendo sua cabeça com um saber alheio e pronto, que ele não digere e transforma em $\mathrm{seu}^{18}$, do que formando pela verdadeira compreensão, transmudada em experiência e capacidade de juízo -, a conference, por seu lado, reúne num só movimento ("en un coup") as lições das "contradições dos julgamentos", como ainda veremos, e o exercício efetivo do entendimento e do juízo que, ao responder, mobiliza suas razões no calor da hora, sob a pressão dos "golpes" e objeções do oponente, tal como se evidencia pela imagem da "justa dialética" que nos é oferecida logo a seguir:

"Si je confere avec une ame forte et un roide jousteur, il me presse les flancs, me pique à gauche et à dextre, ses imaginations eslancent les miennes. La jalousie, la gloire, la contention me poussent et rehaussent au dessus de moy-mesmes. Et l'unisson est qualité du tout ennuyeuse en la conference." (id. ibid., p. 923)

Aqui, como se pode ver, Montaigne insiste na idéia de uma "oposição" por "pressão" ("presse") e "golpe" ("pique") do adversário, que opera, pelo embate, um movimento das "imaginations". Diante das "imaginations" contrárias - leiam-se objeções, contra-argumentações - deste "roide jousteur", Montaigne vê as suas serem lançadas adiante ou para fora ("eslancent"), num movimento que, embora possa acatar os reparos que lhe são feitos, parece mais rejeitá-los em "defesa" de sua posição ${ }^{19}$, já que seus "impulsos", indicados aqui pelos termos "rivalidade" ("jalousie"), "ambição" ("gloire", que é, mais propriamente aqui, desejo de glória), e "espírito de luta" ou "contenda" ("contention"), são os de resistir aos golpes e até superá-los. Contudo, note-se, por ora, que eles somente o impulsionam ("poussent") e alçam ("rehaussent") acima de si mesmo, e não acima do adversário, como se

\footnotetext{
18 Uma das linhas de força do capítulo, se não dos Ensaios, faz exatamente a crítica desta relação exterior com a ciência, que exige apenas a memorização e repetição, tal e qual, das lições de "autoridade". Não devemos, no entanto, acreditar numa desqualificação dos livros, sobretudo se nos lembrarmos que este mesmo capítulo se encerra com uma leitura das Histórias de Tácito. (Sobre esta relação com os saberes cf. I XXV, Du pedantisme e I XXVI De l'institution des enfans, passim.)

${ }^{19}$ O sentido exato desta "defesa" e "rivalidade" ficará claro só mais tarde. Adiantemos somente que Montaigne descreverá duas vitórias: uma do assunto ("subject"), para a qual diz ser "quase indiferente", outra da conduta e ordem, que parece valorizar. Veremos as razões desta posição, mas é de notar que nada nesta descrição aponta uma "vontade" de superar a posição do adversário na "matéria". A resistência é simplesmente a que as boas regras da conversa determinam. Pertence, portanto, ao "plano da manière".
} 
poderia esperar de quem defendesse de modo excessivo a "verdade" de uma tese.

O reparo final sobre o "uníssono" que provoca "tédio" na conversa merece um comentário, pois soma um elemento fundamental ao nosso quadro geral das qualidades da conference. O mais importante para a sua concepção que desponta aqui é que ao "uníssono", ou seja, esta qualidade das vozes concordantes e que soam conjuntamente em harmonia na conversa, adere e dele não se separa o "tédio", contrariamente a toda vivacidade e movimento da conversa discordante. Aqui, nos lembramos da oposição com o frio movimento da leitura (Cf. id. ibid., p. 923: "un mouvement languissant et foible qui n'eschauffe poinct") e o tédio que ele igualmente sugere. Ao contrário, a conversa deve acolher a discordância e a contradição, sob o risco de, não o fazendo, transformar-se em "adulação" e paralisar o pensamento, pois, este nasce precisamente das contradições que "obrigam" ao movimento e tornamno "necessário".

A preferência pela conference expressa por Montaigne, contudo, não é incondicional, mas assenta numa distinção da qualidade dos "esprits" com quem se relaciona:

"Comme nostre esprit se fortifie par la communication des esprits vigoureux et reiglez, il ne se peut dire combien il perd et s'abastardit par le continuel commerce et frequentation que nous avons avec les esprits bas et maladifs. II n'est contagion qui s'espande comme celle-là. Je sçay par assez d'experience combien en vaut l'aune." (id. ibid.)

Montaigne faz, neste passo, com claro tom de irritação, uma espécie de "balanço", contabilizado pela própria experiência ("je sçay par assez d'experience"), acima de tudo da perda no "contínuo comércio e freqüentação" com os "esprits bas et maladifs", mas também do ganho na "comunicação" com os "esprits vigoureux et reiglez"; o ganho, em um encontro, é tanto maior quanto a perda o é, no outro. Assim, elege um modelo de interlocutor, já referido anteriormente como "roide jousteur", com o qual o espírito se fortalece e ganha vigor, na medida em que, frente a sua conduta vigorosa e regrada, ele se vê coagido ao exercício de pensamento. Diante deste espírito, que é "capaz" 
de interrogá-lo, de pressioná-lo e de contrariá-lo, o seu próprio espírito se exercita e cobra forças, na medida mesma em que o outro se põe contra ele, contra a opinião dele, e o força a responder por ela e sustentá-la por razões. Mas, atentemos para o fato de que ele não é portador apenas de vigor, mas é também aquele que combate com regra. Logo, sua distinção derivará, em última análise, da obediência àquilo que prescreve a manière, a boa condução da conversa, que ao longo da exposição se definirá. Ao contrário, os outros, "baixos e doentios", são fator de "contágio", espalham sua própria doença, levando o espírito a perder e se abastardar. O seu caráter mais geral será recolhido pelos traços que compõem a figura do "tolo" ("sot"), que o capítulo longamente critica, dada a sua inadequação às boas regras de condução da conversa.

Não se pode deixar de notar, ao lado desta alteração de humor ${ }^{20}$, que emerge ao falar dos espíritos baixos, o caráter altamente seletivo ${ }^{21}$ da conversa: "J'ayme à contester et à discourir, mais c'est avec peu d'hommes et pour moy" (id. ibid., grifo meu). Poucos parecem "aptos", porque "vigorosos e regrados", aos olhos de nosso autor. Em outras palavras, o seu exercício se restringe aqui a um círculo muito pequeno de homens, dotados de uma rara habilidade e "competência". Some-se a este traço "aristocrático", uma última "conveniência", que determina que um "homme d'honneur" "conteste e discorra" não para deleite da audiência, dando-se em espetáculo, mas em proveito próprio: "Car de servir de spectacle aux grands et faire à l'envy parade de son esprit et de son caquet, je trouve que c'est un mestier tres-messeant, à un homme d'honneur." (id. ibid.) Observemos, somente, que se entrevê já por esta exclusão certo caráter de relação privada $^{22}$, e de amizade, assinalado à

\footnotetext{
${ }^{20}$ Montaigne semeia em vários pontos deste capítulo a expressão desta irritação com os "esprits bas et maladifs". Mas, como nos avisou desde o começo, e relembra ao longo da exposição, não corrige os seus vícios, que são "quase naturais e incorrigíveis", apenas os expõe no intuito de que outros se corrijam.

${ }^{21}$ Sobre esta distinção e a expressão do gosto seletivo de Montaigne nas conversações V. III III, Des trois commerces, p. 824: "Les hommes de la societé et familiarité desquels je suis en queste, sont ceux qu'on appelle honnestes et habiles hommes: l'image de ceux cy me degouste des autres".

${ }_{22}$ Marca igualmente este traço de familiaridade e amizade, ao assinalar a finalidade desta freqüentação, em III III, p. 824: "La fin de ce commerce, c'est simplement la privauté, frequentation et conference: l'exercice des ames, sans autre fruit. En nos propos, tous subjects me sont égaux; il ne me chaut qu'il n'y ait ny poix ny profondeur: la grace et la pertinence y sont tousjours; tout y est teinct d'un jugement meur et constant, et meslé de bonté, de franchise, de
} 
conference montaigneana, que desgosta das "ordonnances penibles de [la] courtoisie" - "servil e importuna usança", que impõe um regime mais cerimonioso e cauteloso às conversas ${ }^{23}$.

Mas, a maior parte das "conversações" se dá, pode-se presumir então, com aqueles que não cumprem os difíceis requisitos impostos pela conversa ideal que aqui já começa a se projetar. São todos aqueles afetados pela "má qualidade" representada, em geral, pela "tolice" ("sottise"), da qual se verão no texto muitas espécies. E é exatamente no confronto com esta "mauvaise qualité", que o ensaísta acaba ele mesmo por se desviar tão importunamente dos rumos da boa conference, como exibe ao declarar sua intenção de auto-acusação:

"La sottise est une mauvaise qualité; mais de ne la pouvoir supporter, et s'en despiter et ronger, comme il m'advient, c'est une autre sorte de maladie qui ne doit guere à la sottise en importunité; et est ce qu'à present je veux accuser du mien." (id. ibid.)

É, pois, nesta tensão dos dois encontros, com a "aptidão" e a "inaptidão", que se desenvolverá todo primeiro movimento do texto, até o ponto em que Montaigne acusará em si mesmo o vício que anuncia neste começo.

$\mathrm{Na}$ continuação de sua discussão e antes ainda de tocar mais diretamente no problema da manière, Montaigne se ocupa das condições gerais para o estabelecimento da conference e cuida de expor mais precisamente o que concebe como seu "ideal". De maneira mais geral, nos deparamos aí com a exposição da "sociedade e familiaridade" de que diz gostar e com uma "descrição" e "prescrição" da atitude esperada, porque apta, dos interlocutores frente uns aos outros, o que, em última instância, depende da atitude frente às suas próprias opiniões sobre as matérias disputadas e frente às opiniões que Ihe são contrárias. Disso deriva a capacidade para falar

gayeté et d'amitié. Ce n'est pas au subject des substitutions seulement que nostre esprit montre sa beauté et sa force, et aux affaires des Roys; il la montre autant aux confabulations privées".

${ }^{23}$ Cf. id. ibid. 
("discorrer e contestar"), segundo convém, e para ouvir, igualmente. Para tanto ele põe, de início e num só movimento, 1) a necessidade de contradição, no que concerne às opiniões que se devem exprimir sobre as matérias; 2) a universalidade de sua "competência", quanto às mesmas matérias; e 3) a quase indiferença em obter a vitória na disputa, no que tange ao assunto (Cf. id. ibid., p. 925: "Il me chaut peu de la matiere, et me sont les opinions unes, et la victoire du subject à peu près indifferente"). Vejamos como se constrói no fio do texto cada ponto.

Montaigne inicia o aprofundamento da discussão nos indicando a "postura" própria que assume diante da diversidade das opiniões:

"J'entre en conference et en dispute avec grande liberté et facilité, $d^{\prime}$ autant que l'opinion trouve en moy le terrein mal propre à y penetrer et y pousser de hautes raçines. Nulles propositions m'estonnent, nulle creance me blesse, quelque contrarieté qu'elle aye à la mienne. II n'est si frivole et si extravagante fantasie qui ne me semble bien sortable à la production de l'esprit humain. Nous autres, qui privons nostre jugement du droict de faire des arrests, regardons mollement les opinions diverses; et, si nous n'y prestons le jugement, nous y prestons aiséement l'oreille." (id. ibid., p. 923).

Este texto toca nas razões mais profundas da "disponibilidade e capacidade" de Montaigne para a conference e a disputa. Aqui temos traços que o autor entra a descrever como dele próprio e que são determinantes da condução frutuosa e agradável da conversa. Sendo ela a ocasião de se deparar com opiniões e crenças diversas e contrárias à sua, é do fato de não se prender fortemente a nenhuma que ele deriva sua "aptidão". A grande dificuldade que esta postura tenta contornar é a da "paixão" suscitada pelas opiniões contrárias, precisamente porque parece haver nos homens uma disposição a se apegar de tal modo às suas que não suportam vê-las contrariadas. Embora o desprendimento e a ausência de paixão sejam condições sine quibus non da boa conduta, não serão suficientes, como veremos. Esta postura tranqüila diante da contradição sendo fruto, adiantemos, de uma relação correta com as matérias do dizer, deverá compor ainda com uma correta relação com as "diversas formas" dos espíritos, as diversas "maneiras do dizer" para que o domínio e mestria de conduta sejam completos, 
no que Montaigne acusa ser mal-sucedido, pois irrita-se ao encontrar-se com o "tolo". Mas, voltemos ao comentário do trecho citado.

Nele se afirma, antes de tudo, uma "grande liberdade e facilidade" para conversar e disputar, fundadas numa característica dele próprio, Montaigne, que alega ser um "terreno impróprio" para a fixação ("penetrer et pousser de hautes racines") desta "planta" que é a opinião. Ora, o que esta imagem quer nos sugerir? Dada uma matéria qualquer, nosso autor deixa claro que sua opinião acerca dela jamais é tão firme a ponto de se lhe prender e aderir, de se fixar ao seu "espírito", e isto, conseqüentemente, o impedir de conversar e disputar. Supõe-se aqui, nitidamente, que "a liberdade e facilidade" de entrar em conversação estão ligadas diretamente a este desarraigamento, a este desprendimento das próprias opiniões sobre matérias quaisquer. A entrada é livre e fácil, quando as próprias opiniões sobre as matérias não obstam que se converse. Mas, elas se constituem em obstáculo e dificuldade, se, ao contrário, são transformadas em convicções fortes pelo arraigamento, caso em que à opinião se soma a crença em sua "correção" ou "verdade", como se traduzissem a realidade mesma da matéria sobre a qual se opina. Para que isto não ocorra é preciso não pensar, a priori, que se está com a razão no que se afirma sobre um assunto e não pressupor, de modo tácito, que se possui efetivamente algo mais do que uma mera dóxa, no que se exprime por uma proposição. O que de modo nenhum significa um estado ou disposição em que o espírito encontrar-se-ia completamente esvaziado de opinião própria acerca das matérias que se põe a disputar. Ele não vive em sentido estrito de um modo adoxástos, como propugnavam os pirrônicos, se com isto entendêssemos uma completa carência de opinião. Tem-se, antes, a afirmação de uma disponibilidade do espírito para o exercício do julgamento, ou seja, a capacidade de ponderar os prós e os contras e de desprender-se das opiniões que possui, toda vez que uma boa razão o fizer oportunamente abandoná-la. Para a economia da conference esta atitude é fundamental, pois traduzir-se-á em abertura para a investigação e o exame, capacidade de pôr à prova as próprias posições, de suportar a contradição e aceitar a refutação. Capacidade que se estende ainda igualmente ao exame das posições alheias, quando, na qualidade de objetor, também não as toma por verdades, não importando, 
como ainda veremos, quanta autoridade esteja assentada em, ou seja reclamada por, quem as profira.

A gênese deste "estado de alma" ou "disposição", desprendida da opinião, ele nos oferece, nas poucas linhas seguintes. Tal desprendimento se funda na renúncia do julgamento a dar sentenças ("nous qui privons nostre jugement du droict de faire des arrests"), ou seja, em assentir ou não assentir à verdade de uma proposição qualquer, que temos por nossa opinião, acerca de um assunto qualquer. Este estado de "suspensão" ou de "retenção" do assentimento é, por sua vez e a um só tempo, produzido e reforçado pela experiência do espetáculo da profusão, variedade e diversidade da "produção do espírito humano", que, segundo esta mesma experiência, é capaz de engendrar (o que não causa espanto aos olhos do ensaísta: ele observa "mollement les opinions diverses" que a ele "semblent bien sortable" a esta produção) as fantasias mais frívolas e mais extravagantes ${ }^{24}$. O que está em causa aqui é a capacidade do espírito humano em forjar, sobre a mesma matéria, opiniões e razões múltiplas e diversas - e, no limite, contraditórias -, e ainda o caminha epistemológico e moral que a experiência desta diaphonía propõe ao filósofo pirrônico ${ }^{25}$. Este trajeto é como pressuposto, quando Montaigne inclui-se entre aqueles que "privam seu julgamento do direito de dar arrestos"; e, bem entendido, se, por um lado, alimenta sua própria disposição a não julgar a partir deste espetáculo da contrariedade, por outro, ao achar-se neste estado de "privação", o espírito se encontra aberto à contemplação da multiplicidade das proposições e crenças, acolhidas, então, calmamente (mollement) e atentamente, já que em não lhes emprestando o julgamento,

\footnotetext{
${ }^{24}$ A propósito desta profusão de extravagâncias e a crença em sua verdade v. I XXI, De la force de l'imagination e I XXIII, De la coustume et de ne changer aisément une loy receüe.

${ }^{25}$ Sabemos que para o Pirronismo, a "suspensão de juízo" resulta, seja da capacidade de produzir discursos igualmente persuasivos que sustentem uma e outra parte da contradição, seja da mobilização das doutrinas contraditórias que já encontra disponíveis, elaboradas pelas escolas dogmáticas, conjugada à ausência de critério de verdade que permita operar a escolha entre um e outro destes discursos contraditórios. A dýnamis antithetiké produz os arrazoados de igual peso, ou alega o coro da diaphonía, a fim de estabelecer a isosthéneia, ou igual força dos argumentos pró e contra. Com isso, o cético acaba por se encontrar igualmente persuadido por um e outro lado e igualmente desprovido de critério que o habilite a escolher. Portanto, suspende ou retém seu assentimento sobre a verdade de um ou outro. Entra-se, por este procedimento, em epokhé, do que resulta para ele ainda, casualmente, um estado de tranqüilidade da alma (ataraxía). Tranqüilidade que, aliás, buscava quando se pôs a investigar, pois encontrava-se "perturbado" pela anomalia. (Cf. SEX. EMP. Hipotiposes Pirroneanas I, 1-12. Estes doze primeiros capítulos do primeiro livro como que estabelecem os conceitos mais fundamentais sobre que repousa o pensamento desta vertente das escolas céticas.)
} 
empresta-Ihes o espírito, contudo, facilmente a atenção (“'”si nous n’y [às opiniões diversas] prestons le jugement, nous y prestons aiséement l'oreille."), e aprecia sua capacidade persuasiva. Vejamos.

È difícil não ler nestas linhas uma alusão clara ao Pirronismo, o que não só a idéia de "privação do julgamento", que facilmente associamos à de epokhé, bem como a deste espetáculo da contrariedade, que ligamos à diaphonía sem grande esforço, como ainda a imagem da balança que segue imediatamente (Cf.III VIII, p. 923: "Où I'un plat est vuide du tout en la balance, je laisse vaciller l'autre, sous les songes d'une vieille") tendem a confirmar amplamente. No entanto, é preciso fixar nossa atenção, também, na idéia precisa de "exame" que a imagem mesma, e todo passo, sugerem. Montaigne diz, claramente, que deixa oscilar um dos pratos da balança "sob as divagações de uma velha". Mas isto, depois que a "privação do julgamento" esvaziou um dos pratos em decorrência da isosthéneia. Somente então ele deixa "o outro" oscilar sob o "peso" do que se considera, abre-se ao exame mesmo de "fantasias frívolas e extravagantes", e se permite, sem "perturbação", ponderar e pesar, não obstante sua frivolidade e extravagância, "loucuras" ("ravasseries") em crédito em torno de nós, tais como as que segue arrolando:

\footnotetext{
"Et me semble estre excusable si j'accepte plustost le nombre impair; le jeudy au pris du vendredy; si je m'aime mieux douziesme ou quatorziesme que treziesme à table; si je vois plus volontiers un liévre costoyant que traversant mon chemin quand je voyage, et donne plustost le pied gauche que le droict à chausser." (id. ibid.)
}

E insiste na idéia de que se deve ao menos "escutá-las". Simplesmente porque elas, ainda que pouco ou quase nada, pesam algo: "Toutes telles ravasseries, qui sont en credit autour de nous, meritent au-moins qu'on les escoute. Pour moy, elles emportent seulement l'inanité, mais elles l'emportent. Encores sont en poids les opinions vulgaires et casuelles autre chose que rien en nature" (id. ibid.). O peso que surge aqui associado "às opiniões vulgares e casuais", contudo, não deve nos levar a pensar em uma aproximação com o Ceticismo da Nova Academia, e sua afirmação de diferente "peso" persuasivo das 
proposições que faz pender um dos pratos da balança e opera como critério de escolha no domínio das ações e na "prática". Sabe-se como Montaigne, na Apologia, descarta qualquer verossimilhança ou "probabilidade" - a "inclination de jugement" que os Acadêmicos acolhiam, como diz nosso autor no passo que ora rememoramos ${ }^{26}$ - que se insinue no plano das opiniões que se exprimem sobre as matérias, e considera o "advis des Pyrrhoniens" mais "ousado" e mais "verossímil" (sic). O que as linhas que comentamos sugerem, no entanto, é que, o Pirronismo, tendo igualado todas as "representações" apenas do ponto de vista de sua verdade, e, por conseguinte, não havendo garantias de que correspondam a algo efetivamente real - e desta perspectiva equivalem-se tanto as "ravasseries" quanto as mais sofisticadas e sustentadas proposições da filosofia dogmática - deixa o espírito livre para a escuta e consideração de qualquer coisa e sua pesagem.

Por ora, então, apenas se confirma, em boa medida, que estamos diante, sobretudo, de uma abertura para o exame das opiniões a serem confrontadas, por mais "vulgares e casuais" que se apresentem. E que se trata ainda de postular para esse exame a tranqüilidade moderada de quem aceita pôr à prova, com os riscos que isto comporta, as próprias opiniões. Do contrário, ou seja, de apegar-se imoderadamente a elas, corre-se o risco de incorrer no vício oposto ao que se quer evitar; ou seja, de fugir da superstição, acaba-se por aproximar-se demasiadamente da "obstinação" (opiniastreté), que se origina do apego às próprias opiniões e razões: "Et, qui ne s'y laisse aller jusques là, tombe à l'avanture au vice de l'opiniastreté pour eviter celuy de la superstition" (id. ibid.). Logo, o que ele de certa forma põe como exigência, apoiada na retenção do julgamento, é que se evite a "precipitação" em julgar que se está com a razão, enquanto o outro, em sua posição diversa ou contrária, estaria errado. Em outras palavras, a postura e atitude "dogmática" e irritada do opiniastre. Temos, em suma, como resultado, um estado ou disposição de espírito atento às opiniões contrárias, sem que, no confronto com elas, este mesmo espírito experimente qualquer perturbação.

Assim, o Ensaísta - operando evidentemente com todo um aparato e instrumental conceitual tomado de empréstimo à escola pirrônica, que se define

${ }^{26}$ Cf. Essais, II XII, Apologie de Raymond Sebond, p. 561 ss. 
exatamente pela permanência na zétesis, ou seja, em dúvida e em constante exame e investigação -, num mesmo gesto, gesto de um parágrafo, nos devolve ao "solo" sob o qual se erige todo o desenvolvimento da sua concepção de conference - já que assim inscreve o homem definitivamente numa "escole d'inquisition" ${ }^{27}$, e assinala para ele uma outra tarefa: a de bem conduzir a busca, ainda que falhe na captura da presa, deixando-o incumbido apenas do que diz respeito à manière -, bem como define e marca a sua primeira exigência - porquanto no passo que nos ocupa, o que esta "postura", sem dúvida instruída e alimentada pelo Ceticismo, permite, antes de tudo, é combater o vício da opiniastreté que impede a conversação, ao recusar o confronto de opiniões. E o combate precisamente porque, se não atribui verdade às opiniões diversas, confere-lhes, ao menos, não igual, mas diferente peso ao abrir-se para a sua escuta. Peso que tem, ao que parece, função ao menos de instilar alguma dúvida e hesitação no bloco compacto e seguro das convicções dos "obstinados", e relativizá-las. Assumindo-se ou não a inscrição de Montaigne na escola de Pirro $^{28}$, o que, em suma, esta "disposição" descrita põe como condição primeira para o estabelecimento da conference, dentro do clima de anti-dogmatismo que o texto respira, é a capacidade de ouvir e aceitar opiniões divergentes e, no limite, contraditórias às nossas, sem ser afetado por isso, já que a não afecção surgiu, propriamente, como condição para que se proceda racionalmente ao exame. Por banal que pareça, não é outra coisa que

\footnotetext{
${ }^{27}$ Cf. id. ibid., p. 928.

${ }^{28} \mathrm{O}$ que dependeria de um exame detido da Apologia e que foge ao escopo deste estudo. No entanto, podemos aduzir que é como se o Ceticismo fosse tomado, sim, como um pressuposto - fundamental, é evidente, pela mudança que ocasiona na relação com as opiniões e a tranqüilidade que se segue a sua suspensão -, mas, a abertura para a diversidade e contrariedade de opiniões que se insinua não coincide inteiramente com sua zétesis. Isto porque a conference tem assinalada a ela um exercício um pouco mais amplo do que simplesmente o da produção de antilogias por uma dýnamis antithetiké com vistas à reposição da "suspensão" e da ataraxia. Fazendo-a penetrar no terreno da moralidade, Montaigne assinalará para ela - além do agradável exercício do espírito entre amigos, em que demonstram a força e beleza de suas almas, sem outro fruto, anunciado desde o capítulo De trois commerces (Cf. supra n. 6) - também uma função de entre-correção moral. Além disso, a potência negativa e crítica das contradições será erigida em "órgão" do conhecimento de si, pois no robusto exercício do pensamento e do julgamento que a conference enseja, o sujeito tem a oportunidade não só de reconhecer seus erros de opinião, a fraqueza e fragilidade de seu conhecimento, em suma, sua ignorância e imbecillitas, como ainda seus erros de conduta, espelhados no olhar nada complacente do amigo. Mas tudo isso quando a conversa ocorre com os esprits vigoureux et reiglez, o que não é às mais das vezes o caso, como já entrevimos. No encontro com o tolo, a mesma capacidade é instrumentalizada para avaliar a estatura intelectual, a suffisance, do homem com quem se depara, e para reconhecer e estabelecer as verdadeiras superioridades, que se medirão pela manière.
} 
o texto afirma. Se dermos, agora, um passo, veremos que a contra-partida desta "disponibilidade para ouvir" é dada, simplesmente, pela "coragem em falar" ao outro, e em falar tudo o que se pensa, sem dissimular.

Montaigne extrai, antes de avançar na exposição, a conclusão latente no que havia dito (em resumo, diferentemente do opiniastre, não tendo opinião arraigada, as proposições não o espantam, as crenças não o ferem, ele aceita qualquer opinião para exame): "Les contradictions donc des jugemens ne m'offencent ny m'alterent; elles m'esveillent seulement et m'exercent" (id. ibid., p. 924). Assumindo e se reconhecendo nesta figura que não se ofende nem se altera, apenas desperta e se exercita com as "contradições dos julgamentos" - traço novo e sério de que se revestem agora as "opinions diverses" ${ }^{29}$-, ele já aponta o que se esperaria como postura dos interlocutores da conference: sua atitude calma frente às contradições depende e deriva da natureza da adesão que dá às suas opiniões e crenças, mantendo-se sempre disposto a reexaminá-las. È como se ele reservasse o espaço do exame, o lugar de "pôr à prova" corajosamente não só toda convicção, mas também toda conduta que se paute por uma convicção, por meio de certa "distância", que habilita tanto a ouvir as contradições, quanto a contradizer. Em toda seqüência imediata do texto, ele oscila e pulsa entre esta expectativa - e até mesmo afirma tentar alimentá-la como atitude - e o que efetivamente encontra em prática na freqüentação dos homens. Confrontam-se, assim, a expressão mais clara do ideal de "sociedade e familiaridade" que nos propõe e os dois desvios que se tem de evitar. Montaigne mobiliza o tópos da mediania para descrevêlos, uma vez que a escolha operada por ele exclui duas modalidades de conversa - assentadas precisamente nos "caracteres", "ações" e "paixões" dos interlocutores -, as quais são como que os extremos viciosos - um, associado à temeridade; o outro, à covardia - de que a conference descrita é o meio termo virtuoso. Poderíamos rotular o primeiro desvio de postura combativa ou

\footnotetext{
${ }^{29}$ De fato, Montaigne anteriormente falava em "fantasias frívolas e extravagantes" e mesmo "loucuras" e "superstições", aceitas para evitar a "obstinação". Agora parece se reorientar para um aspecto mais "sério" da conversação, em que as oposições assumem caráter de "correção" e não são nada frívolas.
} 
erística, sem que Montaigne a nomeie em nenhum momento expressamente assim; o outro, de dissimulação ${ }^{30}$, que nomeia com todas as letras.

Adiantando um pouco, notaremos que a primeira figura é conseqüência direta do caráter do opiniastre, a que já se aludiu. De fato, em sua "obstinação" e dogmatismo Montaigne parece ver implicada, por um lado, uma aspereza que recusa qualquer ponto de vista diverso e, que, portanto, luta por prevalecer sobre os alheios; e, por outro, uma irritação por não aceitar que não acatem as reprimendas e correções que formula. Nas duas situações a "cólera" se manifesta como a expressão passional do excesso e imoderação em que incorrem os "obstinados". Já a outra figura, por falta de coragem, recusa terminantemente a contradição, mas de maneira diversa: sempre aprovando e dizendo sim, louvando e abrindo alas. No contraste com estas duas posturas, e situando-se a igual distância destes extremos, esboça-se uma "disciplina" que não dispensa a "querela rude" e a "repreensão", e ainda assim permite aos interlocutores manter o perfeito domínio racional sobre si, excluindo toda "cólera". Vejamos em que condições, uma vez ainda, no fio da prosa do ensaísta.

Com efeito, mudando da perspectiva do que se deveria fazer para o que se faz realmente, nosso autor começa a se queixar da atitude dos homens ${ }^{31}$ do seu tempo: "Nous fuyons à la correction; il s'y faudroit presenter et produire, notamment quand elle vient par forme de conference, non de rejance" (id. ibid.). Esta mudança e queixa nos traz pelo menos dois elementos para a economia da relação que estamos descrevendo. Além de uma distinção entre duas formas de "correção", por conference e por rejance ${ }^{32}$, a insistência

\footnotetext{
${ }^{30}$ É fácil ver aqui que Montaigne atualiza de modo condensado a crítica que já Platão movia contra a "Sofística" em sua dupla face: dissimulação e erística. Ambas igualmente comprometidas com uma intenção que se desvia da verdade em prol de uma utilidade ou proveito. Não é outro o veredicto de Aristóteles, que se esforça para distinguir a filosofia da sofística, mostrando que ambas coincidem nos seus âmbitos, mas diferem na intenção.

${ }^{31}$ É difícil dizer com os elementos que o texto nos dá o quanto Montaigne se vê implicado nesta "fuga", já que o texto escorrega de um "je" a um "nous" que o inclui de maneira ambígua, e que não podemos afirmar que seja simplesmente algo que encontre fora, somente na atitude dos outros homens.

${ }^{32}$ Ao que parece, não se trata de uma recusa dos homens do tempo em corrigir-se tout court. A "rejance", apenas mencionada, compete com a correção pela conversa, sendo outra ocasião que os homens têm para cumprir este "ofício" de humildade. Podemos reconhecer nela o púlpito em que se expõe a norma: do mestre, na aula, do padre, na prédica. Podemos vê-la como centro irradiador de um discurso em que se deposita uma verdade pronta, acabada, que deve ser respeitado e venerado, porque ditado, seja pela autoridade ou antiguidade, seja pela própria divindade. Diferentemente, porém, da conversa, nela os homens corrigem suas
} 
forte na necessidade de se expor ("presenter et produire") à "correção" da conversa associa-se claramente à idéia das "contradições dos julgamentos" ou seja, o confronto das "opiniões" e "juízos" contraditórios parece propiciar, no mínimo, a mudança ou abandono de uma opinião errônea e, no limite, até mesmo a correção de uma conduta.

No entanto, a resposta que comumente se dá a contradição corretora - que se ouve - é não uma acolhida calma para inspecionar-lhe a "justeza e justiça", mas simplesmente a recusa agressiva acompanhada de uma defesa a qualquer custo: "A chaque opposition on ne regarde pas si elle est juste, mais, à tort ou à droit, comment on s'en deffera. Au lieu d'y tendre les bras, nous y tendons les griffes" (id. ibid.). Desinteressada da justiça das oposições que se apresentam, esta atitude empenha-se apenas em desfazer-se delas, em manter sua posição, valendo-se, como parece sugerir o texto, de quaisquer expedientes ("à tort ou à droit"). A negação da tese do oponente é radical e valem quaisquer meios para combatê-la. Transforma-se a própria opinião em verdade pessoal e causa que deve triunfar a qualquer custo. Ou seja, antepõese uma causa e um interesse pessoal que uma opinião exprime, e a vitória desta posição, a uma possível correção, que teria como "horizonte" algo maior e melhor do que esta "verdade" parcial possa representar.

Montaigne, ao contrário, afirma que suportaria "estre rudement heurté par [s]es amis: Tu es un sot, tu resves" (id. ibid.). Obviamente, o acento na capacidade de sofrer ("je souffrirois", ele diz) a rudeza da exortação do amigo tem por esteio principal a posição anti-dogmática e a "distância" já indicadas, que trazem em seu bojo a incerteza e o reconhecimento de que se pode estar em erro, a dizer tolice ou sonhar - e, por isso mesmo, serve de remédio à "obstinação". Serão explicitadas em breve as razões desta capacidade em sofrer, aliada sempre da capacidade de contradizer. Mas, antes nos é apresentado o ponto alto desta atitude, verdadeiro emblema da conference montaigneana, que se encontra na expressão da exigência de "querela e repreensão" para esta "sociedade e familiaridade" de que diz gostar e que confirma pela autoridade do parecer de Cícero sobre as disputationes:

imperfeições sem se expor, apenas realizando uma inspeção de suas próprias consciências e medindo silenciosamente o quanto seus pensamentos e atos se têm afastado do modelo de correção assumido pelo discurso que os repreende. 
"J'ayme, entre les galans hommes, qu'on s'exprime courageusement, que les mots aillent où va la pensée. II nous faut fortifier l'ouie et la durcir contre cette tandreur du son ceremonieux des parolles. J'ayme une societé et familiarité forte et virile, une amitié qui se flatte en l'aspreté et vigueur de son commerce, comme l'amour, és morsures et esgratigneures sanglantes.

[C] Elle n'est pas assez vigoureuse et genereuse, si elle n'est querelleuse, si elle est civilisée et artiste, si elle craint le hurt et a ses allures contreintes.

Neque enim disputari sine reprehensione potest." (id. ibid.)

Notemos, no entanto, que já aparece no texto citado acima, uma outra oposição, agora voltada contra a "postura dissimulada", a que, aliás, Montaigne já aludiu, en passant, quando excluiu, como tedioso ${ }^{33}$, o "uníssono" do regime da conversa, e que há pouco aproximamos da idéia de harmonia e de falas concordantes. Vale adiantar que o ensaísta concluirá a passagem de que nos ocupamos, reafirmando que "c'est un plaisir fade et nuisible d'avoir affaire à gens qui nous admirent et facent place", e marcando com vigor sua preferência, ainda uma vez, ao dizer que "cherche à la verité plus la frequentation de ceux qui [lui] gourment que de ceux qui [lui] craignent", conformando-se ao que ordenava Antístenes: "Antisthenes commanda à ses enfans de ne sçavoir jamais gré ny grace à homme qui les louat". Mas, sigamos.

Montaigne postula, então, que se fortifique e endureça o ouvido contra a "adulação", isto é, contra a "suavidade do som cerimonioso das palavras" ("tandreur du son ceremonieux des parolles"), em proveito de uma "societé et familiarité forte et virile", e de uma "amitié" que se compraz e adula ("flatte") na aspereza e vigor de seu comércio. Algo próximo da imagem da "justa" encontrada no início, acrescida agora da qualidade de "amizade" que se dá a esta relação. Que se repare como desloca com não pouca graça os termos que referem seu problema: o que adula é a aspereza, vigor, força e virilidade da repreensão do amigo na disputa, não a "ternura" e suavidade das

\footnotetext{
${ }^{33} \mathrm{O}$ "tédio", para fixar um pouco mais as posições inversas e simétricas de que a conference deve se afastar, é exatamente a "afecção" que suscita quem erra por falar o mesmo, não contrariar, não corrigir o interlocutor, perdendo com isso a conversa em sua utilidade. Ao passo que, a "cólera" é exatamente, como até aqui foi descrito, o erro de quem ouve o contrário do que pensa e não suporta a correção; erro do "obstinado", portanto.
} 
palavras de cerimônia, não a "civilidade e o artifício", que impedem que a relação assuma bastante "vigor e generosidade", pois "temem o choque e têm os passos constrangidos". Melhor dizendo, na conversa não se pode evitar a "correção" mútua, que se dá por meio das "contradições dos julgamentos". Em sua coragem, que representa a generosidade e vigor máximos da amizade, a fala do amigo deve excluir a civilidade e o artifício da conversa, pois não se deve temer o choque, nem constranger os passos, nem ainda ocultar nada, deixando as palavras exibirem tudo o que se pensa. Ela deve revestir, portanto, esta forma querelleuse, como nos diz o ensaísta, que é a condição magna de seu proveito e prazer.

O que se recusa, em suma, é uma civilidade que teme o confronto vigoroso das "opiniões", as generosas "contradições dos julgamentos", e que, por conseguinte, oculta o que verdadeiramente se pensa. E Montaigne, lamentando-se da dificuldade em "favorecer e alimentar" a liberdade de o advertirem pela facilidade que demonstra em ceder às correções, aponta claramente a falta de coragem em sofrer a correção como causa da postura dissimulada:

"[C] [...] Toutefois il est certes malaisé d'y attirer les hommes de mon temps: ils n'ont pas le courage de corriger, par ce qu'ils n'ont pas le courage de souffrir à l'estre, et parlent tousjours avec dissimulation en presence les uns des autres." (id. ibid.)

O que se pede, ao contrário, vem associado exatamente à "coragem" da fala em que "as palavras vão aonde vai o pensamento". Nada mais do que a exigência de "veracidade" na repreensão corajosa e generosa do amigo, que diz o que pensa ao amigo e o corrige, sem dissimular, uma veracidade temperada de "amabilidade" que Montaigne aproxima da relação amorosa além da amizade.

Quanto a esta exigência de "veracidade", é preciso atentarmos para o fato de que de modo nenhum se afirma com ela uma relação segura e certa do pensamento com as coisas em si mesmas, e, sim, a estreita e fiel correspondência de pensamento e palavras, do lógos e da léxis que lhe dá expressão. Isso fica claro se lembramos que, com a suspensão, houve o 
deslocamento de um plano que visa à relação entre o pensamento e as coisas, para outro, da relação entre as palavras e as "coisas", entendidas agora como os conteúdos destas "imaginações", sem que se disponha mais de critério para estabelecer sua verdade ou falsidade, já não mais em questão.

Desde o início, com efeito, deparamos com palavras como "imagination" e "fantasie", assaz freqüentes no jargão de nosso autor e que encontram sua origem, se não na própria escola cética, com certeza nas doutrinas acerca do conhecimento de sua principal rival: o estoicismo. Não é difícil demonstrar que os termos apontados remetem ao conceito estóico de phantasía, que é "comumente" vertido por "representação" na literatura especializada. O ceticismo ao suspender e reter o assentimento em nada afeta o conteúdo destas "imaginações”, como Montaigne mesmo nos instrui num passo da Apologia em que faz uma primeira exposição do ceticismo:

"[B] [...] Des trois actions de l'ame, l'imaginative, l'appetitive et la consentante, ils en reçoivent les deux premieres; la dernière, ils la soustiennent et la maintiennent ambigue, sans inclination ny approbation d'une part ou d'autre, tant soit-elle legere.

[C] Zenon peignoit de geste son imagination sur cette partition des facultez de l'ame: la main espandue et ouverte, c'estoit apparence; la main à demy serrée et les doigts un peu croches, consentement; le poing fermé, comprehantion; quand, de la main gauche, il venoit encore à clorre ce poing plus estroit, science.

[B] Or cette assiette de leur jugement, droicte et inflexible, recevant tous objects sans application et consentement, les achemine à leur Ataraxie, qui est une condition de vie paisible, rassise, exempte des agitations que nous recevons par l'impression de l'opinion et science que nous pensons avoir des choses." (II XII, Apologie de Raymond Sebond, p. 502-3)

Que a crítica cética se alimenta do próprio aparato conceitual estóico fica claro pelo modo como se imbricam aqui as referências às duas escolas. Mas o que nos interessa no momento é apenas destacar que das três ações, a "imaginativa", a "apetitiva" e a "judicativa", somente a terceira é "suspensa e mantida ambígua, sem inclinação nem aprovação", "reta e inflexível", enquanto as outras duas são "admitidas", "recebendo todos os objetos", porém, "sem aplicação e consentimento", isto é, sem julgar. As "imaginações" e os "apetites", portanto, continuam, assim, operando normalmente. Agora, se 
lembrarmos que estas imaginações referem-se, em grande medida, ao mesmo "pensamento" que Montaigne não quer ver encoberto por palavras na postura dissimulada, qualquer dificuldade que podíamos ter sobre a "veracidade" exigida para a busca comum empreendida pelos interlocutores da conference se dissipa.

Tampouco é difícil entender por que a repreensão veraz que se exigia do amigo deve ser, ao mesmo tempo, corajosa e generosa. Corajosa porque em sua franqueza arrisca a própria amizade. E generosa exatamente porque veraz, ou seja, porque nada oculta do que vê e pensa. Obviamente, esta coragem em corrigir que se demanda vem secundada pela coragem em sofrê-la, que Montaigne já apontava ao dizer que suportaria ser rudemente exortado pelos amigos, e que num segundo momento vemos aliada ao prazer de ser julgado e conhecido pelo outro:

"[C] [...] Je prens si grand plaisir d'estre jugé et cogneu, qu'il m'est comme indifferent en quelle des deux formes je le soys. Mon imagination se contredit elle mesme si souvent et condamne, que ce m'est tout un qu'un autre le face: veu principalement que je ne donne à sa reprehension que l'authorité que je veux." (id. ibid., p. 924-5)

Não importa em qual das duas formas ele o seja, isto é, se acusado ou desculpado, se vituperado ou louvado, se condenado ou absolvido, Montaigne afirma a superioridade de uma relação em que se expõe franca e abertamente ao olhar do outro, e a indiferença de que seja este outro que o contradiga e condene, quando em sua própria imaginação ele frequentemente se contradiz e condena. Apesar disso, reserva ainda para si, autonomamente, a liberdade de conferir "autoridade" às repreensões que Ihes são feitas. Tais oposições, em princípio, não gozam de autoridade sobre ele, pois não podem pretender-se legítimas em substituição a quaisquer outras. Ele as aceita desde que as tenha passado por seu próprio crivo e julgado que assim deve fazer, atribuindo a elas não certeza absoluta, mas apenas a certeza relativa que julga ela ter obtido no confronto situado das opiniões na ocasião. Faz até mais: para alimentar em outros a liberdade de corrigi-lo, corrige-se mesmo quando nisto reconhece haver perdas: "[...] je preste l'espaule aux reprehensions que I'on 
faict en mes escrits; et les ay souvent changez plus par raison de civilité, que par raison d'amendement: aymant à gratifier et nourrir la liberté de m'advertir par la facilité de ceder; ouy, à mes despans" (id. ibid., p. 924). Mas o que importa é que seja livre para aceitá-las ou não, sem que o outro reclame autoridade abusiva para as reprimendas que faz, pois, quando se trata não mais de ouvir uma repreensão, mas de fazê-la, ou seja, de falar, esta mesma postura "obstinada" erra ao assumir ares "demasiado imperiosos e magistrais" e, diante de uma recusa em aceitar a advertência, lamenta-se e toma por injúria tal recusa: "Mais je romps paille avec celuy qui se tient si haut à la main, comme j'en cognoy quelqu'un qui plaint son advertissement, s'il n'en est creu, et prend à injure si on estrive à le suivre" (id. ibid., p. 925). Vê-se como Montaigne descreve uma postura que não é a de mera aceitação da contradição corretora. Pois, se esta não desperta a "cólera", desperta a "atenção", e faz passar, diante da "contradição", ao exame conjunto que faz da verdade "causa comum". Logo, é preciso regular também a atitude daquele que repreende. Montaigne busca, sim, na conversa, a freqüentação dos que o maltratam com a razão, não com a "autoridade". No fundo, nenhuma das partes que entram em disputa pode assumir que seja, de algum modo, portadora e defensora da razão e da verdade. Estas não aderem, com certeza, a nenhuma das partes.

È isto que permite a Montaigne dizer: "Je festoye et caresse la verité en quelque main que je la trouve, et m'y rends alaigrement, et luy tends mes armes vaincues, de loing que je la vois approcher." (id. ibid. Que se note o quão ironicamente ele diz, arrematando a frase, que é de longe que ele vê se aproximar a verdade a que se rende. O que não significa que a "causa da verdade" possa ser simplesmente descartada, pois, é ao preservar, para a investigação e o exame conjuntamente empreendido, uma "causa comum" (com a qual ambos estão comprometidos, e pela qual estão previamente dispostos a abandonar suas "teses" parciais sobre as matérias tratadas) que a conference pode ter curso, proveito, fruto, como nos mostra o passo em que reafirma sua abertura "desperta" e "atenta" para a contradição, que aparece aqui como portadora de "instrução" voluntariamente buscada e acolhida: "Quand on me contrarie, on esveille mon attention, non pas ma cholere; je m’avance vers celuy qui me contredit, qui m’instruit. La cause de la verité 
devroit estre la cause commune à l'un et à l'autre" (III VIII, p. 924). Não sendo assim, arrisca-se o interlocutor a perder a razão e o juízo diante da contradição: "Que respondra-il? La passion du courroux lui a desjà frappé le jugement. Le trouble s'en est saisi avant la raison" (id. ibid.).

Montaigne avalia e responde ainda uma objeção que se poderia fazer a sua postura calma e corajosa tanto em corrigir como em ser corrigido. Trata-se da suposição de que se exigiria para esta atitude a força de um Sócrates que só acolhe abertamente as contradições aos seus discursos, porque dão a ele sempre nova oportunidade de triunfo e de vitória. Vale citar:

"[C] [...] Ce que Socrates recueilloit, tousjours riant, les contradictions qu'on faisoit à son discours, on pourroit dire que sa force en estoit cause, et que, l'avantage ayant à tomber certainement de son costé, il les acceptoit comme matiere de nouvelle gloire. Mais nous voyons au rebours qu'il n'est rien qui nous y rende le sentiment si delicat, que l'opinion de la préeminence et desdaing de l'adversaire; et que, par raison, c'est au foible plustost d'accepter de bon gré les oppositions qui le redressent et rabillent." (id. ibid., p. 925)

Como vemos, Montaigne rebate claramente esta suposição de que em sua força estaria a chave para a abertura para a conference. O que se percebe é que Montaigne não assume aqui a perspectiva dos fortes, ou sábios, como o Sócrates descrito, cuja força é sempre garantia de vitória sobre o adversário e motivo de nova glória. Ao contrário, o que se aponta é que, da perspectiva do "fraco", qualquer "opinião de preeminência e desdém pelo adversário", tornam o "sentimento assaz delicado" diante da contradição, o que impede exatamente de acolhê-las e corrigir-se por meio delas. Só aquele que se reconhece como "fraco" pode, desta posição humilde, aceitar a contradição corretora. É porque não possui o sentimento da preeminência nem desdenha o adversário que pode aceitar "as oposições que o retificam e recompõem".

Daí acaba por reafirmar o gosto pela freqüentação de quem maltrata e não de quem teme, tão conforme à ordem dada por Antístenes a seus filhos:

"[B] Je cerche à la verité plus la frequentation de ceux qui me gourment que de ceux qui me craignent. C'est un plaisir fade et nuisible d'avoir affaire à gens qui 
nous admirent et facent place. Antisthenes commanda à ses enfans de ne sçavoir jamais gré ny grace à homme qui les louat." (id. ibid.)

Reparemos, mais uma vez, como o "louvor", a "admiração", e a "concordância" daqueles que falam de modo a agradar, sempre dizendo sim, são excluídos das "conveniências" da conversa como prazer "insípido e prejudicial".

E o movimento mesmo se encerra, com uma consideração sobre a "vitória" que se poderia obter diante de um ou outro adversário:

"[B] [...] Je me sens bien plus fier de la victoire que je gaigne sur moy quand, en l'ardeur mesme du combat, je me faicts plier soubs la force de la raison de mon adversaire, que je ne me sens gré de la victoire que je gaigne sur luy par sa foiblesse." (id. ibid.)

Pesam-se duas possíveis vitórias: uma, no assunto, devida não a sua própria força, mas a fraqueza do adversário; outra, sobre si, devida a sua própria força em "dobrar-se sob a força da razão do adversário, no ardor do combate".

Se tivéssemos, por fim, de resumir o que ficou pelo caminho, diríamos que Montaigne, no De l'art de conferer, descarta do regime de sua conference, não só tudo que há de banal e corriqueiro nas conversações e relações comuns, como também, as duas contrafações que vimos situadas como extremos viciosos da conversa, para circunscrever seu exercício ao domínio de uma igualdade e amizade generosa e corajosa em suas correções, mantendo a "verdade" como "causa comum" e recusando toda "obstinação" dogmática que emperra o seu andamento, por não aceitar a contradição. Igualmente, excluem-se da relação as desigualdades hierárquicas e o prazer da assistência, em nome do proveito pessoal que esta "justa" rude pode trazer. Do amigo espera-se que ele repreenda e acuse tudo o que vê e pensa. No entanto, em sua áspera amabilidade não reclama para a advertência que dá mais autoridade do que ela comporta, reconhecendo sempre que poderia estar 
enganado em seu juízo e correção. Do amigo repreendido e exortado, por sua vez, espera, não a acolhida sem mais de sua reprimenda, mas a consideração e ponderação de sua justeza e razão, e que, se o seu crivo assim julgar, ele, com autonomia, acate e corrija-se. Isto é saber corrigir e, inversamente, saber sofrer a correção que porta a contradição do julgamento.

Agora, não se pode supor que a abertura para a contradição corretora assenta numa suposição de força que viria a triunfar no embate das razões de uma e outra parte. Supor a superioridade de força, supor que se irá com as melhores razões sobreviver ao ataque e sobrepassar as contrárias, é sinal claro de que se tem e assume presunçosamente um sentimento de preeminência e de desdém pelo outro que contradiz e corrige só visando um bem. Melhor assumir a perspectiva inferior do fraco, reconhecer que se pode estar em erro e falhar, corrigir-se humildemente. E daí preferir a companhia dos que maltratam, pois dela se pode tirar proveito com a correção. Em suma, saber sofrer a correção é saber abrir mão da vitória no assunto discutido, é saber vergar-se sob a força das razões do outro, é saber vencer-se a si mesmo neste reconhecimento da derrota. Verdadeiro sinal de superioridade, não da opinião ou conduta moral, mas da conduta intelectual e do julgamento que vê com isenção - não estando afetado pelo amor de si - e, com clareza, que o outro tem, na ocasião, melhores razões.

De resto, devemos considerar que em Montaigne o reconhecimento prévio da ignorância, operado já pelo ceticismo, inflete a finalidade da conversa para a questão da condução da busca. E o interesse se volta para a "forma". O obstinado (em seu autoritarismo e cólera) e o dissimulado (em seu servilismo mesclado de temor e esperança de proveito) não chegam, por seus caracteres e paixões, a estabelecer a "sociedade e familiaridade" que Montaigne elege como a boa conversa. No entanto seus desvios concernem à matéria. $\mathrm{O}$ obstinado, em sua temeridade, porque acredita ter uma opinião verdadeira sobre ela, descarta não a que o outro traria, mas aquela a que chegariam juntos pelo trabalho da contradição. O dissimulado, em sua covardia e interesse, aceita a verdade sobre ela, já pronta, do outro; descarta a que a sua correção e contradição pudessem trazer. Verdades precárias e provisórias, é certo; mas "verdades" que concerniriam a eles, não outra, mais ambiciosa, mas que não Ihes cabe possuir, nem, talvez, seria útil se possuíssem. Mas há uma 
outra espécie de erro que não diz mais respeito somente à relação com a matéria, nem com a verdade como causa comum, mas já é da "forma". Este é o erro do "tolo".

\subsection{A "forma" de conduta no debate: o imperativo da "ordem"}

Montaigne encerrava o passo anterior afirmando preferir ser maltratado a adulado, e ser vencido no debate pela força da razão do adversário a vencê-lo em função de sua fraqueza. A seqüência do texto fará suma dos pontos que ele estabeleceu no movimento precedente, cujo traço principal, poderíamos dizer, se define por uma relação com as matérias: "[B] [...] II me chaut peu de la matière, et me sont les opinions unes, et la victoire du subject à peu près indifferente" (III VIII, p. 925). Da perspectiva das "matérias" discutidas, das opiniões que são lançadas na conversa sobre elas e, no caso de disputa, da eventual vitória de sua opinião, Montaigne afirma aqui uma franca "despreocupação" (o verbo empregado nos sugere e remete a nonchalance montaigneana) e indiferença quase integral. Com isso, ele nos lembra não só a virtual universalidade de interesse dos que se entretêm em conference, como também, a possibilidade sempre aberta de ver refutada uma opinião de qualquer uma das partes, sem que isso deva vir a afetar ou ofender alguém. $A$ conference se inscrevendo num âmbito que iguala todas as proposições e as reduz ao domínio opinativo, instaura as condições de um livre exame, de uma busca desinteressada da verdade, e de um regime de entre-correção moral entre os amigos.

O problema, porém, com que se depara e que enfrenta diretamente a partir de agora, feita esta breve recapitulação, é o da "forma" de conduta do debate e de seus "modos". Mais acertadamente e nos termos da exposição par contrarieté que nos é oferecida, o da carência de forma dos "tolos". É certo que, em boa medida, a discussão até este ponto já se concentrava na "maneira" dos interlocutores se conduzirem na conversa e na disputa, pois a justa medida e "temperança" que habilitava Montaigne a sofrer rudemente as repreensões dos amigos é elemento que compõe a "retidão" de sua postura intelectual (já um elemento, portanto, de sua "maneira"). Mas tais disposições dependiam, todavia, fortemente da crítica do conhecimento que nutria seu anti- 
dogmatismo. Logo, de uma certa relação com as "matérias do dizer": era porque havia a "distância" instaurada pela experiência repetida da "suspensão" (o esvaziamento de um dos pratos da balança) que se podia aceitar e acolher as opiniões diversas sobre os assuntos e, no limite extremo, a contradição, sem cólera. Mas, no movimento que se inicia, não se trata mais da crença que mantemos na verdade do conteúdo de nossas proposições; ou, em outras palavras, não se trata mais de afastar - em nome da economia da relação exigida pela conversa - a crença que espontaneamente temos de que nossas opiniões traduzem a verdade acerca das coisas ou de nós mesmos, de que portam um valor e uma autoridade, simplesmente porque pressupomos ter mais "bom senso" e sermos capazes de distinguir tão bem o verdadeiro do falso, que nos irritamos quando contrariados. Não se vai a partir daqui avaliar as opiniões em sua relação com as coisas, para se afastar a pretensão e presunção de verdade dos discursos sobre elas, e com isso acertar a "postura" diante da "contradição". O que Montaigne agora investiga é a "forma" de conduta e comportamento dos interlocutores no debate, e as considerações se voltam inteiramente para o plano da manière. Voltemos, pois, a seguir os passos de Montaigne.

"[B] [...] En fin, je reçois et advoue toutes sortes $d^{\prime}$ atteinctes qui sont de droict fil, pour foibles qu'elle soient, mais je suis par trop impatient de celles qui se donnent sans forme" (id. ibid., grifos meus). Há pouco em nosso estudo deparamo-nos com a frase em que nosso autor ousadamente afirmava a sua "rendição" à verdade, não importando de que mãos ela viesse. Evidentemente, Montaigne de modo nenhum quer se fazer portador de uma verdade sólida o bastante para resistir a boas razões. Tampouco, coloca suas opiniões acima da "causa comum", como vimos. Este texto citado está em continuidade com aquela postura, mas situa o Ensaísta em meio ao debate, sofrendo o ataque de golpes nem sempre iguais. Notemos que, em uma disputa - referida aqui metaforicamente como "duelo" entre esgrimistas -, Montaigne distingue dois tipos de "golpes" ("atteinctes") assestados por seus adversários: os que são "de droict fil" e os que são "sans forme". O acerto não está na força, mas na retidão do golpe: ele é "droict". Teremos de esclarecer em que consiste esta retidão, bem como a ordem que ela permite articular. No entanto, não poderemos esperar uma "teoria" da ordem, que o texto não nos dá. Apenas uma breve 
imagem dela nos será oferecida, sendo que Montaigne se estende muito mais na apresentação do avesso dela, também por imagem, ao expor os desvios da tolice. Por enquanto, e de um modo impreciso ainda, adiantemos somente que no jogo entrecortado de falas breves de que se compõe a conversa, o desvio mais freqüentemente ocorre quando um dos interlocutores, ou ambos, perdem o fio do assunto para se voltarem aos cuidados do que é "inessencial": seja, por um lado, cuidar do incidental ou das palavras e frases que referem "suavemente" o assunto, em parte, comportamento já latente na figura do adulador; seja, por outro, passar a um ataque pessoal do oponente, a uma argumentação ad hominem, comportamento implicado na figura do erístico. É mantendo conjuntamente a atenção à matéria, porfiando no rastro das coisas, que se respeitará esta retidão que Montaigne põe como condição de sua paciência. Isto atesta o quão sutil é o conceito de "forma" ${ }^{34}$ mobilizado, pois se trata de uma noção que refere, não um mero cuidado formal, mas a destreza e habilidade que produzem a seqüência encadeada e ordenada de falas alternadas, as quais respeitam o "à propos", ou seja, respeitam as articulações da "matéria" que impõe, por ela mesma, a ordem conseqüente de tratamento do assunto. Voltemos.

A par da distinção da qualidade dos golpes há uma outra. Montaigne discerne duas acolhidas ou recepções: recebe ele mesmo pacientemente - é o que se supõe, mas logo dirá "pacificamente" ("paisiblement") - os primeiros; recebe assaz impacientemente os outros. Sem dúvida, estamos na presença de uma das manifestações, semeadas ao longo do capítulo, do vício em que incorre toda vez que encontra com um "tolo". Montaigne, mais do que reclamar, se irrita com um erro na conduta do debate: um modo, não fraco, mas errado

\footnotetext{
${ }^{34} \mathrm{O}$ termo, todavia, guarda não só sutileza como alguma ambigüidade. Pois, poderíamos pensar que se trata de voltarmos nossos cuidados e atenção para as "palavras" (verba) ao se depor, como resultado do ceticismo, o labor com as "coisas" (res), já que não cabe sondar a maior ou menor adequação das palavras às coisas, já que ser-nos-ia vedada, por falta de critério de escolha, toda aproximação de nossos pensamentos e idéias ao real em sua espessura, restando-nos o labor com palavras. No entanto, é importante lembrar, há um terceiro termo que se insinua nesta oposição entre palavras e coisas: o da significação das palavras e o do sentido das proposições. E mais, a exigência de ordem, que surgirá em breve, insistirá na constância do significado e no nexo que liga nossos enunciados: entender "o que" e "por que" se diz algo (Cf. ibid., p. 928, em que fala da atitude "tola" daqueles sob os quais tem poder: "Ils n'entendent ny ce qui se dict ny pourquoy [...]"). Se nosso pensamento não obtém garantias no que concerne à transcrição "formal" da estrutura do ser, a exigência de racionalidade migra para o plano da coerência e consistência do pensamento, e será traduzida pelo imperativo da "ordem".
} 
de golpear (de perguntar ou de responder, diga-se). As considerações deslizam para o plano da conduta: "Tout un jour je contesteray paisiblement, si la conduicte du debat se suit avec ordre. [C] Ce n'est pas tant la force et la subtilité que je demande, comme l'ordre" (Cf. id. ibid.). Ao lado da discreta nota que nos lembra que as discussões entre amigos não são medidas pelo tempo da clepsidra, como queria Platão, visto que a "contestação" não tem limite de tempo, Montaigne condiciona sua permanência "pacífica" no debate ao prosseguimento ordenado da sua conduta. E descarta duas outras qualidades dos "golpes", a "força" e a "sutileza", para que toda a demanda se volte para o que julga prioritário: a ordem. Com isso, dá-se um passo ainda tímido no esclarecimento do sentido dos golpes assestados "de droict fil": por meio deles é que a "conduta do debate se segue com ordem". Ora, se a conversa se compõe das alegações (perguntas ou respostas) das partes que disputam - os golpes ("atteinctes") são precisamente as falas contraditórias sobre o assunto lançadas no curso da contestação - sabemos, agora, que a sua retidão permite urdir um debate, cuja seqüência é ordenada. A conversa seguirá um curso ordenado, desde que as alegações ocupem seu "lugar", como elos que são nesta cadeia de discursos breves que tecem um maior; e elas o ocuparão, desde que atendam a determinadas condições que integram a qualidade reta do golpe e que ainda se vão discutir.

O texto nos diz imediatamente onde a ordem se encontra e onde não:

"[C] L'ordre qui se voit tous les jours aux altercations des bergers et des enfans de boutique, jamais entre nous. S'ils se detraquent, c'est en incivilité; si faisons nous bien. Mais leur tumulte et impatiance ne les devoye pas de leur theme: leur propos suit son cours. S'ils previennent l'un l'autre, s'ils ne s'attendent pas, au-moins ils s'entendent." (p. 925)

A presença da "ordem" parece apanágio antes do "rústico" e do "vulgo" que dos homens "instruídos e doutos", se aceitarmos que Montaigne se dirige a uma camada culta da sociedade francesa do séc. XVI, e se inclui nela. Nesta atribuição da "ordem" ao "rústico", àquele que carece exata e precisamente de "erudição", podemos apontar o prenúncio de uma crítica da "urbanidade e 
civilidade" do homem educado e formado nas Ciências e Letras, porém, carente da qualidade que tece a pertinência do discurso conduzido em comum, que é o da conversa. Aliás, num arremate de frase ("si faisons nous bien"), nem mesmo da acusação de incivilidade os cultos escapam. Mas é preciso fazer uma correção. Não que a "urbanidade" e a "civilidade" sejam descartadas. Só não é nelas que Montaigne assenta a qualidade principal da conversa. Já vimos como se volta contra os malefícios da adulação, em grande parte associados à civilidade e artifícios. Igualmente, não que a educação e a formação nas Ciências e Letras não sejam úteis. O problema surge do caráter que assume esta formação na relação com as autoridades do passado, assentadas na memória dos livros, e do uso que se pretende fazer das Ciências e Letras: servil ou liberal. Voltaremos a isso.

A rusticidade do "vulgo" é sim povoada de "tumulto e impaciência", qualidades incivis, mas não os "desvia do tema": o que foi previamente "posto" ("propos"), o que foi "proposto" para discutir, segue seu curso. O que se vê como qualidade nos "pastores e meninos de oficina", é que, se ao conversar, antecipam-se nas falas, não esperam sua vez, eles ao menos preservam, com a "ordem" (o não desviar-se do tema), o entendimento mútuo.

Depois desse breve contraste, Montaigne explicita finalmente o que concebe como o nexo que engendra a ordem na conversa: "On respond tousjours trop bien pour moy, si on respond à propos" (id. ibid.). Esta fórmula exprime o fundamental da noção de "ordre" que se demanda. É sobre o sentido desta expressão "respondre à propos" que temos de nos interrogar. Procuraremos colher na seqüência do arrazoado montaigneano elementos que nos permitam entendê-la e defini-la com mais clareza e precisão.

Ora, a fim de compreender o que está implicado nesta noção de "à propos", já podemos colher, neste breve esboço e imagem positiva que nos ofereceu da presença da ordem nos "simples e rústicos", dois elementos cruciais: em primeiro lugar, já ficou dito que a conversa não deve "desviar-se" do tema tratado, a fim de que o "proposto" siga o seu "curso", condição necessária e suficiente para que se mantenha o "entendimento" entre os interlocutores, para que falem uns com os outros e não sozinhos; e isto acontece se ambos se apegam ao assunto $e$ à ordem que ele constrangedoramente impõe. É preciso, pois, subordinar e submeter a 
"maneira" ou "forma", à "matéria" para que a conversa tenha ordem. Ainda que a matéria enquanto tal e as opiniões que se exprimem sobre ela sejam indiferentes, é nela que se espelha a ordem, é a partir dela que o discurso pode ser urdido com ordem, é a atenção a ela que evita que o discurso recaia num formalismo vazio, seja o da postura erística que emprega argumentos ilegítimos, seja o da postura dissimulada que assente ao falso e errôneo, seja ainda o da descompostura do "tolo" que não compreende nem "o que" se diz, nem "porque" se diz algo, como ainda veremos. As perguntas e respostas são "à propos" se e somente se atentam para as articulações da matéria tratada. Lembremos, no entanto, que não se trata nunca das coisas em si mesmas, das articulações da matéria tomadas como coisas em si mesmas, mas que migramos para o terreno das phantasíai, e que o importante agora é a significação dos termos, o sentido das proposições e o nexo que medeia e liga umas às outras. Em uma palavra, o problema agora é de "compreensão" 35 do peso e do nexo que liga as alegações de ambos interlocutores. Não estamos diante de um discurso que pretenda "descrever" formalmente as coisas. Até porque a perspectiva aqui é a de quem investiga e busca ainda - e, portanto, não sabe -, considerando os prós e contras sobre cada coisa ${ }^{36}$. E, por fim, em segundo lugar, é importante enfatizar, e isto nasce da própria menção ao "vulgo" e exclusão do "douto", que "ordem" aqui não significa, de modo nenhum, respeito à "civilidade" e à "urbanidade" que aguarde pacientemente sua vez de falar, observando regras que ditam boas maneiras no trato mútuo entre os homens. Aqui uma amabilidade no trato, mas de superfície, ou uma atitude "educada" que perca o fio ou desrespeite as articulações do tema tratado estão excluídas do "decoro" da conversação. Que não se confunda "ordre" com o tratamento afável, traço da conversa que facilmente desliza para

\footnotetext{
${ }^{35}$ Vale precisar que é de "compreensão" no caso do tolo, pois os erísticos e aduladores não são retratados como "ineptos". O defeito deles não se localiza na "inépcia" do "ato", mas na má "intenção", e no emprego de "meios" de argumentar ou de agenciar o discurso, aí sim formais e vazios, porém, eficazes, para obter o que desejam, vitória ou proveito. Aliás, o próprio Montaigne parece assim proceder, como veremos no prosseguimento imediato do texto, quando a disputa é "tulmultuada e sem regras", dizendo envergonhar-se depois.

${ }^{36}$ Teremos de voltar a isso quando nos depararmos com o tratamento negativo dado para o problema da ordem na exposição do rol de comportamentos tolos. Só adiantemos que esta habilidade e capacidade Montaigne remete seguramente a dois temas: o do saber do não saber, e o da "teste bien faicte" resultante do que concebe como o bom processo de "formação" (institution).
} 
a bajulação e evita as "repreensões" da disputa, nem com a civilidade e urbanidade dos salões ou da corte, parece nos avisar Montaigne.

A seqüência imediata volta a nossa atenção para a conversa em que a "ordem" está ausente e, sobretudo, para a atitude pouco pacífica do ensaísta frente a isso. No erro dos que disputam de modo "trouble et des-reglée" encontraremos o mote e a desculpa para que nosso autor deixe de tratar a "coisa" e passe a discorrer sobre a "forma", não sem antes nos advertir dos riscos de perversão da conference no apegar-se à forma. Vejamos:

"[B] Mais quand la dispute est trouble et des-reglée, je quitte la chose et m'attache à la forme avec despit et indiscretion, et me jette à une façon de debattre testue, malicieuse et imperieuse, dequoy j'ay à rougir apres." (id. ibid.)

"Confusão" e "desregramento" na disputa são o avesso da "ordem" assentada no "à propos" e impelem Montaigne ao desvio "despeitado e indiscreto" da "coisa" para a "forma", "lançando-o" a um modo ("façon") de "debater cabeçudo, malicioso e imperioso". O que está em jogo nesta mudança de atitude é o próprio domínio racional que tem sobre si mesmo e que habilita tanto à conversação ordinária e comum, na casa ou na corte, quanto às duras repreensões dos amigos ou ao exame racional das "coisas" - ao "quester ce qui est", como se verá -, que acontece na boa conference. Não é à-toa que acaba por assumir modos muito semelhantes aos do opiniastre que encontramos acima e sofre o mesmo páthos. Aquele também se deixava dominar pela "cólera" e não era capaz de portar-se racionalmente no debate. Somente os motivos são outros. Montaigne se indispõe com a "forma" errada de conduta do "tolo" ("sot"), fato que tem de lamentar, pois o arrasta a uma maneira igualmente errada, inconveniente e intempestiva, de conduzir-se, que depois o envergonha - ele diz "enrubescer" ("rougir"). Logo, o comportamento, desde já, é reconhecido refletidamente - isso é o que este pudor parece indicar - como erro importuno, como transgressão de um decoro imposto aos homens "discretos", e, mais adiante, será expressamente acusado por ele, como anunciou desde o início. Observemos, por ora, que este pudor, de certa forma, 
prenuncia que o juízo do Ensaísta é capaz de se desprender ${ }^{37}$ do erro implicado em sua própria atitude colérica ao acusá-la e extrair dela, ainda, uma justificação para o desvio e tratamento dos meios - no capítulo, bem entendido, e às suas expensas, pois exibe um erro seu que, aliás, diz ser incapaz de corrigir. O seu modo de tratar da manière du dire não se restringe à áspera $\mathrm{e}$ presunçosa acusação do erro de conduta do tolo, mas é matizada e atenuada pela auto-acusação de um outro, nele próprio, exposto na intenção de que os outros se corrijam, como já explicitava a análise do exórdio.

Continuando, Montaigne pondera a perda no trato com um "maistre si impetueux": "[C] II est impossible de traitter de bonne foy avec un sot. Mon jugement ne se corrompt pas seulement à la main d'un maistre si impetueux, mais aussi ma conscience" (id. ibid.). Como nos indica, ela é dupla: corrompese o julgamento, porque a disputa não progredindo com o foco nas "coisas", não se tem nem instrução, nem exercício, nem avanço no jogo de entrecorreção que a conversa ensejaria; e corrompe-se a "consciência" que peca em perder a "boa-fé" na lide com ele, o tolo.

Bem a propósito, Montaigne se lembra de que incorre num vício muito próximo daquele por meio do qual a postura erística, em sua "cólera" combativa, desvirtua a conference, e, por isso, sustenta, surpreendetemente para quem vinha fazendo o elogio desta última, que "nos disputes devoient estre defendues et punies comme d'autres crimes verbaux". Porém, o que está verdadeiramente em causa, neste retorno à cena da disputa erística por associação às observações sobre a impossibilidade de se tratar de "boa-fé" com o "tolo", é uma potência latente e destrutiva, não da tolice em sua confusão e desregramento, mas da "habilidade em disputar" que, em sua hýbris, arrisca a própria sociedade dos homens, suas repúblicas, assentadas na "amizade" que une seus membros pela causa comum da "verdade":

"[C] [...] Quel vice n'esveillent elles [sc. noz disputes] et n'amoncellent, tousjours regies et commandées par la cholere! Nous entrons en inimitié, premierement

\footnotetext{
${ }^{37}$ Tal separação e isenção do juízo em relação às afeições são magistralmente fixadas num famoso passo do De l'experience: "[B] [...] Le jugement tient chez moy un siege magistral, au moins il s'en efforce soingneusement; il laisse mes appetis aller leur trein, et la haine et l'amitié, voire et celle que je me porte à moy-mesme, sans s'en alterer et corrompre. S'il ne peut reformer les autres parties selon soy, au moins ne se laisse il pas difformer à elles: il faict son jeu à part." (III XIII, p. 1074).
} 
contre les raisons, et puis contre les hommes. Nous n'aprenons à disputer que pour contredire, et, chascun contredisant et estant contredict, il en advient que le fruit du disputer c'est perdre et aneantir la verité. Ainsi Platon, en sa republique, prohibe cet exercice aux esprits ineptes et mal nays." (id. ibid., p. 926)

A "façon" desviante de Montaigne diante da tolice o leva a um comportamento nada benévolo que confina muito estreitamente com a disputa pelo simples gosto da contradição que aparece neste passo, algo que põe a perder e aniquila a "verdade" que se devia buscar, algo que afasta os interlocutores da "causa comum". O que está no horizonte, vê-se claramente agora, é a perda dos laços de amizade que unem os homens entre si, pelo avanço do ódio e inimizade que a contradição, em sua negatividade puramente formal, pode engendrar. O que impossibilita o trato de "boa-fé" é o esquecimento da "causa comum", mais uma vez, e o apego à pura forma, seja no encontro e embate de "hábeis" (porém, não "benévolos"), seja no encontro entre os que, embora "habéis" na disputa com os "esprits vigoureux et reiglez", mostram-se "inábeis" no encontro com o "tolo". Se Montaigne concorda com Platão, neste passo, em que a conversa deve ser proibida aos "espíritos ineptos e mal-nascidos", é porque, antes de tudo, se não houver uma prévia avaliação da "qualidade" da alma com que se defronta em conversação, para só depois pôr-se na busca da verdade com ela - no caso de se ter estabelecido que vale a pena fazê-lo, bem entendido -, corre-se sempre o risco de perder o que se buscava. Resta saber se ele mesmo não se enquadra entre os "ineptos e mal-nascidos", já que se deixa arrastar e irritar com a "tolice". A resposta sutil a esta questão virá mais adiante.

Vemos, então, que, do ponto de vista da economia do discurso, se construiu neste último movimento uma espécie de justificativa para o desvio e o tratamento do problema da manière. Deste modo, lembrando expressamente a pergunta socrática pela essência ("quester ce qui est"), Montaigne pede licença para desviar-se do assunto ("subject") e ver "le moyen de le traicter", advertindo que não se tratará de "meio escolástico e artificial", mas de "meio natural, de um são entendimento":

"A quoy faire vous mettez vous en voie de quester ce qui est avec celuy qui n'a ny pas ny alleure qui vaille? On ne faict poinct tort au subject, quand 
on le quicte pour voir du moyen de le traicter; je ne dis pas moyen scholastique et artiste, je dis moyen naturel, d'un sain entendement." (III viii, p. 926)

Fica claro desde já que a intenção de Montaigne não é a de expornos um conjunto de regras e estratégias - de resto, para ele "escolásticas e artísticas" -, por meio das quais o exercício conjunto de pensamento da conference se faria. De forma nenhuma nos é oferecido um órganon, ou uma tópica, ou ainda, o que Descartes fará no séc. XVII, "regras para direção do engenho". Montaigne se atém a balizar este exercício por meio de "advertências" e ensina mais a evitar certos escolhos e erros, e sondar certas "imposturas", do que a operar com "formas" vazias de argumentar ou preceitos para a produção dos discursos. O "meio natural, de um são entendimento", de que a "ordem" e o "à propos" são, juntamente com a "prudência", os principais elementos, assenta em um desempenho que a lógica e as letras só fazem corromper. Mas não devemos entender as operações do "são entendimento" como a pura expressão da boa e bela "natureza" dos "bem nascidos", pois isto desprezaria a outra componente desta "faculdade", construída e formada pelo processo de institution, que faz desta boa natureza uma "teste bien faicte". O que Montaigne critica nas Letras e nos procedimentos formais da disputa (não esqueçamos a crítica que os humanistas movem contra a disputatio medieval, e a reforma por que passava a Dialética no séc. XVI, por obra de, sobretudo, de Petrus Ramus), não são as regras ou preceitos enquanto tais, mas o apego servil às regras e preceitos, a cultura da imitação servil, por oposição à imitação rival (aemulatio) de que a justa que encontramos no início de nossa discussão já dava notícia. Ao conversar e ao ler sua postura é a mesma: de atenção à "maneira" e aos juízos. Montaigne exprime seu descontentamento com a cultura da memória em muitos passos do De l'art de conferer, bem como ao longo de todos os 3 livros dos Ensaios, pois nela se apóia o saber de empréstimo que é objeto de sua enfática recusa. E se descreve como homem sem memória, num grau prodigioso, acentuando em si o traço que the interessa: o jugement. Todo processo de educação que nos descreve no De I'institution des enfans visa a formação da capacidade crítica do julgamento, e organiza o seu curriculum, baseado, sobretudo, nas freqüentações dos homens e dos livros, neste sentido. 
Isto posto, não esperemos um tratamento "positivo" do problema dos "moyens" que produzem a "ordem" na conduta do debate. Na seqüência, ele nos instruirá sempre negativamente sobre isto, elencando um rol de impropriedades e impertinências que os "espíritos baixos e doentios", "ineptos e mal-nascidos", produzem ao tentar conversar.

Passemos, então, a essas lições par contrarieté, em busca de uma maior precisão do que seja a "ordem" e tentemos ler a imagem que nos oferece. O que se passa afinal com os tolos? Montaigne alude, em primeiro lugar e de maneira mais geral, a um movimento tempestuoso em direções contrárias que se desgarra do que trata e perde o que buscava:

"[B] [...] Que sera-ce enfin? L'un va en orient, I'autre en occident; ils perdent le principal, et l'escartent dans la presse des incidens. Au bout d'une heure de tempeste, ils ne sçavent ce qu'il cerchent; I'un est bas, I'autre haut, l'autre costié" (id. ibid.)

O arremate final refere exatamente uma imagem do "alvo" que não se atinge, tomada ao tiro com arco e flexa, como nos esclarece Villey nesta passagem ${ }^{38}$. E erram o alvo, precisamente porque tomam direções contrárias ao voltar seus cuidados para o incidental ("des incidens"), ou seja, deixam a matéria tratada ser atravessada por uma "multidão" de elementos que incidem de fora nela, perdendo e descartando o principal. Daí o tumulto do aleatório e fortuito - referido aqui pela tempestade resultante deste andar desencontrado que os leva, em pouco tempo, a já não saber o que buscavam. Não se trata exatamente de não tomar, de início, uma matéria comum, mas de não visar o mesmo ao tratá-la, de perder o que se buscava, por se terem desviado para o incidental, o que está à margem ou fora dela. O problema, no espírito do tolo, está em sua incapacidade de manter a atenção no núcleo do assunto. Eles deixam de tratar da mesma coisa. A exigência anterior de "contradição dos julgamentos" da boa conference obrigava a falar da mesma coisa, mas não dizer a mesma coisa dela, ou melhor, que dissessem coisas contraditórias. $\mathrm{O}$ tumulto dos "bergers et enfans de boutique" era, igualmente, de outra ordem, pois sua atenção se mantinha no assunto que seguia seu curso. Aqui, já não se

${ }^{38}$ Cf. n. 7, na edição Villey-Saulnier dos Ensaios. 
fala da mesma coisa, que se perdeu no tumulto da atenção que se desviou. Por isso desgarram-se um do outro e perdem a coesão da interlocução. Mas, o que garantiria esta coesão, no curso das objeções e respostas, se não estivessem a falar da mesma coisa (res), e passassem a atentar para o que nela é "incidental"? Deixam de falar um com o outro, porque passam a falar de coisas diferentes.

Depois e de modo mais minudente, ele lista dez comportamentos tolos:

\begin{abstract}
"Qui se prend à un mot et une similitude; qui ne sent plus ce qu'on luy oppose, tant il est engagé en sa course; et pense à se suyvre, non pas à vous. Qui, se trouvant foible de reins, craint tout, refuse tout, mesle des l'entrée et confond le propos; [C] ou, sur l'effort du debat, se mutine à se faire tout plat: par une ignorance despite, affectant un orgueilleux mespris, ou une sottement modeste fuite de contention. [B] Pourveu que cettuy cy frappe, il ne luy chaut combien il se descouvre. L'autre compte ses mots, et les poise pour raisons. Celuy-là n'y emploie que l'advantage de sa voix et de ses poulmons. En voilà qui conclud contre soy-mesme. Et cettuycy, qui vous assourdit de prefaces et digressions inutiles. [C] Cet autre s'arme de pures injures et cherche une querelle d'Alemaigne, pour se deffaire de la societé et conference d'un esprit qui presse le sien. [B] Ce dernier ne voit rien en la raison, mais il vous tient assiegé sur la closture dialectique de ses clauses et sur les formules de son art." (id. ibid.)
\end{abstract}

O que esta lista nos apresenta são, claramente, "contra-exemplos" de conduta, oferecidos pelo comportamento de tolos de vária espécie. Nela encontramos: 1) os que se prendem a palavras ou figuras (similitudes); 2) os que seguem um caminho próprio, sem dar atenção ao que se lhe opõe; 3) os que se acham fracos, misturando e confundindo o assunto no início; ou, tendo entrado no debate, acabam por se calar, afetando desprezo; 4) os que atacam sem preocupação de que, com o ataque, se descubram; 5) os que levam em conta o número das palavras, ou seja, o quanto falam, não o que falam, tomando a quantidade de palavras por razões (falam muito, dizem pouco, não observam a brevidade); 6) os que gritam (a razão assentaria na intensidade da voz); 7) os que se contradizem; 8) os que se prendem ao acessório (prefácios e digressões que não servem para nada); 9) os que se armam de injúrias (ataques pessoais) ou buscam uma querela sem propósito para escapar 
(subterfúgio para evitar a pressão do debate); 10) o dialético que, não vendo nada na razão, sitia com as costuras de suas cláusulas e as fórmulas de sua arte (vazio das formas de argumentação). Não podemos passar em silêncio que Montaigne reúne nesta lista e sob o mesmo traço, que, daqui a pouco, ficaremos sabendo que entra na composição do caráter daquele que atente pelo nome de "sçavant" ou "maistre ès arts", idêntico para o Ensaísta ao de "pedante", figuras que embaralha tranqüila e divertidamente, pois aqui os mestres da disputa dialética irmanam-se aos retores, participando ambos da mesma inépcia. Não tentaremos, contudo, extrair, a todo custo, o traço comum que reúne todos estes comportamentos. Nem a intenção de Montaigne -assim acreditamos - ao apresentar esta lista, seria a de nos levar a induzir um "tipo" muito claro e bem definido. Mas há um traço que não podemos deixar de notar e que se coaduna com a crítica que irá mover mais adiante contra o uso servil das ciências: a falta de cuidado com as matérias, com as concepções, concomitante ao desvio para o cuidado com a "forma". Pois, em suma, o que todas estas imposturas denunciadas apresentam é um desvio da matéria tratada, do assunto da conversa ou da contenda, seja por recusa expressa ou algum subterfúgio, seja por uma atenção indevida a um formalismo tagarela. Efeitos resultantes de certa "indigestão" intelectual que a análise das causas desta impostura tornará explícita.

Nosso autor passa, então, a um excurso em que apresenta o "diagnóstico" deste estado de coisas. Por que tanta descompostura e tolice? A resposta a isto nos dará ensejo para a discussão da acerba crítica que Montaigne dirige contra as "ciências" e do uso "pedante" e "servil" que delas se faz, como já adiantamos ${ }^{39}$.

Montaigne começa enunciando a desconfiança quanto ao proveito para a vida que se poderia tirar das "ciências", em especial das que prometem ensinar a melhor pensar e discorrer. Embora a citação de Sêneca no acréscimo [C] mencione "letras", o seu alvo é mais claramente a "lógica", que não ensina nem a melhor viver, nem a melhor discorrer, segundo a outra opinião autorizada que ele traz em acréscimo, de Cícero:

\footnotetext{
${ }^{39}$ As considerações que seguem nos remetem a dois capítulos fundamentais (aliás, não só se seguem um ao outro no primeiro livro, como também possuem unidade de questão - 0 segundo prossegue e aprofunda as considerações do primeiro), para a compreensão desta crítica: o I XXv, Du pedantisme e o I XXVI, De l'institution des enfans.
} 
"[B] [...] Or qui n'entre en deffiance des sciences, et n'est en doubte s'il s'en peut tirer quelque solide fruict au besoin de la vie, à considerer l'usage que nous en avons: [C] nihil sanantibus litteris? Qui a pris de l'entendement en la logique? où sont ses belles promesses? [C] $\mathrm{Nec}$ ad melius vivendum nec ad commodius disserendum." (id. ibid.)

Sabemos que das três escolas do período helenístico da filosofia grega a que mais desprezou esta que é uma das três partes em que se divide a filosofia - segundo uma partição que remonta talvez a Platão, e que se fixou claramente com a Stoa, a saber, lógica, física e ética - foi o Jardim de Epicuro, que a excluiu totalmente. Montaigne realmente se insurge rudemente ("Voit-on plus de barbouillage au caquet des harengeres qu'aux disputes publiques des hommes de cette profession", id. ibid.), ao que parece se alinhando àquele desprezo, contra as regras que pretendem dirigir artificialmente o pensamento e o raciocínio, preferindo as "tavernas" às "escholes de la parlerie" - mais uma vez o "vulgo" tem a prerrogativa da manière - para que os filhos aprendam a falar. E desafia que se tome um "maistre ès arts" para conversar ("conferer"), para testar se sua "competência" - ele é "sçavans" - faz dele alguém menos "inepto".

"[B] [...] Ayez un maistre és arts, conferez avec luy: que ne nous faict-il sentir cette excellence artificielle, et ne ravit les femmes et les ignorans, comme nous sommes, par l'admiration de la fermeté de ses raisons, de la beauté de son ordre? que ne nous domine-il et persuade comme il veut? Un homme si avantageux en matiere et en conduicte, pourquoy mesle-il à son escrime les injures, l'indiscretion et la rage? Qu'il oste son chapperon, sa robbe et son latin; qu'il ne batte pas nos aureilles d'Aristote tout pur et tout cru, vous le prendrez pour l'un d'entre nous, ou pis. II me semble, de cette implication et entrelasseure de langage, par où ils nous pressent, qu'il en va comme des joueurs de passe-passe: leur soupplesse combat et force nos sens, mais elle n'esbranle aucunement nostre creance; hors ce bastelage, ils ne font rien qui ne soit commun et vile. Pour estre plus sçavans, ils n'en sont pas moins ineptes." (id. ibid., p. 927)

O desprezo testemunhado pelo "maistre ès arts" continua na acusação de que busca impressionar não com a firmeza de suas razões ou a 
beleza de sua ordem, mas com uma "excelência artificial", que mescla "injúria, indiscrição e raiva" à sua "esgrima". Desafia-o, então, a despir a indumentária de doutor e o latim e não atormentar nossos ouvidos com Aristóteles nu e cru: ele se mostraria igual aos outros ou pior. A alusão ao Estagirita claramente confina nosso "mestre em artes" nos muros da escola, e a crítica centra seu foco em suas "disputas" artificiais. O que critica, por um lado, é seu dogmatismo indigesto, a sua pura aceitação do dogma, alegado como verdade imbatível e inquestionável. Por outro, é o próprio enrijecimento das regras da disputatio que questiona. Quanto a este ponto, emprega uma analogia entre a linguagem destes mestres e os jogadores de "passe-passe", ou seja, acusa-os expressamente de forjar, com o discurso, sofismas. Tais prestidigitações produzem apenas ilusão de prova, pois, assentando numa lógica puramente aparente, esta "soupplesse" combate e força apenas os "sentidos", mas não abala a "crença". Se abandonarem esta "bastelage" ("aparato inútil, vazio"), não fazem nada que não seja "comum e vil". Nomeia-os, enfim, por "sçavans", qualificando-os de ineptos.

Observemos que, a pecha de sofística, de uma lide insidiosa com o discurso, porque solidária de um logro e da produção de uma ilusão por meio de formas ilegítimas do raciocínio, recai, neste passo, justamente sobre a Escolástica, que é a depositária da doutrina que talvez mais se tenha dedicado a desfazer tais ilusões argumentativas, tendo dispensado grande esforço no desenvolvimento da lógica e ensinado sobejamente a combater e refutar os sofismas. Todavia, o endereço mais claro desta crítica é o "especialista" nas disciplinas do trivium (com sua gramática, sua dialética e sua retórica), sábios competentes cuja "ciência" não faz nem que falem bem (sua tarefa expressa), muito menos que vivam bem, nem os cura de sua tolice. Sua relação com as letras, com os saberes depositados nelas é falha, pois elas não os tornam melhores. Eles estão mais próximos dos historiadores - de que ainda se falará -, que apenas guardam na memória coisas úteis do que de homens de entendimento e juízo. Não pertencem ao número das "testes bien faictes" para Montaigne. A ciência para eles não serviu para formar o "jugement". São antes pedantes. 
Entretanto, matiza prudentemente seu juízo sobre o "saber"40 ("sçavoir") e aqueles que o possuem, lembrando que ele pode ter um "vray usage", sendo assim a "mais nobre e poderosa aquisição dos homens"(Cf. id. ibid.: "[B] [...] J'ayme et honore le sçavoir autant que ceux qui l'ont; et, en son vray usage, c'est le plus noble et puissant acquest des hommes.") Porém, logo se volta mais uma vez raivosamente contra os "pedantes", no seu entender, numerosíssimos em seu século, que assentam sua "suffisance et valeur" no "sçavoir" (na "ciência"), que "submetem seu entendimento à memória", e não sabem nada senão por livros:

"[B] [...] Mais en ceux là (et il en est un nombre infiny de ce genre) qui en establissent leur fondamentale suffisance et valeur, qui se raportent de leur entendement à leur memoire, $[\mathrm{C}]$ sub aliena umbra latentes, $[\mathrm{B}]$ et ne peuvent rien que par livre, je le hay, si je l'ose dire, un peu plus que la bestise." (id. ibid.)

No cerne da acusação o uso "servil" das "ciências", o "comércio" ou "tráfico" dos "saberes": "[B] [...] En mon pays, et de mon temps, la doctrine amande assez les bourses, rarement les ames". E conclui, pela "qualidade indiferente" da ciência, que depende em tudo da alma que nela se imiscui:

"[B] [...] Si elle les [sc. les ames] rencontre mousses, elle les aggrave et suffoque, masse crue et indigeste; si desliées, elle les purifie volontiers, clarifie et subtilise jusques à l'exinanition. C'est chose de qualité à peu pres indifferente; tresutile accessoire à une ame bien née, pernicieux à une autre ame et dommageable; ou plustost chose de tres precieux usage, qui ne se laisse pas posseder à vil pris: en quelque main, c'est un sceptre; en quelque autre, une marotte." (id. ibid.)

O saber é coisa de qualidade "quase indiferente". Isto é, depende de que uso se faz dela, não sendo, em princípio, nem boa nem má. Só é um bem

\footnotetext{
${ }^{40} \mathrm{Da}$ mesma forma o Ensaísta exprime, na abertura de sua Apologia, certo respeito distanciado em relação às ciências: "[A] C'est, à la verité, une tres-utile et grande partie que la science, ceux qui la mesprisent, tesmoignent assez leur bestise; mais je n'estime pas pourtant sa valeur jusques à cette mesure extreme qu'aucuns luy attribuent, comme Herillus le philosophe, qui logeoit en elle le souverain bien, et tenoit qu'il fut en elle de nous rendre sages et contens: ce que je ne croy pas, ny ce que d'autres ont dict, que la science est mere de toute vertu, et que tout vice est produit par l'ignorance. Si cela est vray, il est subject à une longue interpretation." (II XII, p. 438).
} 
para quem sabe manejá-lo e o emprega em seu uso correto ${ }^{41}$. Para os outros, os que não são "bien nées" é "pernicioso e perigoso". Ou, por outra, cioso de seu valor, não se deixa possuir por "preço vil". Nesta relação servil, dependendo da qualidade inicial da alma observamos dois desenvolvimentos na relação com a doutrina ("doctrine"): para os "mousses" (="obtusos"), ela, massa crua e indigesta, pesa e sufoca; para os "desliées" (="sutis"), as apura à seu bel prazer, clareia e sutiliza até a "exinanição" (= "dissolução"). Uns e outros são, de certo modo, deformados por ela. Em suma, o verdadeiro uso, deve atender a estas duas condições: 1) depende da qualidade da alma, e 2) depende de que não se faça uso servil. Notemos, porém, que, mesmo em seu uso verdadeiro, o saber é ainda, aos olhos de Montaigne, "acessório muito útil", ele nunca ocupa o lugar principal, o centro, embora tenha sido qualificado de "plus noble et puissant acquest des hommes".

Terminada nossa discussão deste excurso em que vitupera o uso das ciências, voltemos ao fio do ensaio que estamos comentando. Montaigne volta ao problema do sentido que pode ter a vitória no combate, e nele insere o problema da "ordem":

"[B] [...] Quelle plus grande victoire attendez vous, que d'apprendre à vostre ennemy qu'il ne vous peut combatre? Quand vous gaignez l'avantage de vostre proposition, c'est la verité qui gaigne; quand vous gaignez l'avantage de I'ordre et de la conduite, c'est vous qui gaignez." (III VIII, p. 927)

Este texto interpela um suposto "leitor" em sua "esperança" ou "expectativa" de vitória. O Ensaísta opera aqui uma distinção entre duas vitórias possíveis no horizonte dos que entram em combate: uma maior e outra menor. A menor põe-se no plano da "razão" e da "verdade" - relativas, como já

\footnotetext{
${ }^{41}$ Formula o mesmo juízo, ao dirigir-se a condessa de Gurson, na missiva que lhe endereça no proêmio do De l'institution des enfans (Cf I XXVI, p. 149: "[A] Madame, c'est un grand ornement que la science, et un util de merveilleux service, notamment aux personnes élevées en tel degré de fortune, comme vous estes. A la verité, elle n'a point son vray usage en mains viles et basses. Elle est bien plus fiere de préter ses moyens à conduire une guerre, à commander un peuple, à pratiquer l'amitié d'un prince ou d'une nation estrangiere, qu'à dresser un argument dialectique, ou à plaider un appel, ou ordonner une masse de pillules".)
} 
firmamos acima - que vêm aderir às "proposições" e "teses" que uma ou outra das partes defendem. Por outras palavras, quando venço porque tenho razões mais fortes, porque estou com a "verdade", porque a tese do meu inimigo e as razões que a sustentam são mais fracas que as minhas, ou quando obtenho dele uma contradição ou a confissão de que se enganou, de que estava em erro, literalmente não venço, mas vence a "causa" que sirvo e apóio, a tese que sustento, a "verdade", em suma, da minha proposição. Há, contudo, uma distância entre mim e esta "verdade", ainda que seja eu a sustentá-la. Se em meu pensamento, se em minha opinião estou com a verdade ou coincido com ela, não posso, todavia, fazê-la minha. Devo compartilhá-la com meu interlocutor, eu que somente tive a felicidade de que a minha posição prevalecesse no debate, sendo não mais que um "suporte" para ela. Disto resulta apenas que a "verdade" - sempre no sentido provisório de um consenso relativo e momentâneo - acerca do tema debatido é esclarecida no confronto das teses, que se obtém para ela um discurso que é "verdadeiro", ou ao menos um que se mostrou suficientemente forte para suportar a contradição e o exame. Ela é, por assim dizer, uma vitória do objeto.

A maior vitória, por sua vez, não é do objeto. Pois ela pode se dar mesmo quando se perde a vantagem da proposição, mesmo quando se é refutado. Agora, a lição que se dá ao inimigo é de "ordem e conduta" no tratamento das matérias, qualidades que aderem - diferentemente da verdade, atributo da proposição - inteiramente ao sujeito, sendo, como são, atributos seus. O proveito que se pode obter da "conversação" se vê, assim, nitidamente referido por Montaigne ao ordenamento da conduta dos sujeitos que entram em disputa, não num possível esclarecimento da verdade das matérias debatidas. Ordenamento de conduta ou "maneira" que ela, para ser proveitosa, não só pressupõe, mas também exercita. Pois em grande medida o que a conversa deve produzir é a correção mútua da "impertinência" dos homens, como nos ensinará o acréscimo de 1588 na seqüência do texto, que elucida a tarefa que em Platão e Xenofonte é assumida, segundo Montaigne, por Sócrates:

"[C] II m'est advis qu'en Platon et en Xenophon Socrates dispute plus en faveur des disputants qu'en faveur de la dispute; et, pour instruire Euthydemus et Protagoras de la connoissance de leur impertinence plus que de l'impertinence de leur art. II 
empoigne la premiere matiere comme celuy qui a une fin plus utile que de l'esclaircir, assavoir esclaircir les esprits qu'il prend à manier et exercer." (id. ibid., p. 927-8)

Continua válido dizer que nossa proposição sofre derrota ao sermos refutados, mas a "maiêutica" - se nos for concedida a licença de empregar o termo - que aflora no passo que ora comento leva apenas ao reconhecimento da ignorância particular e da impertinência dos "esprits" manejados e exercitados por Sócrates. Ao alegar que Sócrates disputa mais em favor dos "que disputam" do que da disputa, e para instruir do conhecimento da impertinência (tolice) dos seus interlocutores, mais do que da impertinência da arte que professam, o texto já demonstra o desvio de atenção das matérias para a maneira. Já não se trata de ensinar que a tese sustentada não dá conta de e não responde ao problema que se pôs no início do debate. Sócrates ensina a "impertinência" deles, ou seja, sua tolice e desordenação, ainda que elas possam vir acompanhadas de erros ou acertos quanto à matéria. Mas é interessante lembrar que pode ser tolo tanto quem diz a verdade quanto quem diz a falsidade (Cf. id. ibid., p. 928: "Autant peut faire le sot celuy qui dict vray, que celuy qui dict faux"). Este Sócrates já não ensina o erro de opinião sobre as matérias, realizando o parto que traz à luz aquele que irá engajar-se no estudo das realidades verdadeiras, mas o que imporá ao espírito a exigência de ordenação, de conduzir bem a "caçada". O reconhecimento da ignorância torna-se aqui reconhecimento da falta de "à propos", e o que medirá o valor de um homem não será jamais a posse da verdade, mas a "ordem", a "prudência", a "suffisance".

Mas o deslocamento, para quem sabe sofrer a contradição e a derrota sem encolerizar-se, para quem sabe "estender suas armas vencidas ao ver a verdade, de longe, se aproximar", porta uma outra lição. A lição mais substancial está em reconhecer - por isso, mais uma vez, Sócrates disputa em favor dos disputantes para mostrar-Ihes não a "impertinência da arte", mas deles mesmos -, não um erro particular, mas a constante e universal possibilidade de erro para nós, e naquilo que mais nos interessa. Disso nos instrui muito claramente um passo de outro capítulo fundamental dos Ensaios em que afloram as lições da contradição, que seguramente podemos transpor 
do âmbito de um capítulo para o conjunto da obra, pois é traço constante do pensamento do ensaísta. Falo do ensaio III XIII, De l'experience:

\begin{abstract}
"Quand je me trouve convaincu par la raison d'autruy d'une opinion fauce, je n'apprens pas tant ce qu'il m'a dict de nouveau et cette ignorance particuliere (ce seroit peu d'acquest), comme en general j'apprens ma debilité et la trahison de mon entendement; d'où je tire la reformation de toute la masse. En toutes mes autres erreurs je faits de mesme, et sens de cette reigle grande utilité à la vie. Je ne regarde pas l'espece et l'individu comme une pierre où j'aye bronché; j'apprens à craindre mon alleure par tout, et m'attens à la reigler. [C] D'apprendre qu'on a dict ou faict une sottise, ce n'est rien que cela; il faut apprendre qu'on n'est qu'un sot, instruction bien plus ample et importante." (p. 1074)
\end{abstract}

A lição é transparente: não se trata de aprender um erro particular (julgava mal a respeito de algo, então, me corrijo neste, e somente neste ponto), mas de aprender em geral a "debilidade e traição do entendimento" (que aplicado a quaisquer outras matérias e considerando quaisquer outros objetos, pode estar ou vir a estar em erro), o que permite a "reformação de toda massa". Se o erro fosse considerado apenas da matéria, e desta matéria em particular, o sujeito de conhecimento poderia continuar confiante e seguro de seus outros "conhecimentos". No entanto, a desconfiança se volta para a "falculdade" de conhecimento - o "entendimento" - e, daí, para a sua aplicação a quaisquer matérias. Se o erro encontra-se antes no "instrumento" de conhecimento do que no resultado errado a que ocasionalmente chegou, podemos ampliar a advertência e a desconfiança. Por que não pensar que erramos a cada vez que o empregamos, se fomos traídos tantas e tantas vezes. Mas o que legitimaria a universalização do erro de aplicação e de operação de nossa faculdade de entendimento? Por que seria válido afirmar, tendo passado algumas vezes pela experiência particular do erro, a tese geral da falibilidade desta faculdade, e dizer com Sócrates que ao menos isto ele sabe: "nada sei"? É possível, para o filósofo que cunhou para si a moeda portando a divisa "Que sais-je?", afirmar, como verdade universal, a tese negativa da "inapreensibilidade", como regra aplicável a todos os casos? Montaigne talvez evite a afirmação, negativa por certo, desta tese, apenas por fazer dela não uma verdade geral, mas uma advertência geral da experiência 
que faz de si mesmo. Ela é apenas lembrança e consciência do erro passado, sem totalizar seguramente sobre o conteúdo atual ou futuro de nossas representações, o que seria uma operação dogmática ${ }^{42}$.

Com isso chegamos, por fim, ao momento mais elevado da exposição sobre a questão do imperativo da "ordem" e de sua razão mais profunda. Vale citar na íntegra o passo, pois, teremos de comentá-lo:

"[B] L'agitation et la chasse est proprement de nostre gibier: nous ne sommes pas excusables de la conduire mal et impertinemment; de faillir à la prise, c'est autre chose. Car nous sommes nais à quester la verité; il appartient de la posseder à une plus grande puissance. Elle n'est pas, comme disoit Democritus, cachée dans les fons des abismes, mais plustost eslevée en hauteur infinie en la cognoissance divine. [C] Le monde n'est qu'une escole d'inquisition. Ce n'est pas à qui mettra dedans, mais à qui faira les plus belles courses." (III VIII, p. 928)

Como se vê, Montaigne assume de modo transparente aqui, valendo-se da metáfora tradicional da caça ("chasse"), que a tarefa propriamente humana ("proprement de nostre gibier") é de busca da verdade ("quester la verité"). Temos a confirmação mais segura de que a conference é busca - nela é que se busca o que é ("quester ce qui est") -, ao menos uma modalidade dela. Mas não nos cabe a posse da "presa" ("faillir à la prise, c'est autre chose"). Posse que, discordando e corrigindo o pagão Demócrito, remete a Deus, pois pertence a uma "plus grande puissance", encontra-se "elevada a uma altura infinita no conhecimento divino". Por isso o "mundo" não é, para o homem, que é fraco para querer tomar posse dela, senão "escola de inquisição": a incumbência e tarefa ("gibier", que também significa "caça" e que se emprega aqui como as coisas que são do interesse e da alçada de alguém, desejadas e procuradas por alguém) é a de "inquirir", "questionar", "perguntar", "investigar" (ação que uma "dialética", enquanto arte do diálogo ${ }^{43}$, sempre

\footnotetext{
${ }^{42}$ A operação de generalização, de um caso particular a todos os casos possíveis, só pode ocorrer devido, por assim dizer, a esta transferência do ônus do erro à faculdade de conhecimento. Ao final do processo de esclarecimento dos espíritos eles conhecem, sim, aquela ignorância particular, mas ao mesmo tempo, e isto é mais importante, a própria debilidade, a própria imbecillitas. (Cf. ScoRAlick, A. "Experiência e Moralidade no último dos Ensaios de Montaigne", Dissertação (Mestrado), inédita, Faculdade de Filosofia, Letras e Ciências Humanas, USP, 2008, p. 13 ss.)

${ }^{43}$ Pensamos, antes, em uma obra como os Tópicos de Aristóteles do que propriamente numa "arte do diálogo" tal como a que veio a florescer com os scriptores artium entre os séc. XI e XIII
} 
tivera a intenção de teorizar e ensinar, mas que Montaigne desqualifica, em seu desprezo pela Lógica e pelo formalismo das disciplinas do trivium, assaz pedantes e professorais, em nome do exercício do são entendimento de que é capaz uma "teste bien faicte"). Mas não a de chegar à resposta. È escusável, para nós, que não se chegue a ela. Mas não o é do mesmo modo no que diz respeito à conduta: "não somos desculpados por conduzir a busca mal e impertinentemente". E na imagem tomada aos torneios medievais que fecha a citação o Ensaísta dá claramente a palma, não a quem acerta o alvo ("mettra dedans"), mas a quem faz "a corrida mais bela".

Então, nos cabe buscar, ou melhor, bem buscar, não possuir. A precisão de que se trata de uma busca com correção, que segue um padrão de conduta ordenada, pertinente, bela (são "belles courses" que se exigem), qualidades de que a "maneira" até aqui se reveste, é central. Tendo deslocado os cuidados e o zelo com o discurso - aquele que se tece em comum na conversa -, da adequação, dogmática, suposta que este manteria com as próprias coisas, para o de sua ordenação interna, para a ordem das concepções, noções - em uma palavra, das phantasiaí - que se ligam umas às outras com pertinência, Montaigne faz assentar essa "ordem" não em regras explícitas de condução do pensamento, mas na própria qualidade dos "esprits". A ordem dos "esprits" vêm se espelhar na ordem dos discursos que proferem, das conversas que entretêm, costuradas pelo fio do "à propos".

Se assim é, Montaigne está apto a dissociar o "verdadeiro" da "ordem" e "pertinência", o "falso" dos contrários deles: "Autant peut faire le sot celuy qui dict vray, que celuy qui dict faux: car nous sommes sur la maniere, non sur la matiere du dire" (id. ibid.). A conclusão formulada ambígua e intencionalmente pode tanto se aplicar com exclusividade ao capítulo estudado, que efetivamente trata da "maneira", como também referir-se obliquamente ao conjunto dos Ensaios, que efetivamente não tratam as matérias tentando estabelecer um saber seguro e certo sobre elas, permanecendo intencionalmente num registro opinativo, mas somente as trata no intuito de

d.C., as chamadas artes dictaminis, mais preocupadas com a composição de "cartas" e com o estilo adequado a cada uma das espécies que distingue. $\mathrm{O}$ tratamento dado por Montaigne ao tema parece ser, antes, o desenvolvimento e exploração de indicações vindas dos antigos, tais como as que encontramos na breve nota que Cícero dedica ao tema da "arte da conversação" naquela obra (Cf. CIC. De officiis I 132-36). 
exibir e ostentar a "maneira" do Ensaísta manejá-las e desenvolvê-las em seus exercícios de juízo, como tão bem nos instrui o "exódio" do capítulo II x, Des livres:

"[A] Je ne fay point de doute qu'il ne m'advienne souvent de parler de choses qui sont mieus traictées chez les maistres du mestier, et plus veritablement. C'est icy purement l'essay de mes facultez naturelles, et nullement des acquises; et qui me surprendra d'ignorance, il ne fera rien contre moy, car à peine respondroy-je à autruy de mes discours, qui ne m'en responds point à moy; ny n'en suis satisfaict. Qui sera en cherche de science, si la pesche où elle se loge: il n'est rien dequoy je face moins de profession. Ce sont icy mes fantasies, par lesquelles je ne tasche point à donner à connoistre les choses, mais moy: elles me seront à l'adventure connuez un jour, ou l'ont autresfois esté, selon que la fortune m'a peu porter sur les lieux où elles estoient esclaircies. Mais [C] il ne m'en souvient plus. Et si je suis homme de quelque leçon, je suis homme de nulle retention. [A] Ainsi je ne pleuvy aucune certitude, si ce n'est de faire connoistre jusques à quel poinct monte, pour cette heure, la connoissance que j'en ay. Qu'on ne s'attende pas aux matieres, mais à la façon que j'y donne." (II X, p. 407-8)

Muito a propósito, voltando ao nosso De l'art de conferer, Montaigne nos fala de uma atitude de leitura e de comunicação, bastante consentânea com seu projeto de escrever um livro que ensine antes a manière de seu autor que um saber sobre as matières que ele possa trazer, já que ao ler procura menos a "ciência" e "assunto", e mais a "façon" do autor, ou ao conversar com algum espírito famoso de seu tempo, menos "ensino", e mais "conhecimento", com o convívio, da pessoa que freqüenta:

"[C] Et tous les jours m'amuse à lire en des autheurs, sans soin de leur science, y cherchant leur façon, non leur subject. Tout ainsi que je poursuy la communication de quelque esprit fameux, non pour qu'il m'enseigne, mais pour que je le cognoisse." (III VIII, p. 928, grifo meu)

Embora num passo imediatamente anterior afirme ter um humor que se conforma ao preceito de Alcibíades, olhando tanto a forma quanto a substância, tanto o advogado quanto a causa, não há como deixar de aceitar que o plano da "maneira" assume uma importância e relevância muito acentuadas, quando a questão da verdade sobre as matérias fica afastada pela 
ausência de critérios que selecionem os discursos verdadeiros dos falsos. Se o lógos não se conforma às coisas, se sua relação com elas permanece problemática, a tarefa passa a ser a da conformação e ordenação do próprio lógos, na busca que por meio dele se efetua. Por isso não espanta que, em seguida, Montaigne associe "o ato de dizer a verdade" a qualquer um, enquanto reserva a bem poucos as "qualidades" ou "modos" que distinguem o mero dizer, do dizer bem e com pertinência: "[B] Tout homme peut dire veritablement; mais dire ordonnéement, prudemment et suffisamment, peu d'hommes le peuvent" (id. ibid.). Os verdadeiros traços distintivos do "espírito" estão nestes três "modos", chamemo-los assim, do dizer. Não cumprir as suas altas exigências é sinal de inépcia. Aliás, da "ignorância", diz-nos Montaigne, podemos esperar, seja a "falsidade", seja a "inépcia": "Par ainsi, la fauceté qui vient d'ignorance ne m'offence point, c'est l'ineptie" (id. ibid.). È com a segunda que se irrita nosso autor, surpreendentemente. Não o afeta a "falsidade" oriunda dela, porque todos, se não de fato, ao menos de direito deveriam confessar sua hesitação e dúvida a respeito da verdade das próprias opiniões, a possível falsidade delas. Os dogmáticos, de fato, acreditam estar na posse da verdade. Montaigne posiciona-se, ao menos neste texto, como alguém que ignora e está em busca ainda; não há que negar esta profissão de fé na zétesis. E reorienta-se para a "maneira" em busca de outros critérios que separem os homens segundo seu valor e mérito. O primeiro deles já posto é o da ordem na conduta do debate, na condução da busca, ordem do pensamento, ordenação das idéias. A ignorância, no entanto, que convive com a ordenação e não engendra inépcia, sabemos como Montaigne a descreve no último dos capítulos dos Ensaios, e a associa ao preceito délfico do conhecimento de si mesmo, bem como ao paradoxo do "princípio do conhecimento":

"[B] [...] L'advertissement à chacun de se cognoistre doibt estre d'un important effect, puisque ce Dieu de science et de lumiere le fit planter au front de son temple, comme comprenant tout ce qu'il avoit à nous conseiller. Platon dict aussi que prudence n'est autre chose que l'execution de cette ordonnance, et Socrates le verifie par le menu en Xenophon. Les difficultez et l'obscurité ne s'aperçoivent en chacune science que par ceux qui y ont entrée. Car encore faut il quelque degré d'intelligence à pouvoir remarquer qu'on ignore, et faut pousser à 
une porte pour sçavoir qu'elle nous est close. [C] D'où naist cette Platonique subtilité que, ny ceux qui sçavent n'ont à s'enquerir, d'autant qu'ils sçavent, ny ceux qui ne sçavent, d'autant que pour s'enquerir il faut sçavoir de quoy on s'enquiert. [B] Ainsin en cette-cy de se cognoistre soy mesme, ce que chacun se voit si resolu et satisfaict, ce que chacun y pense estre suffisamment entendu, signifie que chacun n'y entend rien du tout, [C] comme Socrates apprend à Euthydeme en Xenophon." (III XIII, p. 1075)

Pois bem, este "saber empurrar a porta", ainda que seja para reconhecer que ela nos está fechada, "saber" que exige "algum grau de inteligência" e que só é percebido por aqueles que em certa medida adentraram em cada ciência, não é à-toa que o encontramos associado a uma "ignorância" que em nada se aproxima daquela que produz a inépcia. É esta ignorância mais refinada, consciente de si, que desde o início vimos associada à aptidão para entrar no debate contraditório, ao contrário dos "opiniastres" que, em sua cólera, mostram-se ineptos para este exercício. Esta ignorância está, pois, excluída dos atributos associados a eles, que são essencialmente dogmáticos, bem como dos que qualificam o "tolo", se é que estas figuras são facilmente discerníveis aqui. Mostramos como, tanto o pedantismo dos que não digeriram bem suas lições e tem uma relação servil com as letras, quanto o dogmatismo das escolas, dão às mãos quando se trata de comportamentos tolos.

No término deste movimento de exposição da "ordem", Montaigne atinge o ápice de sua irritação com a forma errada do "tolo", o que dará ensejo à abertura do próximo movimento, em que se mesclam a auto-acusação - que a assim por ele chamada jurisdiction interne faz dele mesmo -, com o segundo "preceito", concernente à prudência do dizer. Examinemo-lo antes de encerrar este capítulo.

"[B] J'ay rompu plusieurs marchez qui m'estoyent utiles, par l'impertinence de la contestation de ceux avec qui je marchandois. Je ne m'esmeus pas une fois l'an des fautes de ceux sur lesquels j'ay puissance; mais, sur le poinct de la bestise et opiniastreté de leurs allegations, excuses et defences asnieres et brutales, nous sommes tous les jours à nous en prendre à la gorge. Ils n'entendent ny ce qui se dict ny pourquoy, et respondent de mesme; c'est pour desesperer. Je ne sens heurter rudement ma teste que par une autre teste, et entre plustost en composition 
avec le vice de mes gens qu'avec leur temerité, importunité, et leur sottise. Qu'ils facent moins, pourveu qu'ils soyent capables de faire: vous vivez en esperance d'eschauffer leur volonté; mais d'une souche il n'y a ny qu'esperer ny que jouyr qui vaille." (III VIII, p. 928)

A afirmação primeira, além de nos ensinar quão vasto é mesmo o espectro de relações que Montaigne inclui sob a sua conference, já que aqui ele fala de uma negociação privada e econômica ("marchez", "marchandois"), encarece e eleva seu apego pela "ordem", pois a "impertinência da contestação" faz que ele deixe de lado até mesmo a "utilidade", diga-se o benefício ou lucro, que the traria o negócio. Em seguida, acrescenta que os pequenos erros ou descuidos cometidos ("fautes") pelas pessoas sob as quais tem poder (ou seja, seus familiares e serviçais) nem uma vez por ano o "comovem" - ainda o páthos colérico - como o fazem os "vícios" implicados em suas alegações, escusas e defesas - qualificadas de "asnieres et brutales" -, ou seja, a "cólera" é suscitada pela maneira errada de eles se desculparem, pela "bestise et opiniastreté" das respostas, o que acaba por arrastá-los cotidianamente as vias de fato ("nous sommes tous les jours à nous en prendre à la gorge"). A dificuldade que Montaigne acentua aqui, e que surge do encontro com esta outra "cabeça" ("teste"), deriva menos de uma primeira ação, ela também viciosa, mas com a qual diz "entrar em composição", do que desta segunda, irritante para ele em sua "temeridade, importunidade e tolice". O comportamento tolo diz respeito à ação viciosa presente nas alegações, nas desculpas, nas tentativas infundadas de justificar a primeira ação, cujo vício mesmo não irrita. Não são opiniões contrárias sobre o "caso" que se opõem, mas maneiras diversas que entram em choque, e desordenam a conversa. Pode-se dizer que, segundo Montaigne, as respostas pecam por dois aspectos, aqui quase indiscerníveis: por um lado, vemos que há falta de entendimento (eles não entendem nem o que se diz, nem porque se diz algo), isto é, reconhecemos na "tolice" um matiz de defeito intelectual, devido à sua incompreensão; por outro, vemos que há certa "teimosia" em seu comportamento, ou seja, eles respondem mesmo sem entender, até porque se recusam a entender e discutir, e esta má vontade denota já um traço de caráter, um defeito moral. Montaigne e os seus se agarram pelo pescoço, ao 
que sugere a passagem, seja porque o erro cometido, diante de uma eventual repreensão, deveria ser admitido sem tentativa de desculpa, já que patente, seja porque deveria ser defendido por argumentos e motivos outros que os alegados, mais pertinentes e adequados ao "caso". O que reclama na tolice destes serviçais e cobra deles é que, ao responder, que respondam "à propos", e isto exige, por um lado, que se compreenda "o que" se diz, e "porque" se diz algo, ou seja, que se dê atenção ao outro; por outro, que não se responda com imprudência e sem "senso" do que é oportuno dizer, no "caso", dizendo qualquer coisa só para se livrar da repreensão, sem grande preocupação com a pertinência do que alega. Se a tolice é temerária, é porque imprudentemente tenta responder pelo que esta acima de sua capacidade; se é importuna, é porque, ao fazê-lo, erra e responde de modo inadequado. O que a tolice impede aqui é que uma verdadeira relação de comunicação se estabeleça, e ela só se estabelece quando os interlocutores falam uns aos outros da mesma coisa. O vício acusado na tolice, portanto, diz respeito a uma incapacidade de se ajustar ao interlocutor, atentando ao que ele diz, e, daí, responder sem desviar-se da matéria. No fundo, a própria incompreensão deriva, em última análise, não somente de uma incapacidade natural ou produzida pela indigestão intelectual de que tratamos, mas - e esta a acusação mais profunda do Ensaísta neste passo - da própria falta de vontade de esforçarem-se para ordenar o pensamento. Por isso arremata considerando já que deveriam assumir fazer somente aquilo pelo que seriam capazes de responder. Por fim, o desprezo de Montaigne pelos tolos chega a igualá-los, na impossibilidade de "aquecer-Ihes a vontade", ou seja, engajá-los num esforço de ordenação, a um "cepo", matéria inerte de que não há nada para esperar e fruir.

Vimos, portanto, como da acusação de uma falta de "ordem" na tolice, que Montaigne claramente associa a uma formação intelectual e moral que se desvia de suas primeiras e principais tarefas, formar o juízo e os costumes, para cuidados com a memória e os artifícios, passou, neste último movimento, a posição dos três "modos" ou "qualidades" do dizer, já tendo tratado o primeiro deles, que é propriamente a "ordem", que fez assentar nas operações do são entendimento e suas alegações, qualificadas pelo "à propos". E o último movimento analisado adentra já, em grande medida, o domínio da "prudência" e da "suffisance", outros dois modos do dizer, já que 
víamos despontar ali uma temeridade e uma incapacidade no tolo, de que Montaigne cuidará de nos advertir em seguida.

\subsection{O dire prudemment e a jurisdiction interne}

Ao longo de todo o desenvolvimento precedente Montaigne semeou sua "impaciência" diante da tolice, sendo que a manifestação mais aguda de sua "cólera" ocorre no passo imediatamente anterior a esta interpelação repentina de um "outro", ou de sua própria consciência, de sua jurisdiction interne. No que segue ele fará o que nos prometera desde o início: assumirá abertamente e acusará como vício sua impaciência, acolhendo a reprovação e valendo-se deste tour d'esgrime, de que sai ele próprio ferido, para encaminhar a discussão da segunda condição da excelência do "dizer": o "dire prudemment". A prudência, como se verá, além da advertência sobre as intervenções temerárias - porque impulsivas e defensivas - e importunas do tolo a que já se referiu na passagem imediatamente anterior, adverte acima de tudo sobre o risco de voltarem-se nossas armas contra nós em matérias controversas, o que é justamente o objetivo daquele que pergunta no embate dialético (levar o respondedor a se contradizer). Avisado deste perigo, Montaigne recolocará a necessidade de correção mútua, calcando-se no lugarcomum de que não vemos nossos próprios erros. Vejamos em que termos.

"Or quoi, si je prens les choses autrement qu'elles ne sont?" (id. ibid., p. 928). Montaigne assume, diante da repreensão e acusação, que pode sim "estar tomando as coisas diferentemente do que são". Ele não nega este ponto, nem tampouco apresenta propriamente alegações em sua defesa. Faz-se acusador, não defensor. Mas a auto-acusação não deixa de ter suas sutilezas [e obliqüidades, que acabam por justificar sua atitude]. Vejamos:

"Il peut estre; et pourtant j'accuse mon impatience, et tiens premierement qu'elle est également vitieuse en celuy qui a droict comme en celuy qui a tort: car c'est tousjours un'aigreur tyrannique de ne pouvoir souffrir une forme diverse à la sienne" (id. ibid., p. 928-9).

A primeira alegação assinala o caráter vicioso tanto "naquele que está certo" ("en celuy qui a droict") e "naquele que está errado" ("en celuy qui a 
tort"). A "impaciência" admitida, entenda-se, é igualmente viciosa nele, que está certo em exigir a "ordem" e o "à propos" na conversa, como o seria em alguém tumultuoso e sem conduta regrada, ou como no opiniastre. Em todo caso, sempre se trata de um "azedume tirânico" ("aigreur tyrannique") não poder suportar ("souffrir") uma "forma diversa da sua". Já pela "tirania" que qualifica o afeto que surge diante da "forma diversa" percebemos que o que está em jogo é o domínio de si, o controle das faculdades racionais do agente diante do que o contraria no plano da forma, ainda que tenha razão em exigir a ordenação. Ele perde o domínio racional sobre si quando cede ao páthos colérico e reage à "forma de espírito" que crê não se coadunar com a forma correta, porque não regrada pela ordenação imposta pelo "à propos". Vimos como Montaigne se dizia e se descrevia como capaz de sofrer "opiniões diversas" das suas, no limite, contraditórias às suas. Vemos agora como acusa, de acordo com o que prometera, sua incapacidade de sofrer uma "forma diversa" e como isso the rouba o domínio. Não poder sofrer uma forma diversa acaba por se traduzir numa paixão que o "deforma", pois destempera e desajusta a sua "façon" de disputar. Não mais se acomoda às regras que ele mesmo põe. Ora, mas por que essa incapacidade? A pressuposição dogmática de razão que impedia o opiniastre tanto de sofrer a contradição como de ver recusada sua repreensão parece afetar Montaigne no que diz respeito à "forma". Seria ele um opiniastre da forma?

A segunda alegação aprofunda o problema e nos dá elementos para tentar responder: "et puis, qu'il n'est, à la verité, point de plus grande fadese, et plus constante, que de s'esmouvoir et piquer des fadeses du monde, ny plus heteroclite. Car elle nous formalise principallement contre nous" (id. ibid., p. 928-9). Variando o vocábulo para marcar-lhe o traço específico, vemos assomar uma nova "tolice" ("fadese"), a maior, a mais constante, a mais heteróclita. Precisamente, a "tolice" extravagante que há em "se deixar comover e irritar" com as "tolices do mundo". A exasperação, porém, só assume esse caráter superlativo porque resulta não somente do espetáculo das tolices exteriores ao sujeito e que ele encontra nos outros, mas "principalmente" do reconhecimento de que estas mesmas tolices se encontram nele. Trazendo à consideração, imediatamente, Heráclito e Demócrito - este último, é certo, na figura do sábio Misão, que compõe com o 
primeiro, não nomeado, este par mítico e inseparável que representa as duas posturas extremas diante da condição humana, o riso e o choro -, Montaigne corrobora e reforça a idéia de que os motivos para a irritação já se encontram inscritos em nós, bastando voltarmo-nos para dentro de nós, a fim de assim constatar:

"[B] [...] et ce philosophe du temps passé n'eust jamais eu faute d'occasion à ses pleurs, tant qu'il se fut considéré. [C] Mison, I'un des sept sages, d'une humeur Timoniene et Democritiene, interrogé dequoy il rioit tout seul: De ce mesmes que je ris tout seul, respondit-il." (id. ibid., p. 929)

Não é preciso buscar fora motivos para lágrima ou riso. É digno de nota que ocorra ao nosso autor assumir aqui a perspectiva da imperfeição da condição humana, que suscita estas duas respostas contrárias: a que lamenta a condição mortal e imperfeita do homem, ainda muito "filantrópica" aos olhos de Montaigne; a que escarnece e zomba dele, e, portanto, é mais ajustada aos seus méritos em sua "misantropia", segundo o juízo dele ainda ${ }^{44}$. Basta olhar para dentro e inspecionar-se para ver quantas tolices dizemos, segundo nosso modo de ver; logo, quão mais freqüentes, segundo o modo dos outros nos ver e julgar: "Combien de sottises dis-je et respons-je tous les jours, selon moy; et volontiers donq combien plus frequentes, selon autruy! [C] Si je m'en mors les levres, qu'en doivent faire les autres?" (id. ibid.). E conclui constatando a inelutável obrigação de viver entre os vivos, se não de modo a não se preocupar e querer corrigir todos os erros que encontra, ao menos de modo a não se alterar com isso: "[C] [...] Somme, il faut vivre entre les vivants, et laisser courre la riviere sous le pont sans nostre soing, ou, à tout le moins, sans nostre alteration" (id. ibid.).

Mas, o Ensaísta não se contenta e insiste ainda nas razões desta impossibilidade de "sofrer este encontro" sem alteração: "Voyre mais, pourquoy, sans nous esmouvoir, rencontrons nous quelqu'un qui ayt le corps tortu et mal basty, et ne pouvons souffrir le rencontre d'un esprit mal rengé sans nous mettre en cholere?" (id. ibid.). Do "corpo defeituoso", diga-se somente que sua forma não depende em nada da vontade e do empenho daquele que o

\footnotetext{
${ }^{44}$ A respeito destas duas posturas sobre a condição humana que Montaigne retoma amiúde, v. I L, De Democritus et Heraclitus.
} 
possui, sendo um quinhão natural em grande medida não passível de reforma. Ao contrário, a forma do "espírito mal arranjado" de certo modo está, ou ao menos esteve, em poder daquele a quem incumbe fazer a ordenação, ou seja, o próprio espírito. E vimos como o processo de formação que se desviava para os cuidados inessenciais do artifício deformava os espíritos e era apontado como principal causa de sua tolice. Se ele carece de forma e ordenação isto deve ser imputado a ele próprio, que não demonstrou nem dispensou o zelo necessário para tal. Espera-se diligente esforço e não desleixo. Montaigne, contudo, só não nos surpreende com a resposta que dá aqui a pergunta que formula ${ }^{45}$, porque ela se alinha ao que já havia dito antes:

"Cette vitieuse aspreté tient plus au juge qu'à la faute. Ayons tousjours en la bouche ce mot de Platon [C]: Ce que je treuve mal sain, n'est-ce pas pour estre moy mesmes mal sain? [B] Ne suis-je pas moy mesmes en coulpe? mon advertissement se peut-il pas renverser contre moy? Sage et divin refrein, qui fouete la plus universelle et commune erreur des hommes. [...] Ce fut ingenieusement bien dict et tres à propos par celuy que l'inventa:

Stercus cuique suum bene olet.

[C] Noz yeux ne voient rien en derriere." (id. ibid., p. 929)

Mais uma vez, o movimento é de reflexão e volta para si, o que se imputa não é falta de diligência e zelo no que comete o erro, cuja gravidade, aliás, nem sequer se discute, mas a "viciosa aspereza" do juiz. É o juiz que, em seu rigor, acaba por distorcer a falta, em vez de relevá-la, "deixando o rio correr sob a ponte, sem preocupar-se com isso". Distorção decorrente em grande medida do próprio páthos, que lhe altera o juízo. É ele que - conforme ao "sábio e divino refrão" que lembra "o mais universal e comum erro dos homens": sua cegueira para os próprios erros e vícios - deve se perguntar se "o que acha malsão, não é por ele mesmo ser malsão", se ele mesmo "não se

\footnotetext{
${ }^{45}$ Só muito mais adiante, nos fornecerá uma outra resposta bem menos oblíqua para sua irritação diante de um "esprit mal rengé", quando encerrar o movimento em que ensina a desmascarar as suffisances estrangeres. Por enquanto, a acusação de irritação é imputada ao juiz. Veremos que depois a irritação encontra suas razões também na ignorância segura do réu (Cf. infra, p....)
} 
encontra em culpa". E desenvolve ainda este motivo da cegueira, na continuidade do acréscimo posterior a 1588, nos seguintes termos:

"[C] [...] Cent fois du jour, nous nous moquons de nous sur le subject de nostre voisin et detestons en d'autres les defauts qui sont en nous plus clairement, et les admirons d'une merveilleuse impudence et inadvertance. Encore hier je fus à mesmes de veoir un homme d'entendement et gentil personnage se moquant aussi plaisamment que justement de l'inepte façon d'un autre qui rompt la teste à tout le monde de ses genealogies et alliances plus de moitié fauces (ceux-là se jettent plus volontiers sur tels sots propos qui ont leurs qualitez plus doubteuses et moins seures); et luy, s'il eust reculé sur soy, se fut trouvé non guere moins intemperant et ennuyeus à semer et faire valoir les prerogatives de la race de sa femme. $O$ importune presumption de laquelle la femme se voit armée par les mains de son mary mesme!" (id. ibid., p. 929-30)

Destaquemos somente que o erro tão freqüente apontado aqui decorre não da impossibilidade, mas da falta de hábito de voltar-se para si ("reculer sur soy"), decorre da "impudência e inadvertência" em se admirar nos outros erros que mais claramente estão em si. E num cantinho de página Montaigne nos remete mais uma vez ao tema da presunção.

Deixamos, porém, de comentar um acréscimo inserido logo após a resposta dada à pergunta sobre a impossibilidade de encontrar um "esprit mal rengé" sem deixar-se tomar pela cólera, pois toca diretamente no problema da prudência na conversação. No texto citado mais acima, Montaigne já se perguntava sobre a possibilidade da "advertência se voltar contra aquele que adverte". Relendo seu escrito, aproveita o ensejo da advertência que sua consciência acaba de fazer contra ele em benefício de sua discussão dos "modos" do dizer e acrescenta:

"[C] Non seulement les reproches que nous faisons les uns aux autres, mais nos raisons aussi et nos arguments es matieres controverses sont ordinerement contournables vers nous, et nous enferrons de nos armes. Dequoy l'ancienneté m'a laissé assez de graves exemples." (id. ibid.)

Na conference, a prudência demanda e exige que se esteja sempre atento para o fato de que, em se tratando de matérias controversas - e vimos 
que, por princípio as matérias todas são passíveis de discussão -, os mesmos argumentos empregados podem se voltar contra nós e nos ferir. Isto é, a prudência no debate seleciona com critério e cautela as "armas" que emprega, e avisa que seu manejo pede cuidado. Esta potência de perceber e prever quais argumentos devem ser empregados e quais não, pois nos abrem o flanco para uma "revirade", obviamente se alimenta da força das concepções e da ordenação da "teste bien faicte". Pois, somente ela é capaz de perceber o que se arrisca numa pergunta ou numa resposta. O peso de uma objeção, ou de assumir uma determinada premissa. As conseqüências decorrentes de se assumirem certas posições. Montaigne voltará a isso quando arrolar as advertências contra as suffisances estrangeres. E vemos ainda que Montaigne exemplifica no próprio desenvolvimento de sua discussão no capítulo, o risco a que chama a atenção esta advertência de prudência, pois sua alteração diante do tolo o leva tanto a expor as regras da boa conversa, como a se expor ao contra-golpe de que ele mesmo nem sempre é apto para o seu exercício.

Porém, se os erros estão em nós também, se podemos nos ferir com as armas empregadas para golpear, isto não arriscaria o próprio exercício da conference, na medida em que a prudência pediria antes que se guardasse o silêncio, toda vez que, culpados da mesma falta, uma repreensão pudesse nos expor a um contra-golpe?

A resposta é não só clara como ousada no contexto cristão em que escreve:

"[C] Je n'entens pas que nul n'accuse qui ne soit net, car nul n'accuseroit; voire ny net en mesme sorte de coulpe. Mais j'entens que nostre jugement, chargeant sur un autre duquel pour lors il est question, ne nous espargne pas d'une interne jurisdiction. C'est office de charité que qui ne peut oster un vice en soy cherche à l'oster ce neantmoins en autruy, où il peut avoir moins maligne et revesche semence. Ny ne me semble responce à propos à celuy qui m'advertit de ma faute, dire qu'elle est aussi en luy. Quoy pour cela? Tousjours l'advertissement est vray et utile. Si nous avions bon nez, nostre ordure nous devroit plus puïr d'autant qu'elle est nostre." (id. ibid., p. 930)

Repõe-se assim a disciplina verdadeira e útil de entre-acusação e correção como "ofício de caridade", mesmo para aqueles que têm a mesma 
culpa. Dada a perspectiva da "imperfeição", ou deveríamos dizer mesmo "finitude" humana, e a dificuldade para nós de ver os próprios erros, o combate desta "imperfeição" por meio da conversa em que se busca estirpar ("oster") o vício menos plantado e arraigado em outros, assume toda importância e mostra sua "envergadura". Não se tratando de uma comunidade perfeita de homens, o que lhes resta é buscar, por meio da exposição ao olhar e a palavra dos outros, atingir o máximo de perfeição possível para eles. Somente, a disciplina agora conta com a advertência prudente do risco em empunhar e manejar armas que podem nos ferir, advertência da consciência em sua interne jurisdiction.

Resta uma última consideração sobre este movimento. Se é da tolice e desordenação que deriva sua "aspreté" ao julgar, se o problema já está no juiz, uma outra dificuldade se nos depara então. Que sentido poderia haver em continuar se alterando com a "forme diverse" se a tolice está nele também? Ela não seria exatamente uma "forme diverse". É certo que ao exibir seu erro Montaigne perfaz seu útil projeto de corrigir os outros ao se enforcar diante de seus leitores. Contudo, a disciplina par contrarieté a que seu humor se presta, não deveria fazer igualmente que se corrigisse diante da "forma" errada do tolo? Ela não é de evitar como o são todos os comportamentos tolos que arrolou já no exórdio, e com os quais dizia se instruir melhor do que com os exemplos de boa conduta? O que há na forma errada do tolo para que não a tome como contra-exemplo e se corrija? Pois devemos reconhecer que não é exatamente isso que faz quando, interpelado pela própria consciência, reconhece a própria tolice e a necessidade de viver entre os vivos sem alteração. Poderíamos pensar que Montaigne não se corrige, pois, como alegara desde a abertura do capítulo seu erro é "quase natural e incorrigível" e ele o instrumentaliza no intuito de advertir e corrigir o mesmo erro nos outros.

Mas pode-se aduzir ainda que não pode nem alegar a força daqueles que nunca se exasperam, diante de quem quer que seja, nem assumir a mesma fraqueza do tolo. Sua atitude é ambígua, visto que se situa numa espécie de "situação média" entre a tolice e a ordenação dos espíritos vigorosos e regrados, que o distingue dos dois. Não há completo controle para ele, que se ordena diante da ordem, mas descamba para o vício diante da desordem; para ele, que possui a reta intenção de conduzir com ordem o debate, mas não a traduz em ato quando seu interlocutor não possui a mesma 
capacidade. Montaigne se excede no impulso que o faz evitar e se afastar da forma errada do tolo. Na conversa ideal o erro de que se afasta não está no outro, mas nele mesmo, e só é visto porque o outro, em suas repreensões e objeções conformes às regras da manière, devolve como num espelho a imagem dele refletida, dando-Ihe a oportunidade de reconhecer-se e corrigir-se às suas próprias expensas. Na conversa com o tolo este processo de correção fica comprometido e impedido, por causa da falta de "ordem". Como a trama ordenada da conversa se tece a dois, Montaigne se vê impedido de conduzi-la ao seu fim, e desvia para a discussão dos meios. Porém, seu desvio é, por assim dizer, "intemperante": ele incorre em uma hýbris, e não se contém em seu impulso de corrigir. Se o tolo peca por falta de ordenação em sua ação, Montaigne peca por excesso de desejo de ordenação. Mas por desejar ele já mostra que carece. Carência que não está exatamente só nele, mas que resulta do encontro, que depende da relação. E na conference não se realiza nada sozinho, já que não se trata de um "ato para um só personagem", já que ela se tece e urde da relação bem sucedida dos dois que se entretêm, já que, enfim, da perspectiva da condição imperfeita dos homens (dos vivos) o esforço de ordenação é incumbência de todos e depende da dupla felicidade do bom nascimento e da boa formação (institution). Portanto, a correção a que se limita aqui é somente a do "julgamento" isento sobre si mesmo que opera sua própria consciência. "Julgamento" levado a cabo pelo tribunal da interne jurisdiction. Este descolamento do "juízo" em relação aos próprios erros, morais ou intelectuais, é testemunhado nos Ensaios em várias passagens. Testemunha-o um passo do ensaio de fechamento do livro em que assim se exprime:

"[B] [...] Le jugement tient chez moy un siege magistral, au moins il s'en efforce soingneusement; il laisse mes appetis aller leur trein, et la haine et l'amitié, voire et celle que je me porte à moy-mesme, sans s'en alterer et corrompre. S'il ne peut reformer les autres parties selon soy, au moins ne se laisse il pas difformer à elles: il faict son jeu à part." (III XIII, De l'experience, p. 1074)

Com isso, esclarecemo-nos de que a disciplina par contrarieté a que seu humor se presta de certo modo é respeitada, duplamente. Pois, a trama sutil do arrazoado nos pôs na seguinte situação: ele não só instruiu e advertiu 
neste movimento os outros para o erro que comete, como foi capaz de exporse a correção do tribunal da "jurisdição interna", mantendo íntegro seu "jugement", contra a presunção de superioridade. Não se trata de um reconhecimento da mesma fraqueza do tolo, nem tampouco de uma reforma em que recobrasse a capacidade de conversar com o tolo sem alteração, mas de uma mudança de estratégia. Passa agora, se não a conversar no sentido mais elevado, ao menos a avaliar sua força, ou melhor, a acomodação da força à carga assumida, na discussão que segue da suffisance. 


\section{Capítulo 2 - O DIRE SUfFISAMment}

Em uma das últimas advertências que dá em seu De l'institution des enfans a respeito da "eschole du commerce des hommes" na formação da criança, Montaigne preceitua que, em companhia, os olhos se acostumem a desviar-se dos "primeiros assentos" e percorram os convivas em busca de pessoas de maior "suffisance", porque comumente os cargos e as dignidades são ocupados por "homens menos capazes" e porque não se confundem "grandeza de fortuna" e "suffisance" (Cf. I XXVI, p. 155: "[A] On l'advertira, estant en compaignie, d'avoir les yeux par tout; car je trouve que les premiers sieges sont communément saisis par les hommes moins capables, et que les grandeurs de fortune ne se trouvent guieres meslées à la suffisance"). E algumas linhas adiante:

"Il sondera la portée d'un checun: un bouvier, un masson, un passant; il faut tout mettre en besongne, et emprunter chacun selon sa marchandise, car tout sert en mesnage; la sottise mesmes et foiblesse d'autruy luy sera instruction. A contreroller les graces et façons d'un chacun, il s'engendrera envie des bonnes, et mespris des mauvaises." (id. ibid., p.155-6)

Já, portanto, em seu primeiro livro, o Ensaísta tirava partido das tolices do mundo em proveito da educação de seu "enfan de maison", ao exigir do preceptor que o fizesse sondar a "estatura" de cada um, levar tudo em conta, arrolar as "graças e modos", a fim de engendrar desejo dos bons modos, desprezo dos maus. Como se vê, o mesmo esquema que preside a disciplina par contrarieté consta das advertências formadoras do juízo.

Este aviso nos fornece uma boa entrada para o que segue em nosso De l'art de conferer. Porquanto, no regime da conference, que não exatamente coincide com o da institution no seu emprego da freqüentação mundana, passa-se agora ao que poderíamos chamar de meios para uma "avaliação" do "porte" dos "esprits" com que se encontra em companhia. A atenção à "sottise" e "foiblesse" serve aí para sondar e selecionar criteriosamente qualidades intelectuais, para penetrar tão mais profundamente nos "esprits" quanto é possível a partir de suas manifestações: gestos, ações, discursos. Num 
primeiro momento, atento mais a exterioridade da "contenance", Montaigne ensina-nos a dissociar "grandeza de fortuna" e "suffisance", que acaba se revelando apenas "d’apparence"; num segundo, contando já com as exteriorizações por palavras do "valor" que se tenta discernir, ensina a sondar e reconhecer as "suffisances" de empréstimo, que se denunciam como "estrangeres".

\subsection{Suffisances d'apparences}

Montaigne avança, após a reposição da disciplina de entre-correção e munido agora pela consciência da interne jurisdiction, notando que "les sens sont nos propres et premiers juges, qui n'apperçoivent les choses que par les accidens externes" (III VIII, p. 930). Vemos aqui que os homens julgam primeiro e mais propriamente com os sentidos e que nestes constata-se uma falha insuperável: a percepção sensível, a impressão que os sentidos nos transmitem das coisas, só nos apresenta seus acidentes externos, nada nos comunicando de seus atributos internos, de seu núcleo essencial. E se julgamos primeiro e propriamente - dada nossa condição "merveilleusement corporelle", como dirá logo adiante - com os sentidos, o que sabemos das coisas é apenas um "saber" do atributo exterior e acidental, aquilo que ela mesma não é essencialmente, atributo que pode perder, sem que deixe de ser o que é, não se podendo nem mesmo afirmar que há nela algo além desta acidentalidade, se não houver outro meio que os sentidos que nos instrua. Portanto, a informação que obtemos por via da experiência sensível não basta para afirmarmos algo seguro e estável acerca delas. Montaigne desconfiará dos sentidos, da experiência sensível e do conhecimento que ela nos transmite e corrigirá, ou melhor, pedirá que se corrija a distorção presente nos juízos formulados a partir deles. O modo de argumentação ${ }^{46}$ cético mais evidente em seu procedimento neste passo é o que se refere à variação das impressões sensíveis segundo às posições, às distâncias e os lugares, o que leva a não poder fundar nelas nenhuma certeza.

${ }^{46}$ Cf. Sex. Emp., HPI 14, 118-123. 
O que segue é uma colação, que já dispõe os elementos da dupla crítica que o autor moverá contra o que chama de as "duas tiranias": a efetiva e a "falante". Ele compara "les pieces du service de nostre societé" - as "polices" -, inseparáveis de seu "perpetuel et universel meslange de ceremonies et apparences superficielles", com a conference, na qual "la gravité, la robbe et la fortune" de quem fala dá crédito a afirmações vãs e ineptas. A "melhor e mais efetiva parte" das "polices", do conjunto de instituições e leis que regem a sociedade dos homens, consiste em "cerimônia e aparência". Elas são, em boa medida, uma espécie de espetáculo ilusório em que se encena uma grandeza e prestígio sem estofo e fundo, sem fundamento e sem mérito real daqueles que governam, mas que ainda assim sustentam o exercício do mando, e a obediência do súdito. E são assim exatamente porque "c'est tousjours à I'homme que nous avons affaire, duquel la condition est merveilleusement corporelle" (id. ibid.). A própria condição corporal, sensível, daquele com quem se lida impõe que haja "mistura de cerimônia e aparências superficiais" no governo das cidades, já que ele julga primeiro e propriamente com os sentidos e, conforme julga, dá crédito e obedece. A "mistura de cerimônia e aparência" é tanto "efetiva" como "melhor parte", porque as regras, as leis e as instituições, são necessárias aos homens, ainda que se sustentem somente por este prestígio vão, vazio, que não é mais do que o seu ajuste e acomodação àquele sobre o qual devem se impor e imperar. Mas, é vão aos olhos de quem julga não por meio dos mesmos sentidos, e reconhece a relatividade das instituições e leis - que se impõem, como formula alhures, "não porque são justas, mas porque são leis" -, ao mesmo tempo, que sua necessidade para o convívio dos homens. Na conversa igualmente a aparência confere "crédito" ao que, de fato, não tem, ao que é "vão e inepto", pura aparência de "suffisance". No entanto, a mesma necessidade de respeito e obediência infundidos pela "aparência" não se impõe no domínio "privado" da conference, e o traço desdenhoso e soberbo (“morguant") dos poderosos é desafiado. Montaigne argumenta:

“il n'est pas à presumer qu'un monsieur si suivy, si redouté, n'aye au dedans quelque suffisance autre que populaire, et qu'un homme à qui on donne tant de commissions et de charges, si desdaigneux et si morguant, ne soit plus habile que cet autre qui le salue de si loing et que personne n'employe. Non seulement les 
mots, mais aussi les grimaces de ces gens là se considerent et mettent en compte, chacun s'appliquant à y donner quelque belle et solide interpretation." (id. ibid., p. 930-31)

O que se presume é que os homens "seguidos e temidos", ou os que se empregam no exercício das "comissões e cargos", tenham dentro deles ("au dedans") alguma "suffisance" e "habilidade" que os outros, do povo, que o "saúdam de longe", e de quem ninguém se serve, não teriam. A pressuposição de que são dotados de uma "capacidade" superior, pelo simples fato de ocuparem uma posição de destaque na hierarquia social, tem por conseqüência que todos considerem e levem em conta às palavras e os gestos ("grimaces") e se apliquem em lhes dar "uma bela e sólida interpretação"47.

È fácil entrever nesta alusão à interpretação das "grimaces" uma ironia com o séquito dos admiradores e aduladores dos que ocupam as posições de mando. Cortejo de "reverência e aprovação" de que Montaigne se afasta, ao desafiar que se rebaixem a "conference commune": "S'ils se rabaissent à la conference commune et qu'on leur presente autre chose qu'aprobation et reverence, ils vous assomment de l'authorité de leur experience: ils ont ouy, ils ont veu, ils ont faict; vous estes accablé d'exemples" (id. ibid., p. 931). A atitude preconizada simplesmente subtrai a aprovação e o temor reverente inspirado pela posição superior - pelo poder de quem está investido em um cargo ou comissão e que os projeta acima dos outros. Com isso o que se obtém é a igualdade entre os interlocutores exigida pela conversa comum. A resposta destes "senhores" dá ensejo a que se toque num ponto crucial para o pensamento do filósofo bordelês: o que alegam em contrário é a "autoridade" assentada em certa "experiência", visto que reagem e se recusam a descer de suas posições e deixar suas prerrogativas. Eles "ouviram, viram, fizeram". O que avançam, contudo, são "exemples", e os tomam por fundamento de sua "autoridade". O termo refere aqui cada uma das experiências particulares enquanto tais, sem que se extraia delas algo além desta mera particularidade relatada. Pelo simples fato de terem sido

\footnotetext{
47 Montaigne retomará algumas páginas adiante ("Or j'estois sur ce point...) o fio desta discussão sobre a opinião que a posição social e a dignidade infunde em nós, arrematando as observações iniciadas agora. Neste ponto, todavia, o texto começa a enveredar para a discussão de um "procedimento": o ensaio da conference commune, e dará as razões de sua desconfiança diante dos "grandes", numa longa "digressão" sobre as tiranias.
} 
encarregados de muitos affaires, neles se acumulou um grande número de "casos" particulares, que compõem o inventário e repertório de exemplos que alegam. Enquanto permanecem em uma estreita e estrita particularidade não meditada, somente lembrada e narrada, é a própria "exemplaridade" destes "casos" que está em questão. A experiência apoiada na simples memória e relato do "exemplo", verá recusada a autoridade que ela mesma se arroga, migrando esta mesma autoridade para o portador de uma "experiência" com sentido mais substantivo. É o que nos apresenta a resposta de Montaigne:

"[B] [...] Je leur dirois volontiers que le fruict de l'experience d'un chirurgien n'est pas l'histoire de ses practiques, et se souvenir qu'il a guery quatre empestez et trois gouteux, s'il ne sçait de cet usage tirer dequoy former son jugement, et ne nous sçait faire sentir qu'il en soit devenu plus sage à l'usage de son art. [C] Comme, en un concert d'instruments, on n'oit pas un leut, une espinete et la flutte, on oyt une harmonie en globe, l'assemblage et le fruict de tout cet amas. [B] Si les voyages et les charges les ont amendez, c'est à la production de leur entendement de le faire paroistre. Ce n'est pas assez de compter les experiences, il les faut poiser et assortir; et les faut avoir digerées et alambiquées, pour en tirer les raisons et conclusions qu'elles portent." (id. ibid.)

O exemplo do "cirurgião" é significativo, pois nos remete a uma arte que não pode deixar de se apoiar amplamente na "experiência" em seus procedimentos: a medicina. O que Montaigne distingue aqui é a "história das práticas" (a lembrança de que curou quatro empestados e três gotosos) do verdadeiro "fruto da experiência", qual seja, saber tirar deste "uso", desta memória das práticas particulares, algo que forme o "julgamento", bem como saber fazer-nos perceber que se tornou mais sábio com a prática. Cada uma das práticas oferecem ao "cirurgião" a ocasião para que progressivamente o julgamento se forme e para que um saber assente em sua "alma", desde que não se limite a simplesmente registrá-las na memória, a conservar sua lembrança. Não basta contar experiências feitas, é preciso "pesá-las e classificá-las", "digeri-las e destilá-las", para extrair-lhes razões e conclusões. As experiências (viagens, cargos) são portadoras de razões e conclusões que a simples memória não atinge, e que permitem "emendar" os que as fizeram. Emenda que se exibe e mostra pela própria "produção do entendimento" deles. 
Pois, assim, com cada experiência se aprende algo que vai para além dela mesma. A experiência no sentido mais substantivo a que aludimos acima se constitui a partir do trabalho ativo e inteligente do sujeito da experiência sobre cada uma de suas "experiências", trabalho que digere e destila (mais uma vez a metáfora da digestão) as lições que cada situação vivida comporta. As produções do entendimento mudam e fazem transparecer este trabalho de formação do juízo que leva em conta as razões de cada caso vivenciado, as conclusões a que se pode chegar a partir deles. $O$ acréscimo com a imagem do concerto de instrumentos, insiste, opondo-se à idéia de somatória dos sons individuais de cada instrumento, na "harmonia em globo", "reunião e fruto de todo este feixe", ou seja, o resultado é uma "síntese" qualitativamente diversa dos elementos que entraram em composição. Que não se possa deter este processo na simples lembrança ("souvenir"), o texto citado por si só evidencia. Contudo, tampouco se poderia pensar aqui que se trata da constituição de uma ciência que se venha fixar na alma a partir da retenção do que cada caso concreto teria de semelhante. Montaigne não dá este passo, apoiando-se numa generalidade ou universalidade abstraída do caso, para constituir um saber ou conhecimento que ajudasse na orientação futura do juízo diante de casos semelhantes: uma generalidade como a das leis, boa e má ao mesmo tempo, pois, como auxiliares necessários diante da singularidade das ações que julga, todavia, substituem de modo imperfeito um saber infalível que pudesse deduzir do universal um particular. Saber de que, aliás, em Montaigne nem cabe falar, dada a forma como acentua a mobilidade e a ingerência da diferença em todos os eventos. O processo que forma o juízo aguça, antes, o senso do particular e singular, avançando na direção oposta de uma generalização abstrata. Formar o julgamento, faculdade crítica por excelência, significa refinar o senso e o discernimento, apoiando-se na "experiência" digerida de um passado que não se repete. $O$ juízo opera distinguo, dissociações semânticas. Mas também predica, acusa um atributo de um sujeito.

Como é característico do ensaio, Montaigne deixa aflorar ao sabor de uma associação, temas que não desenvolve senão depois, ou que nem chega a desenvolver. A consideração sobre o grande número de historiadores, que segue a observação sobre a experiência, é deste tipo. Emerge, de modo breve, obviamente a propósito do distinguo que acaba de operar entre "experiência 
como memória" e "experiência digerida e destilada" e em pouquíssimas linhas é abandonada. Retornará bem depois. Aqui ela se presta a pôr com toda clareza o problema mais geral de que cuida no momento. O que se visa é o reconhecimento das suffisances resultantes da experiência formadora do julgamento e do entendimento. Os historiadores numerosos, da espécie que lembra aqui, são portadores de uma suffisance tomada de empréstimo, estrangere, aparente - porque alheia, ainda o veremos - tal como a dos homens com "grandeza de fortuna", entretanto, não exibida na pompa, mas enfeixada nos livros, que compõem. Leiamos:

"[B] [...] II ne fut jamais tant d'historiens. Bon est il tousjours et utile de les ouyr, car ils nous fournissent tout plain de belles instructions et louables du magasin de leur memoire; grande partie, certes, au secours de la vie; mais nous ne cerchons pas cela pour cette heure, nous cerchons si ces recitateurs et recueilleurs sont louables eux mesme." (id. ibid.)

O que Montaigne discerne aqui são dois méritos e, portanto, dois louvores. O das obras destes historiadores e o dos próprios historiadores. É bom e útil ouvi-los, pois nos fornecem livros "plenos de belas e louváveis instruções", em grande parte para "auxílio" ("secours"), ou benefício, da vida. Só que - eis o que lhes rouba, a eles, historiadores, o louvor, mas não enquanto historiadores, mas enquanto homens - fornecem-nos do "estoque" ("magasin") de suas memórias. São homens de memória, estes "recitadores e recolhedores", simples faiseur de livres, mas em geral não "judiciosos", pois se atém à lembrança, não ao exercício do julgamento. Montaigne obliquamente os acusa de que eles não fazem a experiência, no sentido forte, dos examples que relatam. O mérito todo recai em seus trabalhos, não neles. Por isso o louvor não cabe a eles. $E$ a discussão toda se centra exatamente no reconhecimento do mérito dos homens, que a conference enseja medir. Trata-se de descobrir se cabe ou não louvá-los. 
"Je hay toute sorte de tyrannie, et la parliere, et l'effectuelle" (id. ibid.). Estes últimos textos que vínhamos comentando servem de introdução ao ataque direto que move agora contra as "duas tiranias", numa espécie de "escapadela", porém, não "fora de propósito", pois ela é que assiste o "procedimento" de rebaixar à conversa comum, e "conferir" a suffisance da alma que se tem diante de si. No cerne desta crítica ao exercício ilegítimo da autoridade, encontram-se duas razões fundamentais: 1) a consideração da "proporção" entre "carga" e "força"; 2) o longo arrazoado sustentando que a Fortuna não distribui os bens segundo os méritos e capacidades, mas de modo caprichoso e arbitrário, conforme a imagem da deusa herdada dos antigos. Por isso é necessário que o julgamento corrija o efeito de distorção da impressão meramente sensível, atacando a vaidade conseqüente da assunção sem mérito de alguns a posições de "grandeza extraordinária". Tanto dos que se arrogam alguma prerrogativa e competência para falar, quanto dos que têm poder para mandar: o poder assentado nos que supostamente detém saber e o poder efetivo dos que ocupam as posições de mando. Com isso, Montaigne nos descreve, em função da igualdade de relação exigida pela conversa, um quadro nada perfeito e justo das hierarquias de saber e poder. Um quadro em que as diferenças e desigualdades não estão fundadas em nenhuma superioridade real, mas na distribuição do acaso e da sorte, e em que as "forças" muita vez ficam aquém do "peso" assumido e que se deve sustentar. Encontramos uma situação de fato em que toda distribuição de bens, riquezas, posições de mando, não assinala qualquer excelência e autoridade real, e em que os homens demonstram o quanto o "fardo" assumido ultrapassa o vigor e poder do "carregador", esmagando-os. No caso das "ciências", com clara reprovação dos "sçavantes" e de sua inépcia; enquanto no "governo" das coisas, dada a dificuldade implicada na idéia de um governo ideal e da virtus do princípe demandada para uma forma perfeita de "police", com um olhar mais complacente $^{48}$. Sigamos mais uma vez o passo ondulante do Ensaísta:

\footnotetext{
${ }^{48}$ Lembremos que em Montaigne as observações sobre a imperfeição dos regimes e formas de associação entre os homens nunca implica em recusar a obediência aos costumes e instituições, já que a crítica se circunscreve ao âmbito do exercício livre e autônomo do pensamento, postura que irá nos lembrar mais adiante (Cf. III II, p. 806).
} 
"[B] [...] Je me bande volontiers contre ces vaines circonstances qui pipent nostre jugement par les sens; et, me tenant au guet de ces grandeurs extraordinaires, ay trouvé que ce sont, pour le plus, des hommes comme les autres." (id. ibid.)

A primeira atitude testemunhada "contra as vãs circunstâncias que logram nosso julgamento por meio dos sentidos", é a de recuo voluntário e reserva tensa ("je me bande volontiers"). Montaigne não hesita em desconfiar do aparato e da pompa que sói acompanhar a grandeza. Ele não cede a possível beleza, oca talvez, destas "vãs circunstâncias" que nada demonstram do verdadeiro valor daquele que cercam e paramentam. São da ordem de um ornato exterior e supérfluo, e até mesmo mal intencionado, segundo o parecer aqui expresso, que buscam apenas seduzir e aliciar os sentidos. Como as "contrafações" que Platão denunciava na "toilete", na "culinária", na "retórica" etc - pelas quais Montaigne promène seu pensamento como por lugares retóricos, cuja força persuasiva visa nos convencer da vanidade e perversidade da dissimulação, não em nome de uma "verdade" pura e sem mácula, bloqueada pela crítica cética, mas em prol de uma "verossimilhança" honesta propõem uma aísthesis que oculta uma alma igualmente vã. O combate de Montaigne, que não conta com um esclarecimento definitivo da verdade nem crê na sua possibilidade, mormente no mundo humano travado de imperfeição, se dá no interior do campo das mesmas "verossimilhanças", tentando persuadir-nos da falsa utilidade da mentira, em benefício da honestidade, da ação e da palavra franca e veraz ${ }^{49}$. Não será diferente, adiantemos, no caso da denúncia das suffisances estrangeres, exceto pelo fato de que estas são tentativas de "mobiliar internamente" os esprits, mas frustradas pela falta de "digestão".

Voltemos. Do recuo passa então à guarda ("me tenant au guet"), tendo descoberto - o texto assume o caráter de relato pessoal de uma experiência efetiva - que a maioria é tal como os outros homens, comuns e nada extraordinários, faltando-lhes mesmo o "senso comum", tal como firma Montaigne pela autoridade do riso satírico de Juvenal. Ainda que não falte

\footnotetext{
${ }^{49}$ A passagem lembra-nos as belas páginas que Jean Starobinski dedicou ao estudo da denúncia montaigneana dos malefícios do parecer. Mas aqui diferentemente daquele que foge, saindo da cena povoada de ilusões e aparências, Montaigne ensina a enfrentar a "mentira" destes prestígios de corte e de cátedra.
} 
Fortuna, falta-lhes mesmo freqüentemente o senso, ou seja, nem mesmo são capazes daquela faculdade que já Montaigne, antes de Descartes, no De la praesumption, diz ser a mais bem partilhada entre os homens. Mas Fortuna não distribui seus bens segundo os méritos...

Ora, se não os vemos - porque deixamos de julgar com os sentidos - maiores do que são, por vezes até "os estimamos e percebemos menores do que são", adverte Montaigne. O efeito de distorção se inverte, afastado o aparato que podia iludir. E isto porque "ils entreprennent plus et se montrent plus". Se antes o aparato os ampliava, agora, vistos em relação à tarefa de que se incumbiram, parecem menores. Suas ações são mais freqüentes e visíveis, a visibilidade tendo por razão o próprio caráter público das ações. E por agirem mais e se exporem mais, seu fardo é maior. E nem sempre respondem a este fardo assumido. Nem mesmo se vê o seu justo tamanho, visto que acabam sucumbindo ao peso das responsabilidades assumidas, à dificuldade das ações empreendidas, à visibilidade do posto. Montaigne opera ainda aqui com um lugar: "Il faut qu'il y ayt plus de vigueur et de pouvoir au porteur qu' en la charge" (id. Ibid.). Este lugar-comum, aplicado aqui à política e a lide com as ciências, nos convida a pensar na relação entre a força (vis) e o peso que se ergue e se tem de suportar: peso do governo das coisas ou do manejo dos saberes. A força devendo exceder o peso: Celuy qui n'a remply sa force, il vous laisse deviner s'il a encore de la force au delà, et s'il a esté essayé jusques à son dernier point; celuy qui succombe à sa charge, il descouvre sa mesure et la foiblesse de ses espaules" (id. ibid.). A "carga" opera como critério que mede o quanto de força há naquele que tenta erguê-la, visto que ela pode, seja não exceder a força, caso em que sobra ou é empregada até seu último ponto, seja ultrapassá-la, caso em que se sucumbe e revela a "medida e fraqueza dos ombros". Daí, no que segue, Montaigne considerar duas cargas em relação a duas forças: a do saber em relação aos "sçavantes" e a do governo e comando do mundo em relação aos governantes, a fim de medir seus respectivos "vigores".

Primeiro, a relação com o saber:

"[B] [...] C'est pourquoy on voit tant d'ineptes ames entre les sçavantes, et plus que d'autres: il s'en fut faict des bons hommes de mesnage, bons marchans, bons 
artizans; leur vigueur naturelle estoit taillée à cette proportion. C'est chose de grand poix que la science; ils fondent dessoubs." (id. ibid.)

Montaigne assume aqui como "premissas" de sua argumentação sobre o "descompasso" entre força e peso, por um lado, a idéia de um "vigor natural talhado" em certa proporção; por outro, a do "grande peso" da ciência. Apenas verossímeis (eikós), admitidos e acolhidos pelo leitor suposto de seu discurso, que têm por finalidade dar razões da inépcia dos "sábios competentes". Fundadas ou não num saber da natureza humana, elas comodamente se prestam a estabelecer o ponto em questão. Não passemos, contudo, em silêncio a visão "aristocrática" que tais premissas carregam. Como já flagramos anteriormente na crítica movida contra o uso que se faz das ciências, há implicada nesta reserva com os "sçavantes" uma concepção não apenas de que as ciências e letras recusam o uso servil e venal dos "clercs" e "pedantes", como só encontram seu verdadeiro uso quando manejadas pelas almas reconhecidamente "valorosas", os "esprits bien nées", nos assuntos realmente importantes: na conduta da vida e no governo da coisa pública. Montaigne opera sim com a concepção de uma virtude de poucos, de um "vigor" e "destreza" dos "engenhos", bastante raro, como deixa claro a variação do tema na continuação:

"[...] pour estaller et distribuer cette noble et puissante matiere [sc. la science], pour l'employer et s'en ayder, leur engin n'a ny assez de vigueur, ny assez de maniement: elle ne peut qu'en une forte nature; or elles sont bien rares. [C] Et les foibles, dict Socrates, corrompent la dignité de la philosophie en la maniant. Elle paroist et inutile et vicieuse quand elle est mal estuyée." (id. Ibid., 931-32)

A inépcia resulta, então, de um desequilíbrio entre a "vocação" e destinação inscrita no vigor e na destreza do engenho, talhado pela natureza, e a tarefa que de fato se assume. O curioso e risível aqui é exatamente que os depositários do poder e do saber são exatamente os que são mal talhados pela natureza para os postos que vêm a ocupar efetivamente, segundo a queixa geral que se exprime.

Mas, não pensemos que com esse desencontro entre a natureza e o uso se exime o homem da responsabilidade por esse mal uso da letras. Pelo 
menos no que diz respeito ao uso das letras, a infinita curiosidade inscrita no homem, para seu flagelo, a queixa tem ares de reprovação e regulação. Se Montaigne não dá o passo de reclamar o encontro feliz das naturezas bem dotadas e bem formadas com o governo efetivo das coisas, cujo desencontro ilegítimo e tirânico constata sem deixar de se submeter, na lide com o saber sua atitude é diferente. Ele responsabiliza o homem e sua educação por sua tolice, pois ela tem mais que ver com o governo de si. $E$ isto não porque o mundo é necessário e à nossa liberdade só cabe assentir a esta necessidade sem perturbação, mas porque a fortuna atravessa em sua errância todo projeto. O abalo provocado em seu tempo pela introdução das "nouvelletez" no governo das coisas é visto como mais pernicioso do que o mal menor que é deixar as coisas como estão.

Passemos agora a consideração do exercício do poder, que é posta em pé de igualdade com o que disse sobre o saber quanto a relação "carga"/"força":

"A ceux pareillement qui nous regissent et commandent, qui tiennent le monde en leur main, ce n'est pas assez d'avoir un entendement commun, de povoir ce que nous pouvons; ils sont bien loing au dessoubs de nous, s'il ne sont bien loin au dessus. Comme ils prommetent plus, ils doivent aussi plus" (id.ibid.)

Reforcemos, somente, que "reger e comandar", "ter o mundo nas mãos", demanda um entendimento acima do comum, uma "capacidade" maior que a comum. Caso contrário, no contraste relativo das posições, eles se mostram muito abaixo dos que estão abaixo deles, se não estiverem muito acima. A dimensão de seu "dever", de sua "obrigação" para com os que lhe estão sujeitos, é diretamente proporcional à sua "promessa".

A equação é clara e a comparação entre os dois registros é simples para que se insista mais nela. Interessante é notar o corolário que Montaigne retira desta condição descompassada para a atitude que convém a um príncipe guardar no que concerne ao uso da palavra em certas situações: "et pourtant leur est silence non seulement contenance de respect et gravité, mais encore souvant de profict et de mesnage". E o ensaísta divertidamente ilustra esta conveniência de guardar silêncio em benefício próprio com a "anedota" do rei 
Megabiso no atelier do pintor Apeles, que acaba por ser desprezado até pelos "garçons de boutique" (mais uma vez os moços de oficina) quando se põe a falar de maneira impertinente sobre a pintura, quando, antes, devido a sua "pompa e colares" parecia aos olhos deles "grande coisa". O rei deveria ter mantido, calado, sua "externe et praesomptive suffisance". Diante do especialista hábil, que julga com conformidade as qualidades dos objetos de sua arte, porque dotado de um saber técnico que compete à sua produção, o biombo dos "magníficos atavios" ("atours") e do "grande aparato" ("estat") não basta para ocultar uma "ignorance populaire", quando se põe a falar. As "almas tolas", como arremata aguda e sarcasticamente, servem-se amiúde de um "semblante frio e taciturno" a título de "prudence et capacité".

O texto parece inegavelmente escorregar, com o exemplo do rei, para uma consideração sobre "competências" que não esperaríamos ver atribuída a quem "comanda e rege", visto que a pintura pertence a um âmbito especializado de que a política não participa. Poderíamos nos perguntar em que medida os que têm o mundo nas mãos estão na dependência de um saber e de uma capacidade que Ihes confira mérito para ocupar tais posições: ou seja, se falamos em mérito, necessariamente pensamos numa capacidade que não é meramente dom ou sobrevém ao acaso, mas depende do esforço e implica qualidades que o sujeito moral forjou em si mesmo. Prudência e habilidade na condução dos assuntos públicos dependeriam assim de uma "formação". E os cargos e dignidades seriam distribuídos - não fosse o acaso a designar os que os ocupam e possuem, como logo irá explicitar - segundo as qualidades ou virtudes que habilitariam a tais incumbências. Guardemo-nos de qualificar tais virtudes, intelectuais ou morais, e observemos, por ora, que o diagnóstico de Montaigne é bem outro e que sua atenção recai na arbitrariedade da distribuição. E que o que a anedota quer ilustrar, portanto, é a oposição entre a tolice e as impertinências que produz, de um lado, e a prudência e capacidade reais que habilitam a falar com pertinência sobre algo, de outro. Em suma, ela acentua somente o desencontro entre "posição" e "prudência ou capacidade", advertindo ainda sobre o proveito do silêncio nestas circunstâncias.

Finalmente, Montaigne declara com todas as letras que "as dignidades, os cargos, se dão necessariamente mais por fortuna do que por 
mérito", mas diz isto para imediatamente acrescentar que seria erro imputar aos reis a responsabilidade por essa "má escolha". (A própria escolha do rei, aliás, está sutilmente implicada nesta escolha do acaso e da fortuna, também eles não escolhidos por mérito.) Eles não poderiam escolher melhor. Da imputação e acusação sutil de que não tem um entendimento acima da média nem podem mais do que nós outros, homens de entendimento comum, Montaigne passa a desculpá-los e entra a discutir em que condições idealíssimas poderiam fazê-lo. Leiamos o texto:

"[B] [...] Au rebours, c'est merveille qu'ils y [sc. na distribuição das dignidades e cargos] aient tant d'heur, y ayant si peu d'adresse:

[C] Principis est virtus maxima nosse suos;" (id. ibid.)

È maravilha, bem entendido, que escolham bem os que ocuparão os cargos e dignidades, que sejam felizes nisso - e de modo complementar que haja felicidade, para os súditos no caso, na escolha que a fortuna opera de seus reis - visto que não tem recursos, meios de discernir, capacidade de escolher pelas qualidades e méritos. A citação de Marcial intercalada em acréscimo lembra que no conhecimento dos súditos - e o texto deixará claro de que conhecimento se trata - está a virtude máxima do governante, mas imediatamente emenda: " $[B]$ car la nature ne leur a pas donné la veuë qui puisse estendre à tant de peuples, pour discerner de la precellence, et perser nos poitrines où loge la cognoissance de nostre volonté et de nostre meilleure valeur". O conhecimento, realizado e encarnado na virtus maxima, e que a natureza não dá, é o de uma vista que pudesse se estender a tão numerosos súditos, para pinçar do meio da multidão os que "excelem" e encarregá-los das tarefas em que excelem. Seria preciso discernir a "excelência", e penetrar os corações ("poitrines") onde se aloja a vontade deles e seu melhor valor. Somente cumprindo a alta exigência deste conhecimento, somente encarnando esta virtus aguda, capaz de sondar nos "peitos" e apreender vontade e valor, é que se escolheria verdadeiramente segundo o mérito. Carentes, porém, deste discernimento, os reis estão obrigados a "trier par conjecture et à tatons, par la race, les richesses, la doctrine, la voix du peuple: tresfoibles argumens". Fracos 
e exteriores, por oposição a interioridade e intimidade que se mostrariam à clarividência daquele saber que não tateia e que em sua solidez e certeza fundaria "une parfaite forme de police", já que julgaria "par justice" e escolheria os homens "par raison".

O prosseguimento imediato do texto nos mostra, todavia, que as alegações até agora avançadas não satisfazem plenamente o estabelecimento da tese de que o "acaso" distribui sem mérito os cargos. Montaigne passa, então, a examinar uma objeção fundada no "sucesso": "ouy, mais il a mené à point ce grand affaire". O sucesso, isto é, ter levado a bom termo um "affaire", seria, segundo a voz que o interpela - todo o trecho que analisamos mimetiza uma conversa e o pensamento como se move sob a pressão das oposições -, sinal de mérito e capacidade. A que Montaigne de pronto responde: " $C$ 'est dire quelque chose, mais ce n'est pas assez dire: car cette sentence est justement receuë, qu'il ne faut pas juger les conseils par les evenemens". A resposta traz à baila a célebre regra, discutida já por Montaigne no capítulo Que l'intention juge nos actions, que estabelece que a excelência moral nas ações deve ser julgada não pelas conseqüências das ações empreendidas, os "evenemens", mas pela qualidade da deliberação realizada e retidão da escolha a que se chega: em uma palavra, pela intenção. Daí vir a concluir, duas páginas depois, que "les evenemens sont maigres temoings de nostre pris et capacité". Antes, porém, se aplica em apoiar a "sentence justement receuë" por razões que tocam, sobretudo, à interferência do "acaso" nas ações. Donde, adiantemos, extrai a conseqüência de que "os mais simples" com suas razões mais "rasas, baixas, frouxas e batidas" tem mais êxito nos "affaires", bem como o ataque correlato à presunção da "humana prudência".

Voltemos a acompanhar o texto. O desdobramento feliz de um caso, de uma empreita, não deve ser atribuído à qualidade do cálculo, retidão da vontade e da decisão do agente, seja nos assuntos públicos, seja nos privados. Sucesso ou felicidade na consecução de fins buscados não devem ser imediatamente atribuídos à excelência do agente, de sua deliberação e escolha de meios eficazes. È preciso precaver-se e sondar se não foi a Fortuna que os obteve para ele, pois, o curso sinuoso dos envenemens, em que se assiste o soerguimento de uns e derrubada de outros, não é razão suficiente para julgar 
a qualidade daquele que assumia a iniciativa de governá-lo. È o que nos confirma as menções aos cartagineses e romanos:

"[C] Les Carthaginois punissoient les mauvais advis de leurs capitaines, encore qu'ils fussent corrigez par une heureuse issue. Et le peuple Romain a souvent refusé le triomphe à des grandes et tres utiles victoires par ce que la conduite du chef ne respondoit point à son bonheur." (id. ibid.)

Independentemente da "correção" que um "feliz desenlace" ("hereuse issue") pudesse trazer a uma "má decisão" ("mauvais advis") de seus capitães, não se abstinham aqueles de punir; à despeito das "grandes e assaz úteis vitórias" de seus generais, estes recusavam-lhes o triunfo em função da incompatibilidade entre sua conduta e sua "ventura" ("bonheur"). Dois exemplos da aplicação da mesma regra, que impõe que no juízo moral e na atribuição do louvor e do mérito considerem os homens prudentes e judiciosos, se eles verdadeiramente assentam no agente, que deve agir voluntariamente e com conhecimento de causa, tendo antes deliberado e escolhido de bom grado agir assim e inscrever na ordem do mundo a sua escolha, pois

"[B] on s'aperçoit ordinairement aux actions du monde que la fortune, pour nous apprendre combien elle peut en toutes choses, et qui prent plaisir à rabatre nostre presomption, n'aiant peu faire les malhabiles sages, elle les fait heureux, à l'envy de la vertu. Et se mesle volontiers à favoriser les executions où la trame est plus purement sienne." (id. ibid.)

Ventura, sucesso, felicidade são um dom gratuito da fortuna, nesta percepção "prudente" - mas aqui não sem algum laivo de riso que zomba de uma certa prudência dos prudentes e da virtude dos virtuosos, aquela que tenta "abraçar causas e conseqüências" - do que ordinariamente ocorre nos assuntos humanos. Fortuna que mostra seu poder e investe contra a presunção dos homens e a rebate, oferecendo seus presentes antes aos "malhabiles" do que aos "sages", precisamente porque, não podendo tornar sábios, faz felizes estes homens estultos, desafiando e afrontando a própria "virtude". Neste auxílio e favor dispensados, a fortuna, ciosa do poder que tem de interferir nas iniciativas humanas, conduz a bom termo de preferência as 
"tramas" que são mais puramente suas, ou seja, quanto mais agudo e perspicaz o cálculo, quanto melhor e mais correta a escolha, quanto mais "virtude" estiver empenhada num cometimento, menos o homem conta com as benesses desta deusa "zelosa" de suas prerrogativas. E, ao contrário, quanto mais obtuso e cego o ator, maior o favor.

Por apresentar argumentos que assumem um tão alargado papel da fortuna, Montaigne, num próximo lance, acaba por explicar por que razão "os mais simples dentre nós" todos os dias chegam ditosos ao fim de grandes "empresas" ("besongnes"), sejam eles públicos, sejam privados, iniciando um ataque a prudência humana com muitas nuances e modulações até o final deste excurso. É de notar, no entanto, que tais argumentos aparentemente contrários à "habilidade e perícia" na consideração dos meios possíveis e eficazes para a obtenção de fins, no fundo, pretendem menos desqualificar o homem de prudência do que advertir aqueles que julgam as ações humanas da dificuldade em atribuir louvor a um homem. Montaigne não entra aqui a elogiar a estultície, o que seria flagrante contradição com o teor mesmo de todo capítulo, já que em conversação mostrava toda sua irritação com a inépcia dos tolos. O propósito de todo movimento sendo exatamente o de desmascará-la em sua aparente capacidade. É o que a comparação dos insucessos dos negócios de Siranez, o Persa, com os sucessos dos "inábeis", deixa transparecer:

"[B] [...] Et comme Siranez le Persien respondit à ceux qui s'estonnoiet comment ses affaires succedoient si mal, veu que ses propos estoit si sages, qu'il estoit seul maistre de ses propos, mais du succez de ses affaires c'estoit la fortune, ceux-cy peuvent respondre de mesme, mais d'un contraire biais." (id. ibid.)

É por um viés contrário que os inábeis responderiam, pois, enquanto Siranez alega poder e dominar (ele é mestre) somente seus "propósitos", não podendo nada sobre o mal-sucesso de seus negócios, já que a fortuna nisso é quem comanda, aqueles devem a fortiori todo bom-sucesso dos seus assuntos somente a ela e nada aos seus "propósitos".

Vista da perspectiva não mais dos agentes, mas das coisas expostas às múltiplas e imprevisíveis interferências da causalidade acidental e errante da 
Fortuna, esta condição leva Montaigne, não satisfeito, a aduzir ainda um segundo e breve argumento de que irá extrair conseqüências para o pretenso governo do mundo: "La plus part des choses du monde se font par elles mesmes, Fata viam inveniunt". Se no primeiro acentuava a participação do acaso, neste emprega a força da necessidade e do destino em quase todas as coisas que se produzem no mundo ${ }^{50}$, advertindo mais uma vez que o êxito deve ser separado do mérito, já que "os destinos encontram seu próprio caminho", como lembra o verso de Vergílio que cita, e que o homem apenas se ilude ao pensar que por meio de sua ação dá aos acontecimentos do mundo um rumo outro, quando as coisas acontecem à sua revelia. Argumento sutil e complementar ao primeiro, mas que tende, ao estreitar e restringir mais ainda 0 domínio que se tem sobre o curso das coisas, a destacar a dificuldade que há em atribuir mérito real a alguma conduta, não se distinguindo bem pelo que há de exterior e aparente nas ações uma verdadeira suffisance.

Não importa se argúi uma necessidade ou mesmo uma completa acidentalidade dos eventos, o que interessa é que Montaigne queira desmascarar o desenlace feliz que se vê carregado de "autoridade", mas que oculta "souvent une tresinepte conduite". O que mitiga enormemente que se pretenda aliar êxito e governo da razão: "[B] [...] Nostre entremise n'est quasi qu'une routine, et plus communéement consideration d'usage et d'exemple que de raison"(id. ibid.). Num mundo indiferente às iniciativas de conduzi-lo, ou num mundo que as frustra pelo encontro fortuito de linhas causais, o sucesso quase sempre não é capaz de revelar mais do que a "rotina", "consideração de uso e exemplo" de "nostre entremise", nunca o governo racional das coisas, algo que ultrapasse a "imitação" do uso e exemplo que qualificam certa "rotina", por oposição a uma experiência profundamente meditada e avisada, que pondera racionalmente as possibilidades, prevê e articula com eficácia os meios em

\footnotetext{
${ }^{50}$ Não acreditemos, contudo, que Montaigne assuma de alguma maneira uma ou outra das teses "cosmológicas" implicadas nestas argumentações, quais sejam, ou a de um mundo desordenado em que tudo ocorre por acaso e que, portanto, impede que o homem possa inscrever sua ação neste mundo com alguma esperança de obter o fim que visa; ou a de um mundo em que tudo está absolutamente determinado, em que ele apenas sonha que dá rumos aos eventos, que se fazem por si mesmos e são indiferentes a sua intromissão. O ceticismo de Montaigne barra qualquer afirmação deste tipo. Ele opera aqui apenas com sua capacidade de produzir discurso antitético.
} 
vista de seus fins ${ }^{51}$. Ele não tem nada da "previdência" que, no mais, se vê obstruída aqui pelas argüições do Ensaísta. Apóia-se como cegamente num sucesso passado e o imita na esperança de igual sucesso. Sucesso, porém, que não traz marca do que lhe estaria por trás: habilidade ou inabilidade.

Por isso mesmo, Montaigne volta a considerar os "motivos" e os "procedimentos" empregados no affaire" que Ihe havia sido objetado:

"[B] [...] Estonné de la grandeur de l'affaire, j'ay autrefois sceu par ceux qui l'avoient mené à fin leurs motifs et leur addresse: je n'y ay trouvé que des advis vulgaires; et les plus vulgaires et usitez sont aussi peut estre les plus seurs et plus commodes à la pratique, sinon à la montre." (id. ibid.)

Informando-se com os próprios atores, pôde concluir que empregaram somente "des advis vulgaires". Mas isso não os desqualifica aos olhos de nosso autor, que acaba por sustentar que, tanto para a "prática" como para a "exibição", talvez sejam "mais seguros e cômodos" os "mais vulgares e usitados" meios: "Quoy, si les plus plattes raisons sont les mieux assises, les plus basses et lasches, et les plus battues, se couchent mieux aux affaires?". Entendemos facilmente pelo que ficou dito acima sobre a fortuna que a "prática" peça mais a "rotina" do que a penetração aguda das considerações de prudência. Elas são vãs, na medida em que são impotentes. E Montaigne reforça ainda mais esta argumentação logo adiante:

"[B] [...] L'heur et le mal'heur sont à mon gré deux souveraines puissances. C'est imprudence d'estimer que l'humaine prudence puisse remplir le rolle de la fortune. Et vaine est l'entreprise de celuy qui presume d'embrasser et causes et consequences, et mener par la main le progrez de son faict; vaine sur tout aux deliberations guerrieres." (id. ibid.)

Mas por que seguras e cômodas "à la montre"? A consideração é de "prudência", mas numa acepção outra daquela cuja vanidade acabara de atacar. Ela concerne a "conservação da autoridade do Conselho dos Reis": "[B] [...] il n'est pas besoing que les personnes profanes y participent et y voyent

\footnotetext{
${ }^{51}$ O procedimento por "rotina" não mostra vínculo entre êxito na consecução do fim e os meios empregados, nem é capaz de dar as razões destes meios.
} 
plus avant que de la premiere barriere. II se doibt reverer à credit et en bloc, qui en veut nourrir la reputation" (id. ibid.). O olhar indiscreto e profano que ultrapassa certas barreiras tenderia a revelar algo do mistério que cerca este exercício que muitos até deificam (Cf. a anedota sobre os mexicanos - id. ibid., p. 935). É a própria legitimidade e fundamento do exercício do mando que seria afetada por uma perscrutação excessiva e inconveniente, parece nos avisar Montaigne. Que em suas embaixadas procede de modo diverso, um traço a mais da objeção que lança diretamente contra os querem "abraçar as causas e conseqüências" e "conduzir pela mão os progressos de seu feito": "Ma consultation esbauche un peu la matiere, et la considere legierement par ses premiers visages; le fort et principal de la besongne, j'ay accoustumé de le resigner au ciel".

Mas, não vamos insistir no sentido deste mistério, o que estaria um pouco "fora de nosso propósito". Passemos à consideração da conseqüência máxima da interferência da fortuna que Montaigne vem alegando. Vimos como ele desautoriza toda prudência que se confunda com cálculo e pretenda 0 controle dos passos na condução de um feito. Se até aqui, contudo, sua intromissão se dava no curso dos envenemens, a ingerência dela agora é interiorizada e levada para dentro da própria "sagesse et consultation", atrapalhando a atividade interna do cálculo prudencial e imiscuindo-se no domínio da vontade e no exercício da própria racionalidade, cujos movimentos se governam sem nós muita vez:

"[B] [...] Je dis plus, que nostre sagesse mesme et consultation suit pour la plus part la conduicte du hazard. Ma volonté et mon discours se remue tantost d'un air, tantost d'un autre, et y a plusieurs de ces mouvemens qui se gouvernent sans moy. Ma raison a des impulsions et agitations journallieres [C] et casuelles." (id. ibid.)

O ponto é delicado, se levarmos em conta a exigência que todo o De l'art de conferer põe para o exercício autônomo do pensamento e do julgamento. Não há como escamotear que tudo oscila. Como pretender que não é escusável conduzir mal a busca, se a razão e o discurso, bem como a vontade, estão sujeitos a tais "impulsos e agitações diárias e casuais"? Como 
entender a suffisance como uma potência capaz de ordenar e conduzir prudentemente a conversa, se mesmo uma "teste bien faicte" está sujeita a tais assaltos do acaso? Mas não estaria presente neste reconhecimento da própria fragilidade o impulso que move à realização da "belle courses"? Mais adiante veremos como Montaigne se lamenta da segurança e contentamento do tolo que acredita sair-se vitorioso do combate, quando a prudência o manda de volta para casa sempre descontente. O contentamento será tomado como indício máximo de tolice.

Volta, por fim, a reiterar a separação de "êxito" e "habilidade" no exercício do poder:

"[B] [...] Qu'on regarde qui sont les plus puissans aus villes, et qui font mieux leurs besongnes: on trouvera ordinairement que ce sont les moins habiles. II est advenu aux femmes, aux enfans et aux insensez, de commander des grands estats, à l'esgal des plus suffisans Princes. [C] Et y rencontrent, dict Thucydides, plus ordinairement les grossiers que les subtils. [B] Nous attribuons les effects de leur bonne fortune à leur prudence." (id. ibid.)

Findo o desvio das "duas tiranias" (a "parliere" e a "effectuelle"), reata-se a discussão anterior com a observação sobre a "elevação em dignidade", que destaca um homem da multidão com a mera mudança da sorte, e a simultânea variação nos juízos, que levam em conta a "prerrogativa da posição" ("rang"):

"Or j'estois sur ce point, qu'il ne faut que voir un homme eslevé en dignité: quand nous l'aurions cogneu trois jours devant homme de peu, il coule insensiblement en nos opinions une image de grandeur, de suffisance, et nous persuadons que, croissant de trein et de credit, il est creu de merite. Nous jugeons de luy, non selon sa valeur, mais, à la mode des getons, selon la prerogative de son rang." (id. ibid.)

A mudança "imprime" ("coule") nas opiniões uma "imagem de grandeza" e de "suffisance", que não tinha "três dias antes". O efeito, com o crescimento do status ("trein") e do "crédito", é de persuasão. Com o próprio movimento de elevação (mutação pura e simples operada pela fortuna em sua 
distribuição arbitrária de dons, de que estamos avisados) ocorre um outro trânsito, outra translação, agora da opinião e julgamento dos que assistem o giro da roda da fortuna. Embora ele não tenha sido colocado aí por mérito, sua nova posição é imediatamente interpretada como se devendo à capacidade e valor especiais que para lá o teriam alçado. Mais uma vez, esta alteração "insensível" da dóxa ocorre por se ater o juízo à superfície aparente e desconsiderar a variação das condições no tempo. Aqui, mais do que distorção, aponta-se um esquecimento. Ela não guarda a memória do que foi, se escravizando ao presente pontual oferecido a nós pelos sentidos. Mudam as aparências, a opinião muda juntamente, já que nela vem sempre se espelhar o que vê, e somente o que vê: os acidentes externos presentes. Daí variarem novamente os juízos, mas em sentido contrário, quando muda a sorte:

"[B] [...] Que la chanse tourne aussi, qu'il retombe et se remesle à la presse, chacun s'enquiert avec admiration de la cause qui l'avoit guindé si haut. Est-ce luy? faict on; n'y sçavoit il autre chose quand il y estoit? les Princes se contentent ils de si peu? nous estions vrayment en bonnes mains! C'est chose que j'ay veu souvant de mon temps." (id. ibid.)

A par da denúncia tácita da tolice deste juízo sensível e da crítica de sua inépcia, Montaigne apõe a sua memória e experiência de tais mutações: é coisa que viu freqüentemente em seu tempo, sem deixar, ele que tanto se queixa da sua falta de memória, de registrar e de tirar lições.

O que segue reitera o efeito de obnubilação das aparências sobre os sentidos em mais de um registro. Assim, no caso das "mascáras de grandezas" nas comédias, que tocam e logram; assim também, na resposta de Melântio sobre o efeito da linguagem excessiva, na tragédia do tirano Dionísio, que fornece a pedra de toque para os que quisessem julgar os "discursos dos grandes". Aquele responde que não a viu pela ofuscação de sua linguagem, como estes deveriam dizer: "Je n'ay point entendu son propos, tant il estoit offusqué de gravité, de grandeur et de majesté". Como na linguagem empolada que impede de ver os casos que são narrados, nos discursos o entendimento do "propos" acaba por se perder em meio ao aparato. No reparo sobre o cortejo de adoradores, encontramos, por fim, o corretivo - passagem famosa - para as 
"ilusões" dos sentidos: "[B] [...] Ce que j'adore moy-mesmes aus Roys, c'est la foule de leurs adorateurs. Toute inclination et soubmission leur est deue, sauf celle de l'entendement. Ma raison n'est pas duite à se courber et flechir, ce sont mes genoux". O exercício da obediência devida aos reis, não faz dele um "adorador" como os outros, pois curva e dobra somente os "joelhos", não sua "razão" e "entendimento".

As duas anedotas, a de Antístenes e o asno e a da canonização dos reis, que seguem antes do encerramento deste movimento, reafirmam respectivamente a desvinculação entre a "função" e a "capacidade", e a fragilidade que se oculta por trás dos mistérios do exercício do poder (ironicamente, a canonização e deificação impedem de sondar a aptidão).

Por fim, afirma-se Montaigne diverso desta "façon commune" de julgar, desconfiando da "suffisance", "quand [il] la voi[t] accompaignée de grandeur de fortune et de recommandation populaire", reiterando seu gosto pela conversa entre iguais, ao lembrar que se "mantém em guarda" frente à "aparente" superioridade dos que, por causa de sua autoridade, falam quando querem, escolhem seu momento, rompem a discussão ou mudam-na com autoridade magistral e defendem-se das oposições com um movimento de cabeça, um sorriso ou um silêncio, tudo isso diante de uma assistência reverente e temerosa. Pura afirmação de um poder da posição.

\subsection{Suffisances estrangeres}

Voltamo-nos a partir de agora à apresentação de um segundo preceito, concernente à avaliação da mesma suffisance, pois, há ainda um outro escolho a considerar: o do saber de empréstimo. A "força" das almas que se confrontam por ocasião da conversa permanece como o foco de interesse, já que se considera ainda este aspecto particular da manière, tomada agora pelo viés da assimilação e "apropriação" dos saberes, no processo formador da capacidade e autonomia do pensamento e do julgamento. Se, no passo anterior, Montaigne advertia-nos para não julgar os homens por sua aparência externa, uma vez que sua condição, suas dignidades, seus cargos e funções, em suma, sua posição no corpo social e político iludiam e enganavam nossos sentidos, afastado aquele primeiro obstáculo, ocupar-nos-emos daqui em 
diante com uma outra advertência que diz ser de "grande utilidade": refere-se às "produções do espírito" exteriorizadas por "palavras" ("mots"), bem como ao tipo de "relação" que os homens demonstram ter com os "saberes", avaliados por meio da capacidade de articular um discurso mais uma vez pertinente. Vejamos como procede, sempre no rastro da trama do Ensaísta.

"[B] [...] Voicy un autre advertissement duquel je tire grand usage: c'est qu'aus disputes et conferences, tous les mots qui nous semblent bons ne doivent pas incontinent estre acceptez. La plus part des hommes sont riches d'une suffisance estrangere" (id. ibid., p. 936)

Mais uma vez o que está em jogo é evitar a precipitação que julga as qualidades do homem a partir de certas manifestações suas. Daí, o aviso para precavermo-nos, "em disputas e conversações", e não aceitarmos incontinenti "todas as palavras que nos parecem boas", dada a "suffisance estrangere" de que a maioria dos homens é rica. O termo "estrangere" nos remete - o que o prosseguimento da discussão deixará claro - a oposição entre o "alheio" e o "próprio" nas alegações, e o texto já de início nos sugere que estará em causa uma suposta "riqueza" dos homens. Ainda que se reconheça o "valor" de um "dito", ainda que uma alegação, por si mesma, pareça boa, sua qualidade intrínseca não serve de critério para avaliar quem a enunciou, visto que "il peut advenir à tel de dire un beau traict, une bonne responce et sentence, et la mettre en avant sans en cognoistre la force" (id. ibid.). Logo, ela não é, por si só, indício seguro de suffisance. Será preciso, portanto, sondar de que modo este esprit se relaciona com a correta e boa "opinião" que, talvez por acaso, exprime. E manter-se em guarda e atento antes de concluir da bondade e valor do homem, quando se pode estar diante apenas de algo que é, de fato, bom, sem que seja aquele que o diz bom igualmente: "[B] II n'y faut point tousjour ceder, quelque verité ou beauté qu'elle ait" (id. ibid.). E isto porque resta sempre a possibilidade de avançar "uma boa resposta e sentença" sem, de fato, vimos, "conhecer sua força", tendo-a tomado simplesmente de empréstimo.

E o Ensaísta jocosamente brinca com sua própria advertência ao voltar-se para si e reparar, num acréscimo em camada [C], poder-se talvez 
verificar por ele mesmo que "não sustentamos tudo o que tomamos de empréstimo". Refere-se claramente aos "furtos" das auctoritates do passado, dos escritores que freqüenta e lê, comércio de que abundantemente os letrados e filósofos da época se alimentam, e a que ele próprio não se furta, e que está na origem de seus Ensaios ${ }^{52}$.

Passa, então, aos "meios" que propõe para avaliar o vínculo entre o esprit e os seus "dizeres". Como orienta proceder Montaigne diante de uma boa resposta ou sentença, cheia de verdade ou beleza, mas que não sabemos como "se aloja" em seu portador? De dois modos: "[B] [...] Ou il la faut combatre à escient, ou se tirer arrière, soubs couleur de ne l'entendre pas, pour taster de toutes parts comment elle est logée en son autheur" (id. ibid.). O primeiro expediente proposto é o de confrontar, partir cientemente ("à escient") para o ataque da "proposição" alegada. O outro, é o de recuar, fingindo não entender.

Imediatamente Montaigne acrescenta, lembrando as vezes em que, igualmente, avançou um "beau traict" sem lhe conhecer devidamente o peso, que os "revides ou réplicas" ("revirades") que empregava, "na necessidade e pressão do combate", haviam "ferido" mais do que desejava e esperava: "[B] [...] II peut advenir que nous nous enferrons, et aidons au coup outre sa portée. J'ay autrefois employé à la necessité et presse du combat des revirades qui ont faict faucée outre mon dessein et mon esperance: je ne les donnois qu'en nombre, on les recevoit en pois" (id. ibid.). As investidas, sem que soubesse, atingiam o adversário, que se feriria menos, se não tivesse acusado a força com que as recebia, quando elas eram dadas somente "em número" por Montaigne. Ou seja, os "contra-golpes" que alegava "na necessidade e pressão", sem serem devidamente ponderados por ele, tinham surpreendentemente a seu favor mais do que a "quantidade". Mas, o adversário

\footnotetext{
${ }^{52}$ Como bem demonstrou Pierre Villey ao ligá-los no início à prática das compilações do gênero leçons (Cf. "Les Sources et l'Évolution des Essais de Montaigne". Paris: Hachette, 1933). Montaigne nos confessa e dá a conhecer suas duas fontes principais em filosofia: Plutarco e Sêneca. E basta passar os olhos pelos Ensaios para ver o quanto eles se alimentaram e enriqueceram, não só destes autores confessados, não só de Filosofia, como também da Historiografia e da Poesia antigas, e ainda de outros gêneros, estabelecendo um cerrado diálogo com o conjunto das Letras legadas pela antiguidade, no que, aliás, repete o gesto do seu tempo. Como diz Hugo Friedrich, no capítulo que dedica ao estudo das fontes e relações de Montaigne com a Literatura do passado, "uma riqueza imensa acumulou-se nos Essais" (Cf. "Montaigne". Paris: Gallimard, 1968, p. 43).
} 
os recebia percebendo seu "peso", seu alcance, sua força argumentativa, e acusando em sua reação esta força. A observação, portanto, prudentemente norteia o emprego dos dois expediente, pois lembra que não se deve imediatamente conceder ao interlocutor o benefício de conferir ao seu argumento todo peso que ele comporta, sem antes saber se ele mesmo reconhece a força do que avançou: ele pode ter em mãos "belles armes", mas elas são "mal empunhadas", como adiante dirá. É preciso conferir se ele é, de fato, suffisant. E não se dar por vencido antes desta sondagem.

Aprofunda, então, a consideração dos expedientes, propondo-nos uma comparação com a conversa com os esprits vigoureux, do tipo que encontramos no início de nosso percurso, quando da imagem da "contenda" com o "roide jousteur":

"[B] [...] Tout ainsi comme quand je debats contre un homme vigoureux je me plais d'anticiper ses conclusions, je luy oste la peine de s'interpreter, j'essaye de prevenir son imagination imparfaicte encores et naissante (l'ordre et la pertinence de son entendement m'advertit et menace de loing), de ces autres je faicts tout le rebours: il ne faut rien entendre que par eux, ny rien presupposer." (id. ibid.)

A "ordem e pertinência" do "entendimento" do "homem vigoroso" permitem prazerosamente "antecipar" conclusões, "poupar" que ele mesmo "se interprete", "prever sua imaginação ainda imperfeita e nascente", ou seja, quando ele nem mesmo chegou a formular aquilo que tinha a dizer, a extrair as conseqüências do vinha dizendo, a explicar e esclarecer o que alegou, o outro, já é capaz, devido ao encadeamento ordenado e pertinente de suas razões, de prever o que virá em seguida, o que ainda nem ganhou forma acabada, o que nem foi concebido e nasceu. A força deste entendimento propicia uma quase "fusão" entre os entendimentos dos interlocutores, que literalmente, pensam juntos, como uma só cabeça. Mas não pensam o mesmo, já que o "entendimento" do interlocutor "adverte e ameaça" minha posição "de longe". "De longe", bem entendido, sem que se tenha aproximado ainda das razões e proposições que poderiam colocar em causa, em dificuldade, e, no limite, refutar a posição do outro. 
Não é desta atitude de antecipação, contudo, que Montaigne lança mão diante dos supostos homens de suffisance estrangere ("ces autres"); exatamente o contrário: não colabora, seja atacando-o sem revelar ao adversário o alcance da arma que ele "saca" - e que usa mal -, seja fazendose de desentendido, sem nada pressupor por eles. Quando no primeiro caso os pressupostos, implicações e conseqüências, mais ou menos próximos ou distantes, iam sendo antevistos pela força e coesão da trama conceitual ordenada e pertinente de um pensamento solidamente articulado e encadeado, no caso destes tudo o que entende é tão-só o que eles entendem, e não pressupõe nem adianta nada, a fim de sondar como esta "bela concepção" veio se "hospedar" nesta cabeça, e se não se trata de uma "sentença" solta, um enunciado de que se desconhece o alcance. O que explica por que Montaigne propõe este expediente é o fato de que uma "sentença", verse ela sobre conteúdo "teórico ou prático", pode ter um valor e um peso pela "verossimilhança" que porta em si, mas esta "verossimilhança" não é bem avaliada e estabelecida se não for apreendida dentro da rede de articulações, remissões, encadeamentos que arrasta consigo e que a "pertinência" de alguns enseja pressentir e até adivinhar.

Esta espécie de avaliação por recuo desdobra-se em duas formas, conformes à "proposição" que se apresente: se julgam algo em "parolles universelles", ou se dizem "une bonne chose". Na primeira hipótese, pede-se circunscrição e restrição, para ver como chegaram até sua formulação, recuando, por assim dizer, nas razões que levaram até o juízo; na segunda, pede-se não apoiar e deixar seguir, para ver até onde conhecem o que dizem, ou modificar um pouco, para ver se ainda reconhecem o que disseram, avançando e desdobrando o que foi dito. Não é difícil perceber que o exame consiste em pedir que se percorra num ou noutro sentido a cadeia de mediações que apóiam a "proposição", cujo acerto não se discute, mas de cuja compreensão plena por parte de quem acerta se duvida.

Examinemos os textos. "[B] [...] S'ils jugent en parolles universelles: Cecy est bon, cela ne l'est pas, et qu'ils rencontrent, voyez si c'est la fortune qui rencontre pour eux" (id. ibid.). O acerto de juízo, em certo sentido, não se questiona, o juízo é certo ("ils rencontrent"), ainda que amplo e geral e, por isso, pouco preciso. A dificuldade está em saber se o acerto do juízo deve ser 
atribuído a quem julga ou à sorte ("fortune"), precisamente porque sua generalidade facilita o acerto. Acerta-se a direção, não o alvo. Daí demandar que se proceda à "circunscrição e restrição", perguntando-se a "razão" e a "via" que o levou a assim julgar: [C] Qu'ils circonscrivent et restreignent un peu leur sentence: pourquoy c'est, par où c'est" (id. ibid.). Sem que se percorra o caminho anterior das mediações que expliquem o juízo geral que se exprime, explicitando as razões que levaram a assim julgar, são recusados estes mesmos juízos soltos. A prova que se pede do seu acerto, enfatizemos, consiste exatamente no pertencimento em sua inteireza lógico-discursiva ao sujeito, que assim daria mostras de sua "compreensão", "competência" e "habilidade" no trato com tais discursos, qualidades que aderem àqueles que souberam digerir lições e experiências.

O expediente dá ocasião a Montaigne de inserir uma breve reflexão sobre o exercício de julgar:

"[C] [...] Ces jugements universels que je vois si ordinaires ne disent rien. Ce sont gens qui saluent tout un peuple en foulle et en troupe. Ceux qui en ont vraye cognoissance le saluent et remarquent nommément et particulierement. Mais c'est une hazardeuse entreprinse. D'où j'ay veu, plus souvent que tous les jours, advenir que les esprits foiblement fondez, voulant faire les ingenieux à remarquer en la lecture de quelque ouvrage le point de la beauté, arrestent leur admiration d'un si mauvais choix qu'au lieu de nous apprendre l'excellence de l'autheur, il nous apprennent leur propre ignorance. Cette exclamation est seure: Voylà qui est beau! ayant ouy une entiere page de Vergile. Par là se sauvent les fins. Mais d'entreprendre à le suivre par espaulettes, et de jugement expres et trié vouloir remarquer par où un bon autheur se surmonte, par où se rehausse, poisant les mots, les phrases, les inventions une apres l'autre, ostez vous de là. Videndum est non modo quid quisque loquatur, sed etiam quid quisque sentiat, atque etiam qua de causa quisque sentiat." (id. ibid., p. 936-7)

Montaigne desqualifica - fazendo escorregar o seu vocabulário de novo para as sendas da política -, os "julgamentos universais", isto é, os juízos que se atém ao enquadramento e inclusão de particulares em idéias ou conceitos muito gerais. O bom governante não conhece a sua gente "en foulle et en troupe", mas os "saúda e nota" pelo nome próprio e em particular, tal como exigia a virtus maxima, que, contudo, vimos que não encarna em 
nenhum governante real. A "empresa", contudo, é arriscada e desaconselhável ("ostez vous de là") e pressupõe espíritos "fortemente fundados", como ainda uma vez nos adverte, não a doutrina, mas a "experiência" do Ensaísta, ao notar que, por bancarem o "engenhoso", quantos, "foiblement fondez", ao tentar indicar na leitura "le point de la beauté", acabam escolhendo mal onde "deter a admiração" e se revelando "ignorantes" em vez de nos "instruir sobre a excelência do autor" comentado. E zomba dos refinados que diante de uma página de Vergílio se contentam em dizer "eis como é belo!". Os difíceis critérios e procedimentos de um "jugement expres et trié", minudente e detalhado ("par espaulettes"), que queira mostrar "por onde um autor se supera, por onde se realça" remetem ao duplo labor, retórico evidentemente, de pesar as "invenções" e a "elocução" ("mots", "phrases") do discurso que se examina. Por "invenções" entenda-se: o que se pensa, ligadas ao labor das res; por "elocução", igualmente: como se exprime em palavras e frases o que se pensa, ligada ao labor dos verba, como nos confirma a sentença de Cícero no arremate da consideração. Ver não só o que "se fala" (loquor nos reenvia ao domínio da elocutio), mas também o que pensa (sentio, por sua vez, nos reenvia ao domínio das "concepções", da inventio), como ainda os "porquês" de assim pensar (novamente inventio).

Passemos, agora, à consideração da segunda hipótese aventada (como ficou dito acima, não apoiar e deixar seguir, para ver até onde conhecem o que dizem, ou modificar um pouco, para ver se ainda reconhecem o que disseram, avançando e desdobrando o que foi dito): "[C] J'oy journellement dire à des sots des mots non sots. [B] Ils disent une bonne chose; sçachons jusques où ils la cognoissent, voyons par où ils la tiennent" (id. ibid.). Se antes se cobrava do juízo geral, as razões anteriores implicadas em sua formulação, o que se exige agora, por um lado, são seus desdobramentos e conseqüências, por outro, que se saiba o viés por onde é tomada e que, mudadas suas feições, ainda se a reconheça. Montaigne, primeiro, insiste um pouco mais em que não se deve apoiar ("ayder", "preter la main") quem as avançou, visto que não "possuem" "esta bela razão", apenas "guardam-na", tendo-a produzido "ao acaso e às apalpadelas": 
"[B] [...] Nous les aydons à employer ce beau mot et cette belle raison qu'ils ne possedent pas; ils ne l'ont qu'en garde: ils l'auront produicte à l'avanture et à tastons; nous la leur mettons en credit et en pris. Vous leur prestez la main. A quoy faire? Ils ne vous en sçavent nul gré, et en deviennent plus ineptes. Ne les secondez pas, laisses les aller: ils manieront cette matiere comme gens qui ont peur de s'eschauder; ils n'osent luy changer d'assiete et de jour, ny l'enfoncer." (id. ibid.)

Como se vê, Montaigne instrui, primeiro, que se os deixe caminhar sozinhos, sem conduzi-los, observando apenas sua maneira temerosa de "manejar" a matéria, cujas "feições" e "disposições" não ousam mudar, nem cujo sentido ousam "aprofundar". Para, em seguida, instruir, que se mudem estas feições para ver como se comportam: "[B] [...] Croslez la tant soit peu, elle leur eschappe: ils vous la quittent, toute forte et belle qu'elle est. Ce sont belles armes, mais elles sont mal emmanchées". (id. ibid.)

Caso contrário, ou seja, se vier a "esclarecer e confirmar" o que disseram, apreendem e roubam a "interpretação", alegando que Ihes faltava somente linguagem:

"[...] si vous venez à les esclaircir et confirmer, ils vous saisissent et derobent incontinent cet avantage de vostre interpretation: C'estoit ce que je voulois dire; voylà justement ma conception; si je ne l'ay ainsin exprimé, ce n'est que faute de langue." (id. ibid.)

Já se entrevê que nosso autor acusa-os, um tanto alterado com a "tolice" implicada no seu comportamento, de que falham na concepção da matéria, das coisas, mas argumentam com a falta de "palavras". Seu erro, não confessado, é de fundo, embora se exprima na forma "tola" de procederem. Aliás, como vimos ao tratar o problema da "ordem", a "forma" se ordena pela força com que se prende às matérias, nunca por apego ao formalismo vazio da lógica ou do labor com as palavras. Outra vez nos deparamos com a constante lição retórico-poética de subordinar os verba às res.

O prosseguimento atesta o quão impiedosa acaba por se tornar esta convivência e conversação com o "tolo", já que não se admite que a conference 
assuma o lugar da "didática", segundo postulava o "dogma de Hegesias", e que passe à "instruir" os "esprits mal rengés" em sua "soberba estupidez":

"[B] [...] II faut employer la malice mesme à corriger cette fiere bestise. [C] Le dogme d'Hegesias, qu'il ne faut ny haïr ny accuser, ains instruire, a de la raison ailleurs; mais icy $[B]$ c'est injustice et inhumanité de secourir et redresser celuy qui n'en a que faire, et qui en vaut moins. J'ayme à les laisser embourber et empestrer encore plus qu'ils ne sont, et si avant, s'il est possible, qu'en fin ils se recognoissent." (id. ibid.)

O exercício "maiêutico" - uma vez que ainda se trata de proporcionar um "reconhecimento", de fazer reconhecer a inépcia e a impertinência, de trazer à luz, num certo sentido - que aqui aflora não retém nada da generosidade que demonstrava no círculo restrito dos amigos ao corrigi-los ou por eles ser corrigido, pois não dispensa nem sequer a "malícia" e o "ódio", e deixa os interlocutores ineptos "atolarem-se" ("embouber") e "enredarem-se" ("empestrer") mais do que já se encontram atolados e enredados. Mas, as razões destes maus-tratos, revelam-se prontamente:

"[B] [...] La sottise et desreglement de sens n'est pas chose guerissable par un traict d'advertissement. [C] Et pouvons proprement dire de cette reparation ce que Cyrus respond à celuy qui le presse d'enhorter son ost sur le point d'une bataille: que les hommes ne se rendent pas courageux et belliqueux sur le champ par une bonne harangue, non plus qu'on ne devient incontinent musicien pour ouyr une bonne chanson.Ce sont apprentissages qui ont à estre faicts avant la main, par longue et constante institution. [B] Nous devons ce soing aux nostres, et cette assiduité de correction et d'instruction" (id. ibid.)

Delegada à "longa e constante" educação ("institution") que os pais dispensam aos filhos, a formação do "senso" se vê deslocada do ambiente da conversação montaigneana. Ela não é a ocasião das primeiras instruções, mas supõe, para o seu melhor e mais efetivo exercício, homens prontos e aptos, senhores de seus meios, formados desde a infância para o exercício autônomo de discernimento e julgamento. Não homens perfeitos e irrepreensíveis do ponto de vista da moralidade, mas de entendimento sólido e conscientes de seus próprios limites: em suma, "des testes bien faictes". O que supõe o 
esforço e o exercício prolongado que neles forjou tais disposições para bem julgar, corrigir e aceitar as correções. Arengar os soldados na iminência da batalha, ou ensinar o músico só por fazer ouvir uma boa canção, não adianta para alcançar os resultados visados pela institution, como reforça o comentário aposto ao passo comentado; a manière não se adquire pela advertência. Não basta ser avisado da tolice e do desregramento de senso, para que se dissipem. O reconhecimento de que se é tolo, não aproveita para sua correção, visto que o regramento, a maneira, a suffisance dependem de instrução e exercício demorados. O desenvolvimento da capacidade intelectual que estas noções representam, não se faz pelo mero aviso pontual, sendo antes capacidades que precisam ser desenvolvidas e mesmo forjadas na constância do exercício, supondo, portanto, que nas múltiplas experiências, o entendimento e o julgamento se empenhem em compreender e discriminar, em se ordenar.

O que Montaigne recusa, por fim e acima de tudo para o regime de sua conference, é a postura professoral que recua e começa a "pregar" ("prescher") a um "primeiro passante", para corrigi-lo, ou tenta disciplinar sua inépcia e ignorância - abecedária, diga-se - na esperança de forjar-lhes o entendimento e o juízo reto. Como peremptoriamente afirma: "[C] Mon humeur n'est propre, non plus à parler qu'à escrire, pour les principians". Nem nas conversações, nem no livro, que em grande medida assimila o Ensaísta às conversações, ele aceita falar ao tolo no intuito benévolo de lhe curar a tolice.

Em suas considerações finais deste movimento, retorna à questão da irritação diante da "tolice" dos "esprits mal rengés", a que antes respondera, como vimos, de modo um tanto oblíquo e evasivo, no passo em que acusava em si e reconhecia o defeito de irritar-se com o tolo. As novas razões que aduz, diferentemente das apresentadas antes, enraízam-se no comportamento "seguro" e "safisfeito" do próprio tolo: "[B] [...] Au demeurant, rien ne me despite tant en la sottise que dequoy elle se plaist plus que aucune raison ne se peut raisonnablement plaire" (id. ibid.). O que irrita ("despiter") na tolice é seu contentamento sem razão. Segurança e satisfação impossíveis para o homem prudente, que hesita e nunca está contente em seus julgamentos e razões. A queixa de Montaigne mostra o limite que a razão, razoavelmente, reconhece em si mesma, e que a tolice, em seu contentamento cego, não vê. O tolo não 
se sabe tolo, enquanto o homem verdadeiramente de senso sabe de sua fragilidade e fraqueza, da fragilidade de sua "prudência", e lamenta esta infelicidade: " $[\mathrm{B}]$ C'est mal' heur que la prudence vous defend de vous satisfaire et fier de vous et vous en envoye tousjours mal content et craintif là où l'opiniastreté et la temerité remplissent leurs hostes d'esjouissance et d'asseurance" (id. ibid.). A superioridade acaba se traduzindo em desvantagem para o homem de senso, lá onde justamente ele supera o tolo: no discernimento e reconhecimento de que suas opiniões e posições nunca estarão tão bem fundadas e seguras a ponto de que não tema sofrer um revés. O que ele vê, em sua não obstinação, em seu anti-dogmatismo, no saber que tem de seu não saber, é exatamente o que o ardor de opinião e a obstinação das "hostes" de tolos em seu "regozijo e segurança" não percebem, e por isso, retornam "tousjours du combat plains de gloire et d'allegresse". Pior ainda, sua confiança excessiva e arrogante ("outrecuidance") ao falar e seu semblante alegre ("gayeté de visage") Ihes garante a vitória por parte da assistência, "comumente fraca e incapaz de julgar e discernir as verdadeiras vantagens".

\subsection{As "agudezas" e ditos "espirituosos"}

Montaigne mescla à sua discussão uma breve menção sobre um outro "exercício", menos "sério" que o anterior, mas não menos "agudo e engenhoso", nem menos "proveitoso": "Pouvons nous pas mesler au tiltre de la conference et communication les devis pointus et coupez que l'alegresse et la privauté introduict entre les amis, gossans et gaudissans plaisemment et vifvement les uns les autres?" (id. ibid.). Os "devis pointus et coupez" ("falas agudas e cortantes") a que alude aqui, e que inscreve no contexto alegre e privado das amizades, o qual enseja que, na "conversa e comunicação" os amigos "gracejem uns com os outros e gozem uns dos outros prazenteira e vivamente", refere os ásteia e as urbanidades, portando no riso e na vivacidade de espírito que insere na convivência e entretenimento "familiar" um espectro amplo de matizes que vão dos gracejos e das facécias e ditos agudos e espirituosos, passando pela ironia até o sarcasmo em toda sua mordacidade. São de três ordens as considerações que faz: 1) quanto a produção das 
"agudezas", 2) quanto ao decoro de sua "recepção" e 3) quanto à finalidade e utilidade delas para a disciplina de entre-correção instaurada pela conference.

Quanto à produção, Montaigne prende tal exercício mais à sua "gayeté naturelle" e ao "engenho", do que propriamente a regras codificadas de sua produção, já que assentam mais na "presteza e prontidão de espírito" que captura feliz e oportunamente as ocasiões para surpreender e produzir o riso: "Pour mon regard, j'y apporte plus de liberté que d'esprit, et y ay plus d'heur que d'invention". (id. ibid.) Nisto de "aportar mais liberdade e felicidade" há uma discreta confissão de quem falha ao desconhecer as vias de sua "invenção" pelo espírito, e produzi-las mais pelo engenho do que pela arte.

Do ponto de vista da recepção ("souffrance"), no entanto, se diz "perfeito", porque "suporta a revanche", mesmo áspera e indiscreta, sem alteração. Quando sofre tais investidas sem ter com que revidar "bruscamente" no momento ("sur le champ"), não responde à espetada recebida de maneira tediosa e frouxa, "tirante à obstinação". Sem resposta, remete ao futuro sua vingança. Ao contrário, nota que muitos mudam a "fisionomia" ("visage") e a "voz" ("voix") quando "Ihes falta força", ou seja, quando não encontram resposta conveniente e igualmente aguda para contra-atacar imediatamente, encolerizando-se, o que não só lhes rouba a oportunidade de vingança, como expõe-lhes a "fraqueza e impaciência".

Por fim, a utilidade: "[B] [...] En cette gaillardise nous pinçons par fois des cordes secrettes de nos imperfections, lesquelles, rassis, nous ne pouvons toucher sans offence; et nous entre-advertissons utillement de nos deffauts". Talvez o ponto mais interessante, pois para exigência de entre-correção da conference, o elemento de gracejo e riso introduzido por esta "gaillardise" na convivência e comunicação, isto é, o tom de brincadeira e graça, "plaisant et vif", atenuam e abrandam a possível ofensa que uma dura advertência e acusação poderiam provocar, se feitas num tom puramente sério ou assentado ("rassis"). Assim, o reparo pode "pinçar" profundamente "cordas secretas das nossas imperfeições", "tocá-las" sem ofender. È como se a seriedade das repreensões fosse relevada pelo tom em que são feitas, quando de fato devem ser levadas muito a sério. 


\subsection{O juízo sobre a própria obra}

"Au reste, quand je veux juger de quelqu'un, je luy demande combien il se contente de soy, jusques où son parler ou sa besongne luy plaist" (id. ibid.). Chegamos, finalmente, às últimas advertências para o exercício da conference explanadas por Montaigne, antes de tocarmos no epílogo em que ilustra, lendo as Histórias de Tácito, uma "conversa" efetiva. Elas concernem também ao que nos ocupou em todo o segundo desenvolvimento do De l'art de conferer. Com efeito, ainda agora se trata da avaliação da suffisance do interlocutor. A estratégia descrita, diferentemente das prescritas anteriormente para as suffisances d'apparences e para as suffisances estrangeres, interrogam diretamente o homem a ser avaliado em seu "contentamento consigo" e no prazer que seu falar ou sua obra lhe proporcionam. Não é mais uma avaliação que se faz a partir da desconfiança diante dos indícios apresentados pelas aparências externas ou a partir da tentativa de "manejo" das matérias emprestadas, é o próprio sujeito que, em se julgando e às suas manifestações e obras, testemunha da sua capacidade e da estatura de sua "alma".

Para isso, é preciso afastar imediatamente as escusas de praxe de que o trabalho não está bem acabado, seja porque foi feito por bricandeira, seja porque às pressas e não revisto depois:

"[B] [...] Je veux eviter ces belles excuses: Je le fis en me jouant;

Ablatum mediis opus est incudibus istud;

je n'y fus pas une heure; je ne l'ay reveu depuis. - Or, fais-je, laissons donc ces pieces, donnez m'en une qui vous represente bien entier, par laquelle il vous plaise qu'on vous mesure. Et puis: Que trouvez vous le plus beau en vostre ouvrage? Estce ou cette partie, ou cette cy? la grace, ou la matiere, ou l'invention, ou le jugement, ou la science?" (id. ibid.)

Mais uma vez, o texto imita a forma de um diálogo, no qual Montaigne pressiona e desafia um adversário anônimo, primeiro, pedindo-lhe que descarte as peças "inacabadas" e "mal limadas", retiradas dele enquanto estavam na "forja" (mediis incudibus), e mostre uma que o represente "bem 
inteiro", pela qual se lhe apraza ser medido; depois, se voltando para as partes ("graça", "matéria", "invenção" etc.) das obras acabadas, interroga quais dimensões do opus lhe agrada mais. A justificativa do expediente nos é fornecida na continuação:

"[B] [...] Car ordinairement je m'aperçoy qu'on faut autant à juger de sa propre besongne que de celle d'autruy; non seulement pour l'affection qu'on y mesle, mais pour n'avoir la suffisance de la cognoistre et distinguer. L'ouvrage, de sa propre force et fortune, peut seconder l'ouvrier outre son invention et connoissance et le devancer." (id. ibid.)

A dificuldade apontada não é tanto a da "afeição" ("affection") que distorce o juízo sobre as próprias obras, quanto a da própria incapacidade de "conhecê-la e distingui-la", de conseguir discernir e julgar os pontos fortes e fracos, as partes boas e as más. Montaigne lembra que a obra, como resultado, pode comportar um "excesso" de qualidades que ultrapassa, curiosamente, o efeito que visava, em seu labor e em sua habilidade - em sua "invenção e conhecimento" -, quem a planejou e produziu. O artífice se vê superado pela obra que fez vir à luz, obra que ao sair de suas mãos já não lhe pertence, que não mais controla e que por sua "força e fortuna" pode ir além dele. Ainda neste ponto podemos estar enganados sobre o valor do "artesão" ("ouvrier"), avaliando-o mal a partir da força que tem seu trabalho, e que, paradoxalmente, pode não se dever a ele. Se o interrogamos visando que avalie sua própria obra, testamos se o que diz dela corresponde ao que ela vale. No fundo, o que se testa é se a obra pertence mesmo ao obreiro, ou se a virtude não the vem novamente de empréstimo. E relativizando modestamente sua própria "força", Montaigne afirma a dificuldade que experimenta ao julgar o valor de seus Ensaios: "[B] [...] Pour moy, je ne juge la valeur d'autre besongne plus obscurement que de la mienne: et loge les Essais tantost bas, tantost haut, fort inconstamment et doubteusement" (id. ibid.).

A seqüência dissocia claramente opus e artifex, o que confirma a necessidade de sondar a correspondência de forças, a adequação da vis do autor e das virtutes da obra, sempre antes de julgá-lo e honrá-lo. 
"[B] [...] II y a plusieurs livres utiles à raison de leurs subjects, desquels l'autheur ne tire aucune recommandation, et des bons livres, comme des bons ouvrages, qui font honte à l'ouvrier. J'escriray la façon de nos convives et de nos vestemens, et l'escriray de mauvaise grace; je publieray les edits de mon temps et les lettres des Princes qui passent és mains publiques; je feray un abbregé sur un bon livre (et tout abbregé sur un bon livre est un sot abregé), lequel livre viendra à se perdre, et choses semblables. La posterité retirera utilité singuliere de telles compositions; moy, quel honneur, si n'est de ma bonne fortune? Bonne part des livres fameux sont de cette condition." (id. ibid.)

Montaigne reata a partir deste ponto uma discussão que aflorara no ensaio no momento em que distinguia o sentido mais profundo da experiência, digerida e destilada, que opunha à simples e mera "história das práticas". Com efeito, lá nos falava dos numerosos historiadores, cujos livros - bons e úteis por seu registro de "belas e louváveis instruções" fornecidas "du magasin de leur memoire" -, não serviam de critério para julgar do valor daqueles "recitadores e recolhedores". Precisamente o que está, mais uma vez - se não sempre -, em questão em nosso capítulo: a busca de critérios que permitam julgar sobre o caráter dos homens. No passo acima citado, vemos como separa a utilidade e bondade de obras ("livres", "ouvrages") - como as dos editos e cartas dos príncipes, ou o "abregé" - sempre tolo - de um bom livro que vem a perder-se - em razão de seus "assuntos" ("subjects"), da "recommandation" que delas poder-se-ia obter. Muitas até "fazem vergonha" ao "ouvrier" (como escrever sobre o modo de vestir-se, ou o modo de comportarem-se os convivas), apesar de sua utilidade. Há obras úteis, portanto, de duas condições. De umas, nas matérias variadas que podemos encontrar em "tais composições", embora úteis e louváveis, nem sempre autores obtêm consideração pública; e muitas até constrangem. Boa parte dos livros famosos são assim, segundo ele. De outras, sim, obtém-se a consideração. Vemos que as qualidades das obras não vão pari passu acompanhando as dos artífices. Mas a distinção enseja uma observação mais geral sobre a tarefa de escrever. Montaigne não só lembra e repisa, com ela, o desprezo pela transitividade do labor dos artesãos, que são reconhecidamente úteis pelo resultado do trabalho e do esforço que legam à posteridade por meio de suas obras, mas que sofrem a pecha de "servir", de pôr-se a serviço de um outro, de atender, em seu 
trabalho, a necessidades alheias e estranhas a um "honnete homme". Mas ainda evidencia um outro traço e aspecto desta lide: o da ambição ligada a tais projetos de publicações, cuja vanidade e desejo de glória acusa. Não só questiona o "comércio" dos pedantes como a tolice dos que se fazem, sendo homens de condição livre, escritores de livros vãos. Não que chegue radicalmente a excluir toda poíesis, ele que se dedica em seu ócio e retiro para o seio das Musas a confecção de um livro, em nome de uma práxis que não transige com as produções. A intransigência é com a lide servil ou fútil no domínio das letras, ciências, artes.

Mas, voltando, se é preciso separar a obra do artífice, despi-lo desta vestimenta de discurso para sondar-Ihe as qualidades, não se podem tomar os "assuntos", os "argumentos", as "sentenças" e "ditos" inseridas em sua obra precipitadamente como seus e de sua produção. Nem sempre cabe a ele a "invenção" daquilo que escreveu. De novo a questão do empréstimo e a correlata idéia de autoria. Montaigne discerne, claramente, dentro da vasta tradição letrada de que participa, o valor dos contributos das auctoritates e o valor menor dos escritores e compiladores que só fazem re-propor e reproduzir, com maior ou menor grau de compreensão e de digestão, as lições dos autores que freqüentam e pilham. É o que exemplifica com sua experiência de leitura de um historiador do seu tempo, Philippe de Comines. Tendo notado nele uma "expressão" ("mot") como não vulgar, e depois, tendo-a reencontrado em Tácito, Sêneca e Quinto Cícero, conclui que o louvor cabe à invenção e não ao homem. Observar uma expressão como invulgar não basta para levar ao elogio do autor, é preciso discernir se nãoa tomou emprestado de outrem, pois,

"[B] Le subject, selon qu'il est, peut faire trouver un homme sçavant et memorieux; mais pour juger en luy les parties plus siennes et plus dignes, la force et beauté de son ame, il faut sçavoir ce qui est sien et ce qui ne l'est point, et en ce qui n'est pas sien combien on luy doibt en consideration du chois, disposition, ornement et langage qu'il y a fourny." (id. ibid.)

A preocupação aqui é a de estabelecer critérios que permitam separar um homem "sçavant et memorieux" de um homem que verdadeiramente seja "suffisant". Para julgar não basta considerar a matéria 
("le subject") enquanto tal. Para julgar num homem "as partes mais suas e mais dignas, a força e beleza de sua alma", fazem-se necessárias distinções entre o que lhe é próprio e o que lhe é alheio, e, depois, no domínio do que lhe é alheio discernir as contribuições próprias quanto à "escolha, disposição, ornamento e linguagem" que ele forneceu à matéria. Pois, Montaigne se questiona sobre os casos em que se tomou emprestada matéria, mas em que se piorou a forma. Tais critérios pressupõem claramente erudição e especialização nas letras: daí a consideração final do passo, em que alude ao constrangimento de terem de recorrer, os que são pouco versados nos livros, antes de fazer um elogio a uma "bela invenção" ou "algum forte argumento" a algum "sçavant" que os instrua sobre se é própria ou estranha ao poeta novo ou pregador "esta peça"53.

\subsection{Epílogo: a leitura-conversa da "História de Tácito"}

Resta fazer um comentário do sentido do movimento que fecha o capítulo. Como notou já Yves Delegue, Montaigne transcreve neste final o exercício de juízo a que foi levado pela leitura dos Anales de Tácito, e isto o encaminha para considerações sobre a sua prática de escritor ${ }^{54}$.

Com efeito, o que se nota é que o Ensaísta - neste exercício excepcional para ele, como nos diz, pois leu de uma vez (cf. id. ibid.: "Je viens de courre d'un fil"), quando afirma não empregar mais de uma hora seguida na leitura - examina a obra como quem conversa com seu autor, notando seus pontos fracos e fortes, anotando as discordâncias e acordos, ao examinar com minúcia certos aspectos da obra (as razões e argumentos que emprega, seu estilo e, sobretudo, seu julgamento) e ao tentar reconhecer o homem que está por trás dela. Faz um elogio aberto do gênero de história que escreve, reconhecendo nos juízos do autor sobre sua época uma descrição da sua. $E$ ainda no que respeita ao gênero, examina a sua ousadia em transcrever os testemunhos, assentindo, elogiosamente, ao seu respeito pelo "exemplo e

\footnotetext{
${ }^{53}$ Curiosamente, o homem que se especializa nas letras deve aqui ser consultado previamente ao louvor, ele que em muitos momentos é desqualificado. Neste passo mesmo, o homem "sçavant et memorieux", que pode, aliás, estar por trás de uma bela discussão, não é digno de louvor, por não se tratar de pessoa que traga contributo, que seja propriamente um "auctor". É ele, no entanto, que é capaz de, em seu saber, discernir o próprio do alheio na invenção e, portanto, assinalar quem pode e deve ser louvado, quem não.

${ }^{54}$ Cf. Delegue, Y., op. cit., p. 34.
} 
dever de todos os bons historiadores", sendo o dever deles manter o registro das "ocorrências públicas", dentre as quais se encontram os "rumores e opiniões poupulares" (cf. id. ibid:: "Ils tiennent registre des evenements d'importance; parmy les accidens publics sont aussi les bruits et opinions populaires. C'est leur rolle de reciter les communes creances, non pas de les regler"), "devolvendo-nos a história mais segundo recebem do que segundo estimam".

E termina por medir-se com Tácito neste ponto, "conferindo" sua prática com a dele:

"[B] [...] Moy qui suis Roy de la matiere que je traicte, et qui n'en dois conte à personne, ne m'en crois pourtant pas du tout: je hasarde souvent des boutades de mon esprit, desquelles je me deffie, $[\mathrm{C}]$ et certaines finesses verbales, dequoy je secoue les oreilles; [B] mais je les laisse courir à l'avanture. [C]Je voys qu'on s'honore de pareilles choses. Ce n'est pas à moy seul d'en juger. Je me presente debout et couché, le devant et le derriere, à droite et à gauche, et en tous mes naturels plis." (id. ibid., p. 943) 


\section{CONSIDERAÇõEs FinaIS}

Terminado nosso percurso, cumpre, nestas considerações finais, repassar brevemente os seus passos, e reiterar os pontos que julgamos importantes em nossa leitura.

Vimos, em primeiro lugar, que Montaigne trata do tema da "conversação" nos expondo antes os defeitos a evitar que as qualidades a imitar, ou seja, a instrução apresentada é toda ela par contrarieté. A boa conference surge e toma forma, então, sempre por oposição aos seus avessos: a obstinação, o espírito excessivamente combativo e erístico, a adulação, o pedantismo e a tolice. Assim, menos do que uma exposição das regras para o exercício do pensamento, o que nos é oferecido é um conjunto de advertências que o balizam e orientam, voltando à atenção para os erros a evitar. A partir deles é que se desenham as qualidades da "maneira" (a "ordem", a "prudência", a suffisance) e que se esboça a conduta apta nesta "justa" entre amigos, que, ao mesmo tempo, rivalizam e cooperam, na busca que empreendem em comum.

Vimos, também, como o "solo" cético e anti-dogmático a partir do qual Montaigne erige as condições para o exercício da conference, ao encerrar o homem numa "escole d'inquisition", desloca as competências de um saber das "matérias" para um aptidão da "forma" e conduta regrada; converte, enfim, para o plano da "maneira" a atenção que ele requer. O que importa, então, passa a ser não mais a "captura da presa", mas a boa e bela "condução da caçada"; não mais alcançar um discurso verdadeiro sobre as coisas, mas a ordem, a prudência e a suffisance ao sondá-las neste rude embate amigável que é a boa conference.

No entanto, tal "conversão" não significa, para Montaigne, apegar-se à qualquer formalismo. Nossa análise procurou mostrar que esta reorientação para a maneira, recusando uma lide com os saberes calcada na memória e nos empréstimos, bem como nos puros procedimentos codificados nas artes ${ }^{55}$

\footnotetext{
${ }^{55}$ Benedicte Boudou exprime, em seu artigo intitulado " $L$ 'accomplissement des Essais dan De l'art de conférer", de maneira apropriada este traço: "Moins qu' un code de la conversation, "De I'art de conferer" definit avec agressivité un "esbat" qui contest la scolastique et une rhétorique de l'affectation, tout comme diverses formes d'autorité et de faiblesse." (Cf. BLum, Claude
} 
seja os do cuidado com as palavras, seja os do apego às regras formais da disputa -, nos reenvia novamente para o cuidado com as próprias coisas (res). É pela própria articulação e encadeamento das concepções, a partir das conjunções e disjunções que o juízo nelas opera, que, por si só, a trama do discurso se ordena.

Não se entende mais, evidentemente, esta aplicação às coisas no sentido dogmático de uma apreensão de sua verdade - pois, opera-se aqui, como tentamos mostrar, no plano das "representações" (phantasiaî) -, mas no de um processo de assimilação e digestão, que exige avaliar o seu peso, inspecionar suas conexões, apropriando-se do seu sentido. Esta assimilação torna próprio o que era alheio, discernindo articulações que, embora exteriores ao que se teria como sua essência, impõem ordem ao discurso - a ordem inscrita nas concepções, e não vinda de fora através de preceitos - e dão pertinência ao tratamento das matérias. Montaigne exprime toda sua aversão às disciplinas lógicas, como meio seguro de condução do pensamento, e às Letras, ao anatemizar aqueles que se prendem exclusivamente aos cuidados com a "forma".

A idéia mesma de dar regras para o exercício do pensamento e a produção do discurso é recusada, pois, vincula-se já à inépcia do tolo, que desvirtua as qualidades tão enfaticamente apreciadas pelo Ensaísta neste que é o "mais frutuoso e natural exercício do espírito". Todo pensamento deve se pautar pelos "meios naturais" de um "são entendimento", estando na origem dos defeitos exibidos, por um lado, o dogmatismo, por outro, um formalismo vazio, fruto de uma relação servil e pedante com os saberes e as ciências. $O$ dogmatismo, sem dúvida, ele o afasta por meio da crítica cética do conhecimento, que combate a presunção de saber e habilita ao exame racional das opiniões sobre as matérias, sob o regime da contradição dos julgamentos. O pedantismo, ele o combate por meio de sua concepção de formação (institution), orientada toda ela para desenvolver a capacidade de julgamento, excluindo toda acolhida, pela memória e sem crítica, dos saberes de autoridade.

(Org.). Montaigne et Les Essais (1588-1988): Actes du congrès de Paris, janvier, 1988. Paris: Librairie Honoré Champion, 1990. p. 42). 
A conference montaigneana circunscreve, assim, uma "société et familiarité", que têm a si assinaladas duas finalidades: uma, de crítica das opiniões, outra, de correção moral dos amigos. Por um lado, então, a conference é poderoso instrumento para combater e destituir a presunção de saber; por outro, se presta, pelo espelhamento do vício na fala franca e corretora do amigo, a um ordenamento dos costumes. Montaigne parte de um diagnóstico da imperfeição humana no seu projeto e aspiração ao saber e à ação reta e justa, e podemos dizer que, num sentido geral, adverte para a presunção implicada nos projetos de conhecimento e de condução ordenada das coisas a partir de uma ciência. E em seu De l'art de conferer nos oferece, tal como bem exprimiu Marc Fumaroli, uma "arte de pensar na medida humana", de que os Ensaios são o constante exercício ${ }^{56}$. Este estudo, portanto, nos encaminha para o tratamento dos elementos centrais implicados na forma montaigneana do ensaio.

${ }^{56}$ FumAROLI, M., op. cit., p. XIII e p. XXVI-VII. 


\section{BIBLIOGRAFIA}

a) edições dos Ensaios:

Montaigne, Michel de. Les Essais. Éd. par P.Villey et V.-L. Saulnier. Paris: PUF-Quadrige, 1992, 3 vols. . Oeuvres Complètes de Montaigne. Textes établies par A. Thibaudet. Paris: Gallimard, 1962. (Bibliothèque de la Pléiade). . Ensaios. Trad. de Sérgio Milliet. São Paulo: Abril Cultural, 1980. (Col. Os Pensadores).

. Seleta dos Ensaios de Montaigne. Trad. de J. M. de Toledo Malta. Rio de Janeiro: José Olympio, s/d. (Col. Rubáiyát).

. Os Ensaios. Ed. de P. Villey em tradução de Rosemary Costhek Abílio. São Paulo: Martins Fontes, 2000 e 2001. 3 v.

b) fontes primárias:

ARIStóteles. Rhétorique. Texte traduit par M. Dufour. Paris: Les Belles Lettres, 1967. $3 \mathrm{t}$.

Cicero. Rhetorica. Recognovit brevique adnotatione critica instruxit A. S. Wilkins. 3 ed. Oxford: Oxford University Press, 1988. t. 1 e 2.

Horácıo. A Arte Poética de Horácio. Trad. Dante Tringali. São Paulo: Musa Editora, 1994. (Ed. bilíngüe.)

QuINTILIEN. Institution Oratoire. Texte établie et traduit par Guy Achard. Paris: Les Belles Lettres, 1975-80. $7 \mathrm{t}$.

Rhétorique à Herennius. Texte établie et traduit par Guy Achard. Paris: Les Belles Lettres, 1989.

Seneca. Lettere a Lucilio. Introduzione di Luca Canali. Traduzione e note di Giuseppe Monti. 4 ed. Milano: Biblioteca Universale Rizzoli, 1991.

Sextus EmpIRIcus. Outlines of Pyrrhonism. Transl. Julia Annas and Johnathan Barnes. Cambridge University Press, 1994.

c) bibliografia complementar (comentadores):

c.1. estudos diretamente referidos ao tema:

AdAm, Colette-Chantal. Au siècle des Essais: Quelle conférence pour Montaigne? In MAтHIOT, Pascal et alii. Lectures de "L'art de conférer" de 
Montaigne. Thème: L'Ironie. Paris: Librairie Euphorion, Librairie Eugène Belin, 1980. p. 21-46. (Coll. Oeuvres et thèmes.)

. Étude de texte: Montaigne, Essais, III 8. In: Écoles des Lettres, Paris, LXXIV, n. 5, p. 13-17, 15 nov. 1982.

BaLmas, E. "Rhétorique et originalité chez les poètes de la Pléiade". In: Gray, F. et TeTEL, M. Textes et intertextes: études sur le XVle siècle, pour Alfred Glauser. Paris: Nizet, 1979.

Beaujour, Michel. Miroirs d'Encre: rhétorique de l'autoportrait. Paris: Seuil, 1980.

Bellenger, Y. "Paradoxe et ironie dans les Essais de 1580". In: Jones-Davis, M. T. (org.) Le Paradoxe au Temps de la Renaissance. Paris: Jean Touzot Librairie-Editeur, s.d., p. 9-22.

Beugnot, Bernard. "Un aspect de la réception critique: la citation". In: Oeuvres et Critiques, 1, 1976, p. 5-19.

. "Dialogue, entretien et citation à l'époque classique". In: Revue Canadienne de Littérature Comparée, 1976, p. 39-40. . "Style ou styles épistolaires?". In: RHLF, 78, 1978, p. 939-57.

BoccazzI, Gaudenzio. "La Civil Conversazione: Montaigne et Stefano Guazzo". In: Montaigne et l'Italia. Actes du Congres Montaigne de 1991. Geneve: Slatkine, 1992 (col. Bibliotheque du Voyage en Italie, no. 38)

Boudou, Bénédicte. "L'accomplissement des Essais dans 'De l'Art de conférer"'. In: BLum, Claude (Org.). Montaigne et Les Essais (1588-1988): Actes du congrès de Paris (janvier 1988). Paris: Librairie Honoré Champion, 1990. p. 41-55.

BRUSH, Craig B. "Un autoportrait n'est pas une autobiographie". In: Oeuvres et Critiques. Revue internationale de la reception des oeuvres littéraires de langue française, VIII, 1-2, 1983.

BURT, E. S. "Poetic Conceit: the self-portrait and mirrors of ink". In: BLum, Harold. Michel de Montaigne's Essays. New York: Chelsea House Publ., 1987.

CAVE, Terence. The cornucopian text: problems of writing in the French Renaissance. Oxford: Clarendon Press, 1979.

Coleman, Dorothy. Montaigne, quelques anciens et l'écriture des Essais. Honoré Champion, 1995. 
. "Montaigne's text: Negligentia Diligens". In: Cambridge Procedings of the Cambridge Montaigne's Colloquium, 7-9 april 1988.

DéfauX, G. "Rhétorique et représentation dans les Essais: de la peinture de l'autre à la peinture du moi". In: Rhétorique de Montaigne - Bulletin de la Société des Amis de Montaigne (BSAM), 7ème. série, 1-2, 1985, p. 21-48.

Delegue, Yves. "De l'art de conferer (III, 8) ou de la 'sottise' ". In: Bulletin de la Société des Amis de Montaigne. 8ème. série. no. 29-30. Paris: Honoré Champion, 2003. p. 29-43.

Demers, Jeanne. "Les Essais, anti-rhétorique ou nouvelle rhétorique?". In: Montaigne et la Grèce, Actes du colloque de Calamata et de Messéne, presentés par K. Christodoulou. Paris, Aux Amateurs de Livres, 1990.

Demonet-Launay, M. L. "Art de conférer, art de raisonner" (III, 8). In: Charpentier, Françoise (Org.) Montaigne: Les derniers essais. Actes de la journée d'étude Montaigne. Paris: UER (Sciences de Textes et Documents), Université Paris VII, 1986. (Cahiers Textuel, 34/44, no. 2). P. 19-31

Duвoıs, Cl.-G. "L'approfondissement de la réflexion sur l'art d'écrire dans les Essais de 1588". In: Revue D'Histoire Littéraire de la France. 88ème année, no. 5. Sep-oct. Paris: Armand Colin, 1988

EHRLICH, Hélène-Hedy. Montaigne, la conscience et le language. Paris: Kliencksieck, 1972.

FumARoLI, Marc. "Montaigne et l'éloquence du for intérieur".In: Les formes brèves de la prose et le discours discontinu (XVIe-XVIle siècle). Paris: Vrin, 1984.

. L'âge de l'éloquence. Paris, Genebra: Droz, 1980.

. "O discurso do método de Montaigne". In: Pascal, Blaise. A arte de persuadir (precedida de $A$ arte da conferência de Montaigne). São Paulo: Martins Fontes, 2004. Prefácio.

GARAVINI, Fausta. Mostri e chimere. Montaigne, il texto e il fantasma. Milano:II Mulino, 1997.

. "Au sujet de Montaigne: de la Leçon à l'écriture du moi". In: Carrefour Montaigne: Quaderni del Seminario di Filologia Francese, n. 2. Éd. par J. Brody et alii. Pisa, Genève: Edizioni ETS, Slatkine, 1994. 
"Montaigne: L'exemplum et le phantasme". In: Le lecteur, l'auteur et l'écrivain Montaigne (1492-1592-1992), Actes du Colloque Internationale de Haifa, avril-mai, 1992. Éd. par I. Zingler. Paris: Honoré Champion, 1993.

Gray, Floyd. Le style de Montaigne. Paris: Nizet, 1958.

GreEne, Thomas M. The light in Troy: imitation and discovery in Renaissance Poetry. New Haven: Yale University Press, 1982.

GUERRIER, Olivier. "L'interne jurisdiction: l'essai comme exercice". In: Bulletin de la Société des Amis de Montaigne. 8ème. série. no. 29-30. Paris: Librairie Honoré Champion, 2003. p. 43-59.

HAMPTON, Tymothy. Writing from History: the rhetoric of exemplarity in Tasso, Montaigne and Cervantes. 1986. Tese - Princeton.

KRITZMAN, L. D. "Montaigne et la Nouvelle Rhétorique". In: Destruction/Découverte. Paris: French Forum, 1980.

LA CHARITÉ, Raymond. The concept of judgment in Montaigne. La Haye: Nijhoff, 1968.

LeAKE, R. E. Concordance des Essais. Genève: Droz, 1981.

Lestringant, Frank (éd.). Rhétorique de Montaigne. Paris: Honoré Champion,1985.

MAC KINLEY, Mary. Words in a corner. Studies in Montaigne's latin quotations. Lexington: French Forum Publications, 1981.

Mathieu-Castellani, G. Montaigne: l'écriture de l'Essai. Paris: PUF, 1988.

Матніот, Pascal. "L'ironie et le jeu". In: МАтніот, Pascal et alii. Lectures de "L'art de conférer" de Montaigne. Thème: L'Ironie. Paris: Librairie Euphorion, Librerie Eugène Belin, 1980. p. 85-109 (Coll. Oeuvres et thèmes.)

MORRISSEY, Robert. La rêverie jusqu'à Rousseau. Lexington: French Forum, 1984.

NAKAM, Géralde. "Montaigne, la Mélancolie et la Folie". In: Études montaignistes en hommage a Pierre Michel, par le concours de C. Blum et F. Moreau. Paris: Honoré Champion, 1984.

. Montaigne, la manière et la matière. Paris: Kliencksieck, 1992.

O'Brien, John. Montaigne et la Rhétorique. Paris: Honoré Champion Nouvelles, 1995. 
PÉrigot, Béatrice. "L'essai dans la filiation de la dispute médiévale?" In: Glaudes, Pierre (Org.). L'essai: métamorphoses d'un genre. Paris: Presses Universitaires de Mirail, 2002. p. 135-157. . Montaigne, "De l'art de conférer (III,8): de la dispute à l'Essai". In: Glaudes, Pierre (Org.). L'essai: métamorphoses d'un genre. Paris: Presses Universitaires de Mirail, 2002. p. 157-187.

QuINT, David. Origin and Originality in Renaissance Literature. New Haven: Yale University Press, 1983.

Ramos, Silvana de S. Análise do capítulo De l'art de conferer (Essais III, VIII), de Michel de Montaigne. Dissertação (Mestrado). FFLCH-USP. 2004.

Regosin, R. "Recent trends in Montaigne Scholarship: A post-structuralist perspective". In: Renaissance Quaterly XXXVII, I, 1984.

Rıgolot, F. Le texte à la Renaissance: Des Rhétoriqueurs à Montaigne. Genève: Droz, 1982.

RUdENT, François-Victor. La conversation de Montaigne; conference et philosophie. (col. Ouverture philosophique) Paris: Harmattan, 2001.

Samaras, Z. The Comic elements of Montaigne's Style. Paris: Nizet, 1970.

TÉTEL, Marcel. Stefano Guazzo: de deux conversations. In: TÉTEL, Marcel. Présences italiennes dans Les Essais de Montaigne. Paris: Librairie Honoré Champion, 1992. p. 11-29.

Tournon, André. “L'Essai: un témoignage en suspens”. In: Carrefour Montaigne: Quaderni del Seminario di Filologia Francese, n. 2. Éd. par J. Brody et alii. Pisa, Genève: Edizioni ETS, Slatkine, 1994.

THWEATt, Vivian. "L'art de conférer: Art des Essais, art de vivre". In: Romanic Review, 68. New York: Columbia University Press, 1977.

ZingueR, Ilana. "Les trois commerces ou Principes pour une Théorie de la Communication". In: Le Lecteur, L'Auteur et L'Écrivain: Montaigne 1492-15921992. Actes du Colloque International de Haifa. Avril-Mai 1992. Paris: Librairie Honoré Champion, 1993.

c.2. estudos gerais sobre os Ensaios:

AuERBACH, Erich. "L'Humaine Condition”. In: Mimesis: a representação da realidade na literatura ocidental. 4aㅡ ed. São Paulo: Perspectiva, 2001, p. 24976. (Col. Estudos). 
Cardoso, Sérgio. "O homem, um homem: do humanismo renascentista a Michel de Montaigne". In: Perturbador Mundo Novo. São Paulo, Escuta, 1992. . "Villey e Starobinski: duas interpretações exemplares sobre a gênese dos Ensaios". In: Kriterion, vol. 23, n. 86, ago/set, 1992.

Eva, Luiz A. Alves. Ceticismo e Paradoxo nos Ensaios de Montaigne. Tese (Doutoramento). FFLCH-USP, 1999.

FrIEDRICH, Hugo. Montaigne. Paris: Gallimard, 1968.

Poullloux, Jean-Yves. Lire les Essais de Montaigne.Paris: Maspéro, 1969.

Rendall, E. Distinguo: Reading Montaigne differently. Oxford: Clarendon Press, 1992.

SAYCE, Richard A. The Essais of Montaigne: a critical exploration. Londres: Weidenfeld and Nicolson, 1972.

SchAefER, David Lewis. The Political Philosophy of Montaigne. Ithaca, London: Cornell University Press, 1990.

Scoralick, A. Experiência e Moralidade no último dos Ensaios de Montaigne. Dissertação (Mestrado). FFLCH-USP. 2008.

Screech, Michael A. Montaigne et la mélancolie. Collection Littérature française du Moyen-Age et de la Renaissance. Paris: PUF, 1992.

StARobinskı, Jean. Montaigne em Movimento. São Paulo: Cia das Letras, 1993.

Theobaldo, M. C. Sobre o "Da educação das crianças": a nova maneira de Montaigne. Tese (Doutoramento). FFLCH-USP. 2008.

Tournon, André. Montaigne: la glose et l'essai. Paris: Honoré Champion, 2000.

. Montaigne en toutes lettres. Paris: Bordas, 1993.

ViLLey, Pierre. Les sources et l'évolution des Essais de Montaigne. Osnabrück: Otto Zeller, 1976. (reimpressão da 2a. edição de 1933. Paris: Librarie Hachette.)

c.3. obras coletivas:

ARgod-DutARD, Françoise (Org.). Des Signes au Sens: lectures du livre III des Essais. Journées d'études du centre Montaigne de Bordeaux. 14-15 novembre 2002. Paris: Librairie Honoré Champion, 2003 
Berven, Dikka (ed.). Montaigne - A Collection of Essays: a five-volume anthology of scholarly articles. New York, London: Garland Publishing, 1995.

Blum, Claude (Org.). Montaigne et Les Essais (1588-1988): Actes du congrès de Paris (janvier 1988). Paris: Librairie Honoré Champion, 1990. p. 41-55.

et Moreau, F. Études montaignistes en hommage a Pierre Michel Paris: Honoré Champion, 1984.

Brody, J. et alii. Carrefour Montaigne: Quaderni del Seminario di Filologia Francese, n. 2. Pisa, Genève: Edizioni ETS, Slatkine, 1994.

Cambridge Procedings of the Cambridge Montaigne's Colloquium, 7-9 april 1988.

Cameron, Keith; Willet, Laura (Orgs.). Le visage changeant de Montaigne. Paris: Librairie Honoré Champion, 2003.

Charpentier, Françoise (Org.) Montaigne: Les derniers essais. Actes de la journée d'étude Montaigne. Paris: UER (Sciences de Textes et Documents). Université Paris VII, 1986. (Cahiers Textuel, 34/44, no. 2). P. 19-31

Defaux, Gerard (ed.). Montaigne: Essays in Reading. Yale French Studies, number 64. New Haven: Yale University Press, 1983

Glaudes, Pierre (Org.). L'essai: métamorphoses d'un genre. Paris: Presses Universitaires de Mirail, 2002. p. 135-157.

Gray, F. et Tetel, M. Textes et intertextes: études sur le XVle siècle, pour Alfred Glauser. Paris: Nizet, 1979.

Jones-Davis, M. T. (org.) Le Paradoxe au Temps de la Renaissance. Paris: Jean Touzot Librairie-Editeur, s.d., p. 9-22.

Mathiot, Pascal et alii. Lectures de "L'art de conférer" de Montaigne. Thème: L'Ironie. Paris: Librairie Euphorion, Librerie Eugène Belin, 1980. p. 21-46. (Coll. Oeuvres et thèmes.)

Montaigne et la Rhétorique. Actes du Colloque de St. Andrews. 28-31 mars 1992. Paris: Librairie Honoré Champion, 1999 (Coll. Études Montaignistes) Montaigne et l'Italia. Actes du Congres Montaigne de 1991. Geneve: Slatkine, 1992 (col. Bibliotheque du Voyage en Italie, no. 38)

Montaigne et la Grèce, Actes du colloque de Calamata et de Messéne, presentés par K. Christodoulou. Paris, Aux Amateurs de Livres, 1990. 
ZINGLER, I. Le lecteur, l'auteur et l'écrivain Montaigne (1492-1592-1992), Actes du Colloque Internationale de Haifa, avril-mai, 1992. Paris: Honoré Champion, 1993. 